\title{
Emancipated entrepreneuring in the nascent commercial spaceflight industry: Authoring ecosystems by Branson, Diamandis, and Musk
}

\author{
Ewan Reid
}

A thesis submitted to the Faculty of Graduate and Postdoctoral Affairs

in partial fulfillment of the requirements for the degree of

$$
\text { Master of Applied Science }
$$

in

Technology Innovation Management

Carleton University

Ottawa, Ontario

Copyright @ 2018 Ewan Reid 
Emancipated entrepreneuring in the nascent commercial spaceflight industry: Authoring ecosystems by Branson, Diamandis, and Musk. Copyright (C) 2018 Ewan Reid

\section{Abstract}

The emancipatory perspective on entrepreneuring examines the activities undertaken by entrepreneurs to bring about change. Business ecosystems are a mode of organizing economic production that differs from markets and organizational hierarchies, and is increasingly associated with collaborative innovation, opportunities for technology entrepreneurship, and rapid technological progress. This thesis examines how business ecosystems feature in the emancipation actions of entrepreneurs in the commercial spaceflight industry. The research design is a case-based event study of three entrepreneurs and their space ventures: Sir Richard Branson and Virgin Galactic, Peter Diamandis and XPRIZE, and Elon Musk and SpaceX. Results show that business ecosystems can be emancipating - as a means for escaping constraints, in the authoring activities to enact change, and in making declarations to mobilize support, manage interpretations, and motivate change from others. Contributions include a formal operational specification for event studies using the emancipation perspective that can be applied in other field settings. 
Emancipated entrepreneuring in the nascent commercial spaceflight industry: Authoring ecosystems by Branson, Diamandis, and Musk. Copyright (C) 2018 Ewan Reid

\section{Acknowledgments}

I would like to thank Judy Senecal of Carleton's MacOdrum Library for her introduction to NVivo and help procuring the source material in a format that could be imported to NVivo.

I would like to thank Emily Byron of the Technology Innovation Management department for her continual support and helping me to navigate the waters of graduate school.

Most importantly I would like to thank Professor Steven Muegge for his critical contributions, ideas, and academic guidance for this thesis in addition to personal support and encouragement throughout my career at Carleton University, without which this thesis could not have been completed. 
Emancipated entrepreneuring in the nascent commercial spaceflight industry:

Authoring ecosystems by Branson, Diamandis, and Musk. Copyright (C) 2018 Ewan Reid

\section{Table of contents}

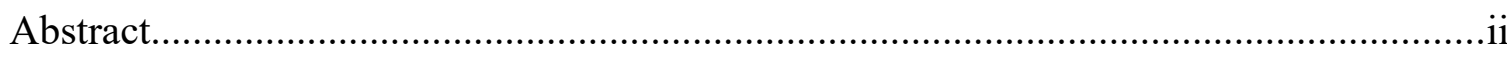

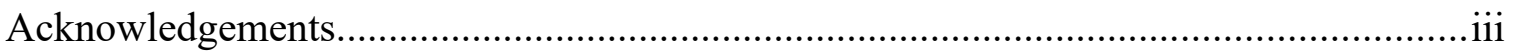

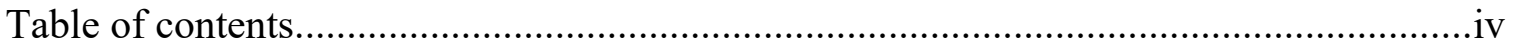

List of tables.................................................................................................... vii

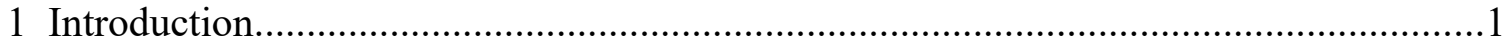

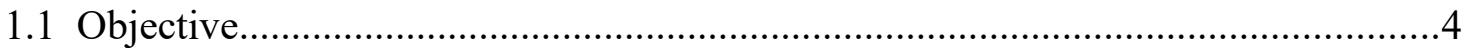

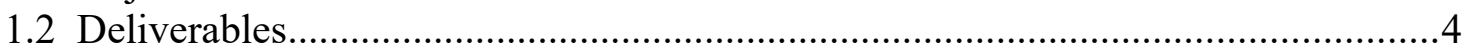

1.3 Relevance

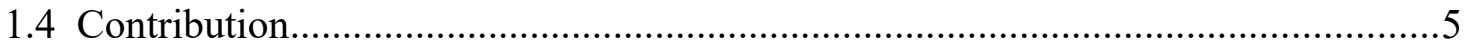

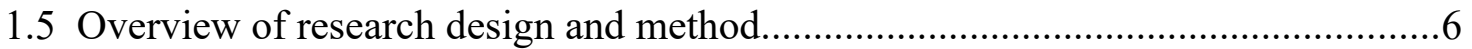

1.6 Organization of the document........................................................................ 7

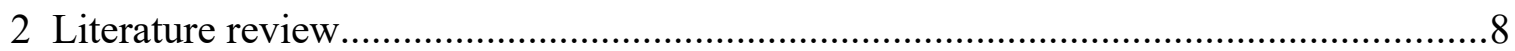

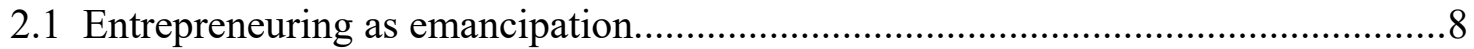

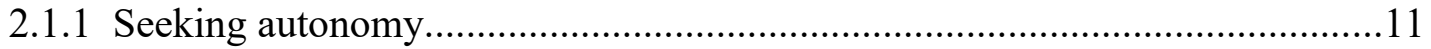

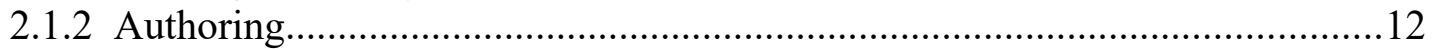

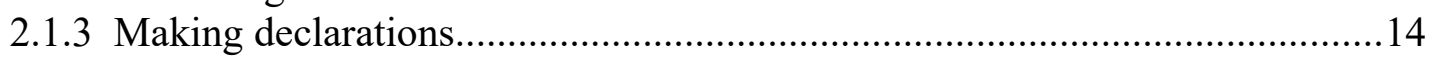

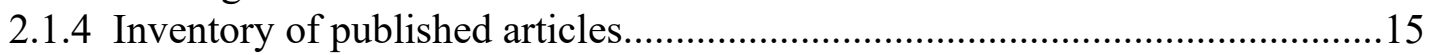

2.1.5 Empirical studies of entrepreneuring as emancipation............................... 17

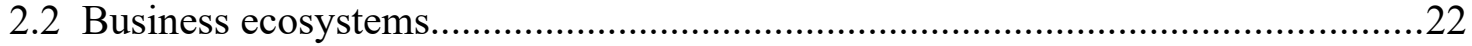

2.2.1 Business ecosystems as an organizational form..........................................24

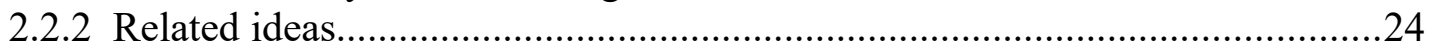

2.2.3 Classical view of markets and hierarchies..................................................28

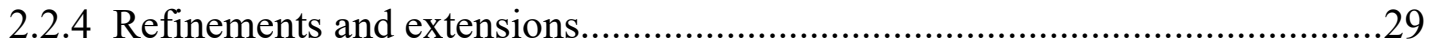

2.3 Linking business ecosystem and emancipation constructs...............................34

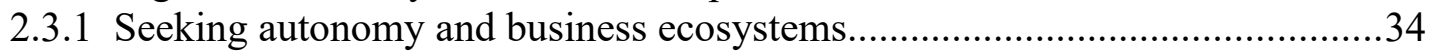

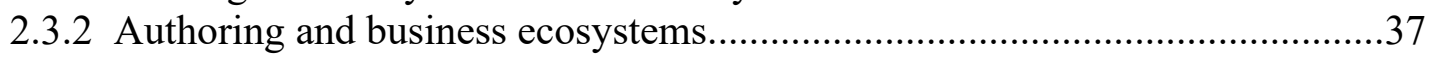

2.3.3 Making declarations and business ecosystems............................................40

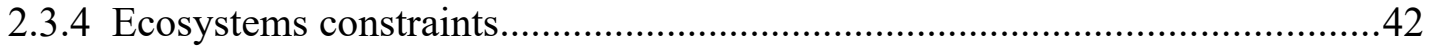

2.4 Summary and synthesis of key findings from the literature..............................43

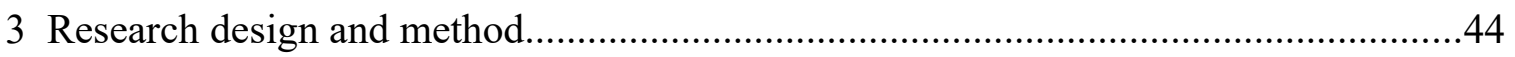

3.1 Step 1: Conceptual development....................................................................45

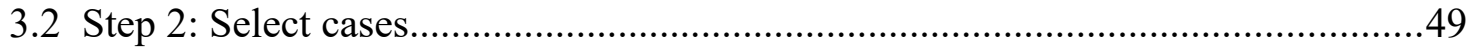

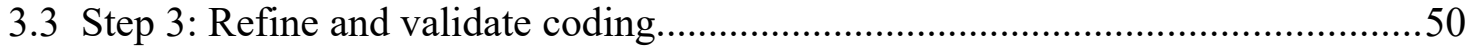

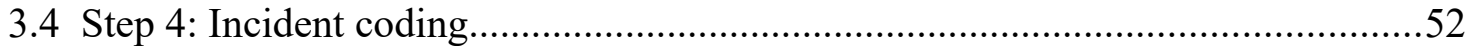

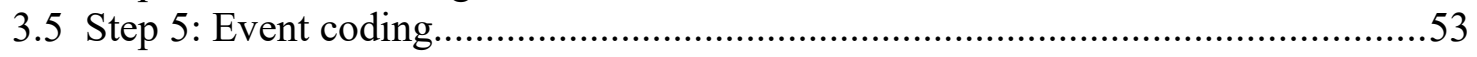

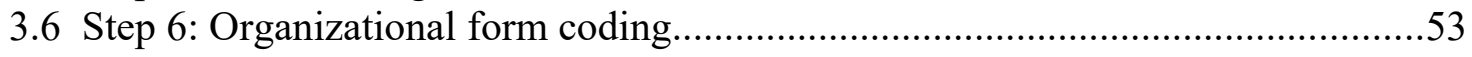

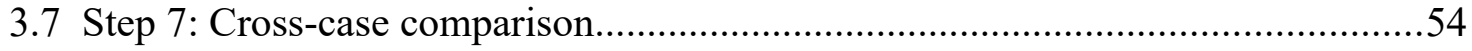


Emancipated entrepreneuring in the nascent commercial spaceflight industry:

Authoring ecosystems by Branson, Diamandis, and Musk. Copyright (C) 2018 Ewan Reid

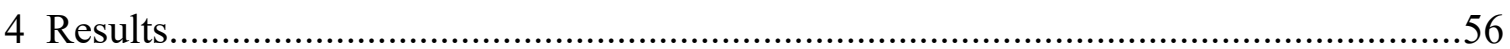

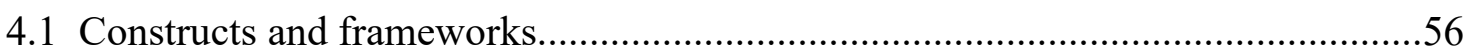

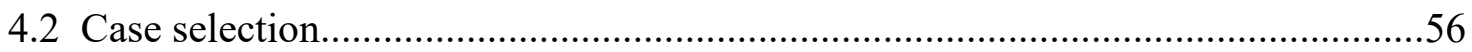

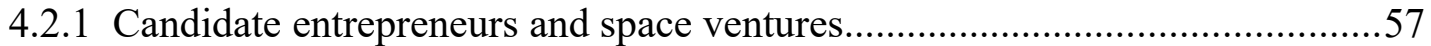

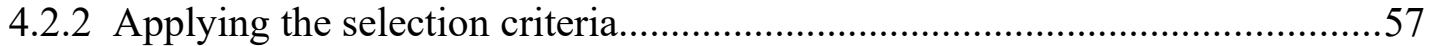

4.2.3 Case 1: Sir Richard Branson and Virgin Galactic.........................................59

4.2.4 Case 2: Peter Diamandis and XPRIZE........................................................59

4.2.5 Case 3: Elon Musk and SpaceX..................................................................6

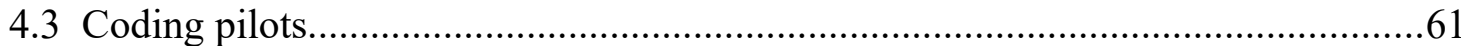

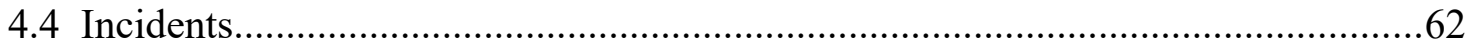

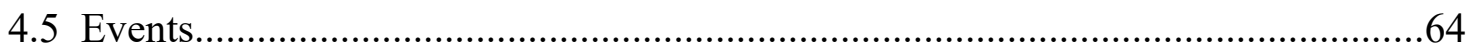

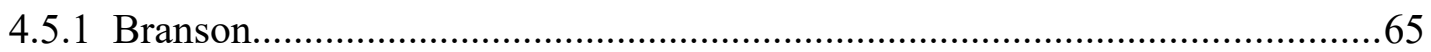

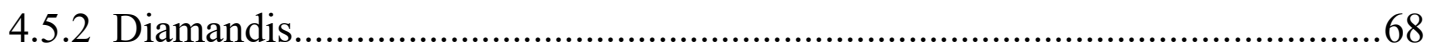

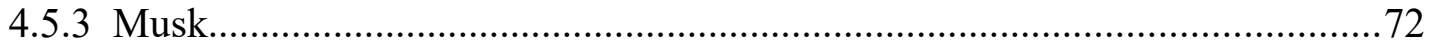

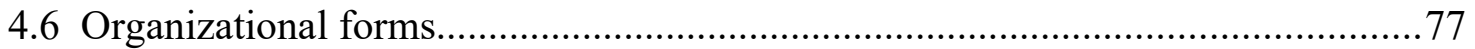

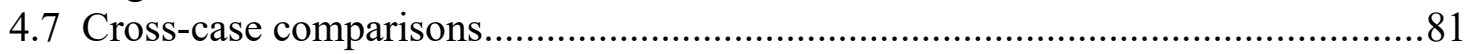

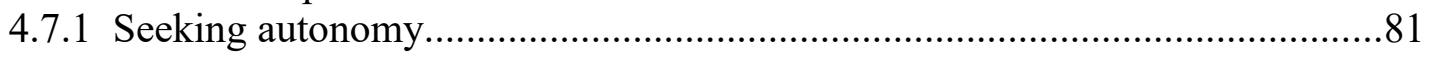

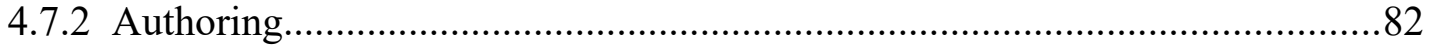

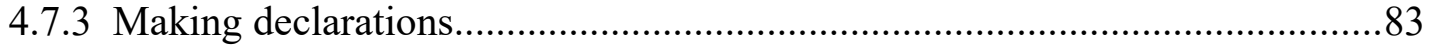

4.7.4 Organizational forms and ecosystem events.................................................83

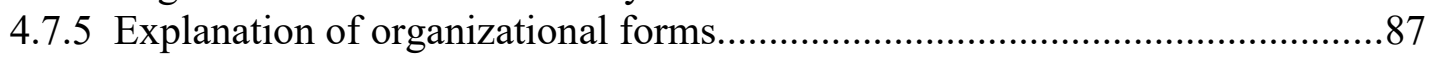

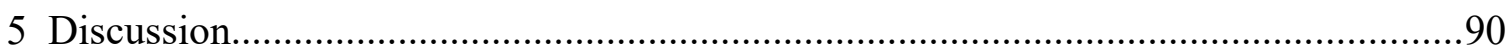

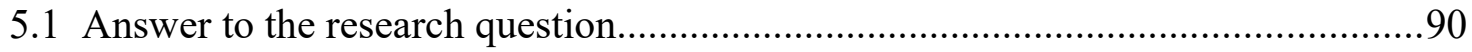

5.1.1 Conceptual links between ecosystems and emancipation.............................91

5.1.2 Prevalence of the business ecosystem organizational form............................93

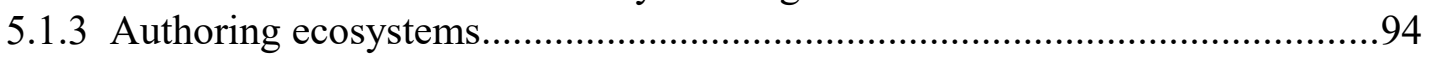

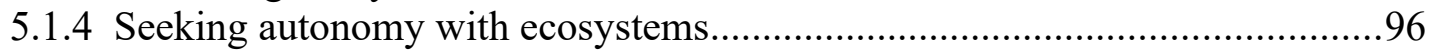

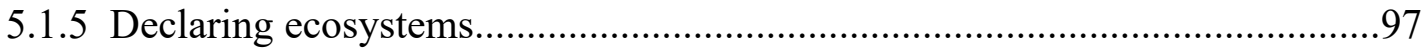

5.1.6 Selection of the business ecosystems organizational form..........................97

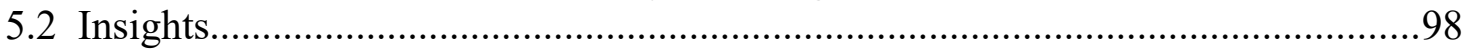

5.3 Empirical support for connecting ecosystems and emancipation........................... 102

5.4 Lessons learned from writing this thesis...................................................... 104

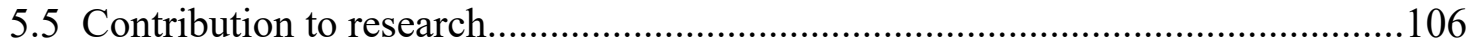

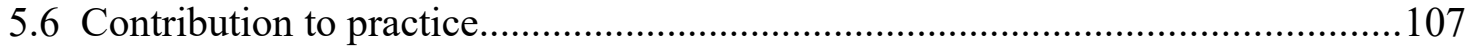

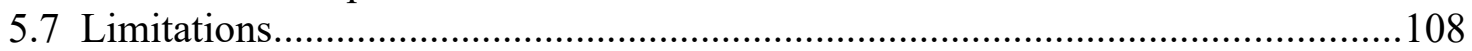

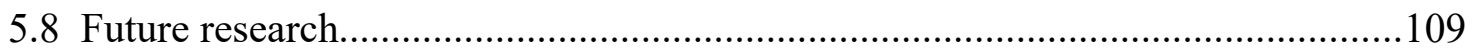

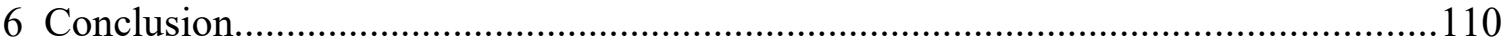

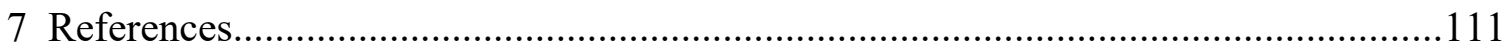

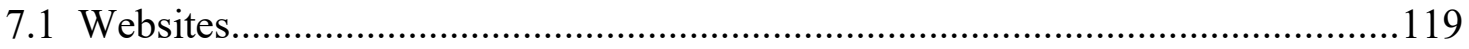


Emancipated entrepreneuring in the nascent commercial spaceflight industry: Authoring ecosystems by Branson, Diamandis, and Musk. Copyright (C) 2018 Ewan Reid

8 Appendix: Operational specification................................................................... 120

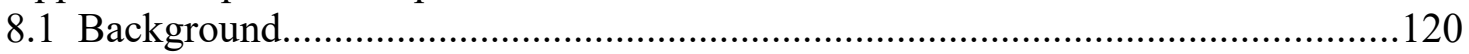

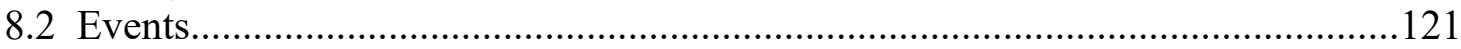

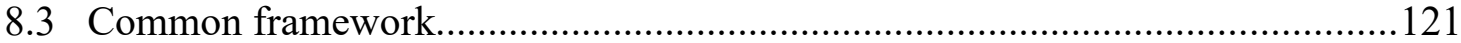

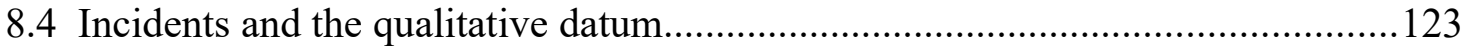

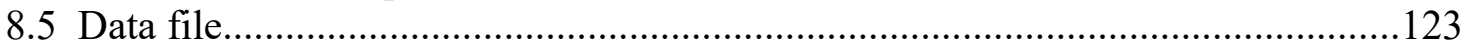

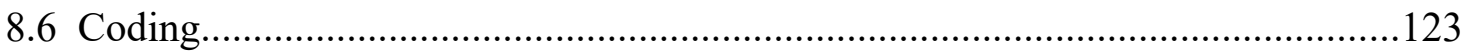

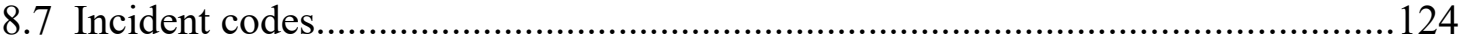


Emancipated entrepreneuring in the nascent commercial spaceflight industry:

Authoring ecosystems by Branson, Diamandis, and Musk. Copyright (C) 2018 Ewan Reid

\section{List of tables}

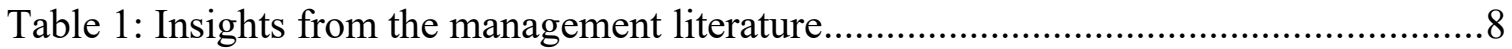

Table 2: Core elements of entrepreneuring (adapted from Rindova et al. 2009)..............10

Table 3: Seeking autonomy examples from Rindova et al. (2009)..................................12

Table 4: Authoring examples from Rindova et al. (2009)............................................13

Table 5: Making declarations examples from Rindova et al. (2009)..............................15

Table 6: Inventory of articles about entrepreneuring as emancipation............................16

Table 7: Comparison of empirical studies about entrepreneuring as emancipation..........18

Table 8: Journals publishing empirical studies about entrepreneuring as emancipation...22

Table 9: Markets, hierarchies, and business ecosystems (from Muegge, 2011a, p. 86;

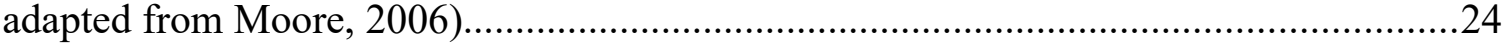

Table 10: Subset of related ideas that influenced Moore (2006)...................................25

Table 11: Connections between seeking autonomy and business ecosystems..................35

Table 12: Connections between authoring and business ecosystems............................38

Table 13: Connections between making declarations and business ecosystems..............40

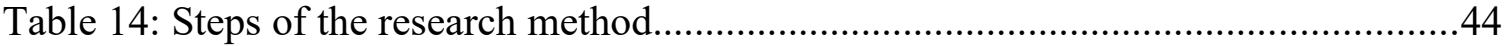

Table 15: Criteria for assigning organizational form codes, with examples...................55

Table 16: Candidate entrepreneurs and space ventures....................................................58

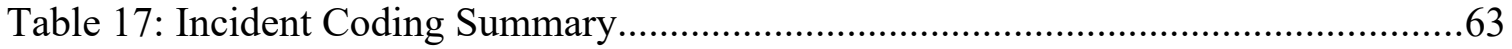

Table 18: Counts of events, by entrepreneur and event type......................................64

Table 19: Branson: seeking autonomy events...............................................................66

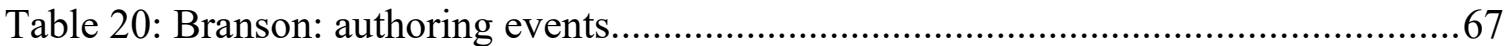

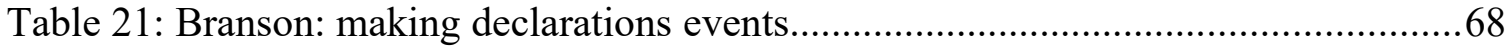

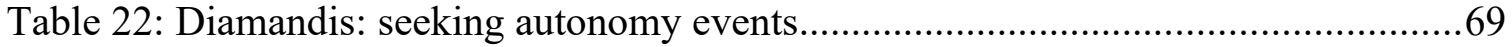

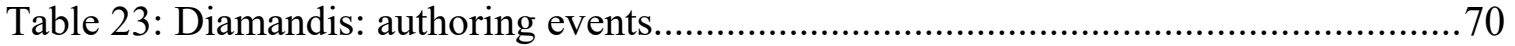

Table 24: Diamandis: making declarations events..................................................... 71

Table 25: Musk: seeking autonomy events (part 1 of 2)..............................................72

Table 26: Musk: seeking autonomy events (part 2 of 2).................................................73

Table 27: Musk: authoring events (part 1 of 2)................................................................. 74

Table 28: Musk: authoring events (part 2 of 2)............................................................... 75 
Emancipated entrepreneuring in the nascent commercial spaceflight industry: Authoring ecosystems by Branson, Diamandis, and Musk. Copyright (C) 2018 Ewan Reid

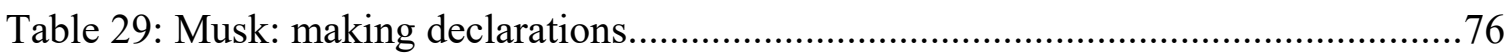

Table 30: Branson: Organizational forms of emancipation events...................................77

Table 31: Diamandis: Organizational forms of emancipation events..............................78

Table 32: Musk: Organizational forms of emancipation events......................................80

Table 33: Seeking autonomy events coded to the business ecosystem form....................84

Table 34: Authoring events coded to the business ecosystem form................................85

Table 35: Making declarations events coded to the business ecosystem form.................87 
Emancipated entrepreneuring in the nascent commercial spaceflight industry: Authoring ecosystems by Branson, Diamandis, and Musk. Copyright (C) 2018 Ewan Reid

\section{Introduction}

The emancipatory perspective on entrepreneuring was proposed by Violina Rindova, Daved Barry, and David Ketchen in the introduction to a 2009 Academy of Management Review special topics forum on "Entrepreneuring” (Rindova et al. 2009). This way of examining the activities undertaken by entrepreneurs - emphasizing verbs and actions rather than nouns and things - put a renewed focus on process and the particular ways in which entrepreneurs bring about change. Jennings et al. (2016) writes: "Every once in a while, a groundbreaking paper is published with paradigm-shifting potential. One of these is Rindova, Barry, and Ketchen's (2009) reconceptualization of entrepreneurial activity as a means of emancipation" (p. 81).

This thesis examines how business ecosystems (Moore, 1993, 1996, 2006, 2013; Iansiti \& Levien, 2004; Muegge, 2013; Muegge \& Mezen, 2017) feature in the emancipation actions of technology entrepreneurs - an open question thus far unaddressed in either the business ecosystems or the emancipatory entrepreneurship literatures. On one hand, there are compelling theoretical reasons to expect that business ecosystems could be emancipating. Baldwin \& von Hippel (2011) show that the open collaborative innovation processes that anchor many business ecosystems are increasingly viable as the costs of design and communication drop, Muegge (2013) argues that business ecosystems are one possible remedy to problems faced by earlystage technology entrepreneurs, and Muegge \& Mezen (2017) demonstrate an association between ecosystem participation with business model innovation. For technology 
entrepreneurs seeking autonomy, the first of the three core elements of the emancipation perspective, business ecosystems could be a possible means to "escape from or remove perceived constraints in their environments" (Rindova et al. 2009, p. 480). On the other hand, innovation within business ecosystems cannot be managed and controlled in the same ways as within markets (through contracts and enforcement through the legal system) or organizational hierarchies (through employment contracts and reporting relationships); asserting dominance and heavy-handed control of a business ecosystem is at best ineffective and potentially destructive (Iansiti \& Levien, 2004; Moore, 2013; Gawer \& Cusumano, 2014). Authoring, the second core element of the emancipation perspective, refers to "taking ownership" by "defining relationships, arrangements, and rules of engagement that preserve and potentially enhance the change potential of a given entrepreneurial project" (Rindova et al. 2009, p. 483). For technology entrepreneurs for whom "taking ownership" means "taking control", more traditional organizational forms with more overt control mechanisms may be more emancipating. Thus there are arguments both for and against the emancipatory potential of business ecosystems. This thesis is the first to examine empirically how business ecosystems feature in technology entrepreneurs' emancipatory actions.

The field setting for this research is commercial spaceflight. Martin (2014) writes: "NewSpace, alt.space, and entrepreneurial space are umbrella terms for a movement and philosophy often affiliated with, but not synonymous with, an emergent private spaceflight industry. Specifically, the terms are used to refer to a community of relatively new aerospace companies working to develop low-cost access to space or 
spaceflight technologies and advocates of low-cost spaceflight technology and policy." This industry segment was an appealing choice for four reasons. First, it is a nascent industry segment, with rapid technological change, and ambitious new entrants seeking to disrupt entrenched aerospace incumbents - characteristics likely to attract technology entrepreneurs dissatisfied with the status quo and seeking to bring about change. Second, it is poised for continued and accelerating growth, making any potential findings more relevant; Martin (2014) writes: "Increased competition and new capabilities will change the market place forever." Third, the new entrants in this segment have adopted a rich variety of organizational forms to challenge the status quo. Fourth, the author of this thesis is an experienced aerospace engineer and founder of a startup in an adjacent segment of the aerospace industry, and is familiar with the technologies and industry structure.

The three cases examined here are Sir Richard Branson and Virgin Galactic (https://virgingalactic.com), Peter Diamandis and XPRIZE (https://xprize.org), and Elon Musk and SpaceX (https://spacex.com). The main source material for each case was a published book: The Virgin Way: If it's not Fun, it's not Worth Doing (Branson, 2015), Bold: How to Go Big, Achieve Success, and Impact the World (Diamandis \& Kotler, 2015), and Elon Musk: Tesla, SpaceX, and the Quest for a Fantastic Future (Vance, 2015), respectively. 


\subsection{Objective}

This thesis seeks to answer the following research question:

How do business ecosystems feature in the emancipatory actions of entrepreneurs in the commercial spaceflight industry?

\subsection{Deliverables}

This thesis has four deliverables:

(1) operational specifications of the three emancipation constructs from the Rindova et al. (2009) emancipation perspective of entrepreneuring

(2) three case reports of entrepreneurs, their space ventures, and formal specification of their emancipation activities

(3) results of cross-case analysis of the three cases, and

(4) an answer to the research question

\subsection{Relevance}

The research question motivating this thesis is relevant to (1) entrepreneurs in the commercial spaceflight sector, and (2) management researchers interested in organizational forms and the motivations for entrepreneuring.

Entrepreneurs in the commercial spaceflight sector can benefit from a more complete understanding of the motivations of potential partners and rivals, and of selecting organizational forms matched to their own ambitions and temperament.

Management researchers can benefit by joining two literatures that were previously distinct, each addressing high-impact, managerially-relevant problems. Areas for follow-on research abound. Results about organizational forms and emancipation 
activities in the commercial spaceflight sector could be compared to other industry sectors, expanded to a larger set of entrepreneurs and ventures in the same sector, and revisited in the future to more fully understand the evolution and maturation of this stillnascent segment.

\subsection{Contribution}

This thesis makes two contributions to management research and one contribution to management practice.

The first contribution to management research is the operational specification for an event study using the emancipation perspective on entrepreneuring (Rindova et al. 2009), developed in chapter 3 (Research design and method) and chapter 4 (Results), and presented in its complete form in chapter 8 (Appendix: Operational specification ). Other researchers can employ this approach to study the emancipatory actions of technology entrepreneurs in other domains.

The second contribution to management research is the joining of two domains (in chapter 5) - the emancipatory perspective of entrepreneuring and business ecosystems -

which were previously distinct. Business ecosystems feature in the emancipatory actions of entrepreneurs in the commercial spaceflight industry in three ways: (1) as a means of seeking autonomy by breaking free of or breaking up perceived constraints, (2) in the authoring activities to realize change (including the work to create a new business ecosystem or to join, maintain, grow, or change an established ecosystem), and (3) in the making declarations activities to mobilize support, manage interpretations by 
stakeholders, and generate change effects in others. This joining of literatures opens up new research opportunities in both domains.

The contribution to management practice is the formal specification of emancipatory actions by Branson, Diamandis, and Musk, presented in chapter 4 (Results) especially sections 4.4 (Incidents), 4.5 (Events), 4.6 (Organizational forms), and 4.7 (Cross-case comparisons), developed by following a rigorous, reproducible, welldocumented procedure presented in chapter 3 (Research design and method). Other technology entrepreneurs can benefit from these accounts of seeking autonomy, authoring, and making declarations by the founders of Virgin Galactic, XPRIZE, and SpaceX.

\subsection{Overview of research design and method}

The research design of this thesis is an event study combining the case methods of Yin (2014) and Eisenhardt (1989; q.v., Eisenhardt \& Graebner, 2007; Eisenhardt et al. 2016) with process theory methods from Van de Ven (2007; q.V., Van de Ven et al. 1999; Poole et al. 2000) to operationalize the three core constructs of the Rindova et al. (2009) emancipation perspective of entrepreneuring. The source material for each case was a published book, authored by the focal entrepreneur or written about the focal entrepreneur and their commercial spaceflight venture. The source material was coded in NVivo, a software package for qualitative data analysis from QSR International (https://qsrinternational.com). There were three sequential rounds of coding for each case: (1) incident coding of the source material to identify and tag relevant passages of text, (2) event coding of the incidents to identify and formally specify a set of 
emancipation events, and (3) organizational form coding to identify the organizational forms that feature in each emancipation event. The answer to the research question emerged from cross-case analysis of the three cases: (1) Sir Richard Branson, founder of Virgin Galactic, (2) Peter Diamandis, founder and executive chairman of XPRIZE, and (3) Elon Musk, founder and CEO of SpaceX.

\subsection{Organization of the document}

This thesis is organized as seven chapters, each structured into sections and subsections. Chapter 2, "Literature review," summarizes and interprets the relevant findings from the prior literature on entrepreneuring as emancipation and business ecosystems, and explores the conceptual and theoretical connections between the two streams of research. Chapter 3, "Research design and method," presents the research design and detailed method to answer the research questions, including the development of an operational specification for an event study of the emancipation perspective of entrepreneuring. Chapter 4, "Results," presents the outcomes of each step of the research method. Chapters 5, "Discussion," provides the answer to the research question, discusses the results and positions the thesis contribution with respect to the prior literature, reports the limitations of the current research, and explores opportunities for future research. Chapter 6, "Conclusion," concludes the thesis. Chapter 7, "References," provides references to all sources cited in the document. An appendix provides the operational specification for the event study. 
Emancipated entrepreneuring in the nascent commercial spaceflight industry:

Authoring ecosystems by Branson, Diamandis, and Musk. Copyright (C) 2018 Ewan Reid

\section{Literature review}

Table 1 organizes the relevant literature as two streams and summarizes the

highlights most relevant to the thesis research question. The following two sections

briefly review each stream, the third section brings the streams together and identifies and

theorizes about common elements between them, and the fourth and final section presents

a summary and synthesis of the insights from across the literature that are most relevant

to this research.

Table 1: Insights from the management literature

\begin{tabular}{|c|c|c|}
\hline Stream & Key highlights of the stream & Citations to key sources \\
\hline $\begin{array}{l}\text { Entrepreneuring } \\
\text { as emancipation }\end{array}$ & $\begin{array}{l}\text { - Emancipation refers to "the act of setting free from the } \\
\text { power of another" (Webster's Revised Unabridged } \\
\text { Dictionary, 1996). The focal point of inquiry is "pursuit } \\
\text { of freedom and autonomy relative to an existing status } \\
\text { quo" (Rindova et al. 2009, p. 478). } \\
\text { - Three core elements of an emancipatory perspective } \\
\text { on entrepreneuring: (I) seeking autonomy, } \\
\text { (ii) authoring, and (iii) making declarations } \\
\text { - Described by Jennings et al. (2016, p. 81) as } \\
\text { "groundbreaking", with "paradigm-shifting potential" }\end{array}$ & $\begin{array}{l}\text { Rindova et al. (2009) } \\
\text { Jennings et al. (2016) } \\
\text { Goss et al. (2011) } \\
\text { Mair et al. (2012) } \\
\text { Pless \& Appel (2012) } \\
\text { Scott et al. (2012) } \\
\text { Marti et al. (2013) } \\
\text { Verduijn \& Essers (2013) }\end{array}$ \\
\hline $\begin{array}{l}\text { Business } \\
\text { ecosystems }\end{array}$ & $\begin{array}{l}\text { - A business ecosystem is "a field of economic actors } \\
\text { whose individual business activities, anchored around } \\
\text { a platform, share in some large measure the outcome } \\
\text { of the whole ecosystem" (Muegge, 2013) } \\
\text { - Moore (2006) argues that business ecosystems are a } \\
\text { distinct organizational form - a mode of organizing } \\
\text { economic production that differs from markets and } \\
\text { organizational hierarchies } \\
\text { - Business ecosystems can provide a partial remedy to } \\
\text { the problems faced by technology entrepreneurs } \\
\text { - Open-collaborative innovation becomes a viable mode } \\
\text { of production as design and communication costs fall }\end{array}$ & $\begin{array}{l}\text { Moore }(1993,2006,2013) \\
\text { lansiti \& Levien }(2004) \\
\text { Baldwin \& von Hippel (2011) } \\
\text { Muegge (2013) } \\
\text { Gawer (2014) } \\
\text { Gawer \& Cusumano (2014) } \\
\text { Muegge \& Mezen (2017) } \\
\text { Adner (2017) }\end{array}$ \\
\hline
\end{tabular}

\subsection{Entrepreneuring as emancipation}

Rindova et al. (2009) proposed an emancipatory perspective on entrepreneuring

with three core elements: (i) seeking autonomy, (ii) authoring, (iii) making declarations.

"We theorize that the three core elements are central to an emancipatory process" (p. 
479); the core elements "are not intended to provide a fully articulated theoretical perspective but, rather, to stimulate a conversation in the field about both the research questions that emerge when entrepreneuring is viewed as emancipation and the novel research directions that these questions open up" (p. 479).

"We define 'entrepreneuring' as efforts to bring about new economic, social, institutional, and cultural environments throughout the actions of an individual or group of individuals" (p. 477). It is about creation of something new - not merely change.

Emancipation refers to "the act of setting free from the power of another" (Webster's Revised Unabridged Dictionary, 1996). The focal point of inquiry is "pursuit of freedom and autonomy relative to an existing status quo" (Rindova et al., 2009, p. 478).

"The emancipatory perspective does not negate wealth creation but instead emphasizes change creation" (p. 479). "We believe that entrepreneurship research perhaps has become a bit too narrowly focused on wealth creation via new ventures" (p. 478). "We are motivated by the belief that research that considers both more closely and more broadly the entrepreneurial dreams and efforts to create change in the world may bring us to a fuller, more comprehensive understanding of the processes of discovery, change, value creation, and ultimately wealth creation" (p. 478). "The implied opposition between emancipatory projects to create change and a 'hard-nosed business strategy' is a false one" (p. 483).

Table 2 is a summary of the three core elements of Rindova et al. (2009). 
Table 2: Core elements of entrepreneuring (adapted from Rindova et al. 2009)

\begin{tabular}{|c|c|c|c|}
\hline & Seeking autonomy & Authoring & Making declarations \\
\hline $\begin{array}{l}\text { Entrepreneuring viewed } \\
\text { as an emancipatory } \\
\text { process } \\
\text { (Table } 1, \text { p. 480) }\end{array}$ & $\begin{array}{l}\text { - Actors seek to escape from or remove } \\
\text { perceived constraints in their environments } \\
\text { - Constraints are perceived in a variety of } \\
\text { environments: economic, social, } \\
\text { technological, cultural, and institutional }\end{array}$ & $\begin{array}{l}\text { - The rules of engagement with key resource } \\
\text { providers should reflect change-creating intent } \\
\text { - Organizational arrangements can be designed } \\
\text { to preserve emancipatory potential }\end{array}$ & $\begin{array}{l}\text { - Making declarations about intended change } \\
\text { is essential to mobilize support and generate } \\
\text { change effects }\end{array}$ \\
\hline $\begin{array}{l}\text { Contrast with the } \\
\text { dominant themes in } \\
\text { traditional } \\
\text { entrepreneurship } \\
\text { research } \\
\text { (Table 1, p. 480) }\end{array}$ & $\begin{array}{l}\text { - Opportunity recognition } \\
\text { - Opportunity creation through technological } \\
\text { innovation }\end{array}$ & $\begin{array}{l}\text { - Familiar and legitimate organizational forms } \\
\text { enhance survival } \\
\text { - Affiliations with high-status actors also increase } \\
\text { legitimacy and survival chances }\end{array}$ & $\begin{array}{l}\text { - Tangible investments in technologies, } \\
\text { products, and human capital drive } \\
\text { perceptions of value and meaning of } \\
\text { entrepreneurial efforts } \\
\text { - Symbolic and cultural means are used to } \\
\text { increase perceived fit of investments with } \\
\text { existing values and cultural accounts }\end{array}$ \\
\hline $\begin{array}{l}\text { Etymology } \\
\text { (pp. 480, 483, 485) }\end{array}$ & Ex: breaking free and breaking up & $\begin{array}{l}\text { Mancipare: taking ownership of oneself and one's } \\
\text { acts }\end{array}$ & $\begin{array}{l}\text { Usage: Declaration of Independence, } \\
\text { Emancipation Proclamation }\end{array}$ \\
\hline $\begin{array}{l}\text { Role in entrepreneuring } \\
\text { (p. 479) }\end{array}$ & Entrepreneurial impetus & Actions to organize resource exchanges & Actions to manage stakeholder interpretations \\
\hline $\begin{array}{l}\text { What an entrepreneur } \\
\text { does (p. 479) }\end{array}$ & $\begin{array}{l}\text { Overcome or remove perceived constraints of } \\
\text { an intellectual, psychological, economic, } \\
\text { social, institutional, or cultural nature }\end{array}$ & $\begin{array}{l}\text { Position the entrepreneurial project in a system of } \\
\text { exchange relationships with resource holders }\end{array}$ & $\begin{array}{l}\text { Position the entrepreneurial project in the } \\
\text { webs of meaning within which stakeholders } \\
\text { interpret the value of products and activities }\end{array}$ \\
\hline Examples & $\begin{array}{l}\text { 1. Google's founding story "exemplifies the } \\
\text { elements of breaking free (setting out to do } \\
\text { things their own way) and breaking up } \\
\text { (downloading the internet to improve upon } \\
\text { early search engines)" (p. 481) } \\
\text { 2. Google's disdain for the status quo inviting } \\
\text { legal battles (p. 482): scanning books } \\
\text { (disregarding copyright), retaining personal } \\
\text { search data indefinitely, storing email on its } \\
\text { own servers (a target for law enforcement } \\
\text { abuse), inserting ads in emails, making cheap } \\
\text { personal computers }\end{array}$ & $\begin{array}{l}\text { 1. Google's unconventional group leadership } \\
\text { structure with three leaders (pp. 483-484) } \\
\text { 2. Google's non-conformance with standard Wall } \\
\text { Street practices, by providing no guidance on } \\
\text { earnings, and an IPO by share auction rather than } \\
\text { underwriting (p. 484) } \\
\text { 3. Grameen Bank's relationships with borrowers } \\
\text { in the poorest parts of the population: meetings in } \\
\text { the borrowers' homes and villages, loan } \\
\text { repayments in small weekly installments, no legal } \\
\text { instrument between lender and borrower, no } \\
\text { stipulation of using courts to recover a loan, } \\
\text { efforts to help a borrower in difficulty to regain } \\
\text { strength, and maximum limits on interest (p. 484) }\end{array}$ & $\begin{array}{l}\text { 1. Larry Page dreamed of "making millions of } \\
\text { books searchable by anybody in the world } \\
\text { with an Internet connection" ( } p .486 \text { ) } \\
\text { 2. Amazon declared itself to be "Earth's } \\
\text { biggest bookstore" ( } p .485) \\
\text { 3. Thomas Edison declared that he had } \\
\text { discovered how to make electricity a cheap } \\
\text { and practical substitute to gas (p. 486) }\end{array}$ \\
\hline
\end{tabular}


Each of the three core elements is further examined in the next three subsections.

\subsubsection{Seeking autonomy}

Seeking autonomy is the "entrepreneurial impetus" (Rindova et al. 2009, p. 479) the perceived need of the entrepreneur to break free of or break up a perceived constraint in the environment. For Schumpeter, creative destruction was a means of entrepreneurship, but in the emancipation perspective it is also a goal.

The seminal article by Rindova et al. (2009) described eight real-world examples of emancipation (previously summarized in the bottom row of Table 2) - five by the Google founders, and one each by Jeff Bezos of Amazon.com, Thomas Edison, and the Grameen Bank. These Rindova et al. (2009) examples were presented in a narrative form - paragraphs of descriptive text, with facts and quotations compiled from various cited sources. To explore whether or not an occurrence of seeking autonomy - what we will later in chapter 3 define precisely as a seeking autonomy event - can be expressed as an operational construct and what the components of that construct might be, we rework Rindova's examples into a tabular format in Table 3 (on the following page).

The format employed here for Table 3, and for the tables that follow in the next two subsections, is adapted from the common framework developed later in this document as an outcome of step 3 of the research method (explained in chapter 3 ). These tables were an outcome of coding pilot \#2 (method described in section 3.3, and results presented in section 4.3), but are presented here with the literature review of the emancipation perspective for convenience to the reader. 
Table 3: Seeking autonomy examples from Rindova et al. (2009)

\begin{tabular}{|c|c|c|c|}
\hline Example & Perceived constraint & $\begin{array}{l}\text { Breaking free of the } \\
\text { perceived constraint }\end{array}$ & $\begin{array}{l}\text { Breaking up the } \\
\text { perceived constraint }\end{array}$ \\
\hline \multirow[t]{2}{*}{$\begin{array}{l}\text { 1. Google's founding } \\
\text { story (p. } 481 \text { ) }\end{array}$} & \multirow{2}{*}{$\begin{array}{l}\text { Early internet search } \\
\text { engines were primitive. } \\
\text { Search algorithms were } \\
\text { limited (a technological } \\
\text { constraint), and the } \\
\text { information made } \\
\text { available was limited (a } \\
\text { cultural constraint) }\end{array}$} & $\begin{array}{l}\text { "Setting out to do things } \\
\text { their own way" }\end{array}$ & $\begin{array}{l}\text { "Downloading the } \\
\text { internet to improve upon } \\
\text { early search engines" }\end{array}$ \\
\hline & & $\begin{array}{l}\text { Development of Google } \\
\text { PageRank technology }\end{array}$ & $\begin{array}{l}\text { Development of Google } \\
\text { PageRank technology }\end{array}$ \\
\hline \multirow{7}{*}{$\begin{array}{l}\text { 2. Google's "disdain for } \\
\text { the status quo ... and } \\
\text { voracious appetite for } \\
\text { aggressively pursuing } \\
\text { initiatives to bring about } \\
\text { radical change" (p. 482) }\end{array}$} & & $\begin{array}{l}\text { "aggressively [pursue] } \\
\text { initiatives to bring about } \\
\text { radical change" }\end{array}$ & $\begin{array}{l}\text { Inviting "legal battles with } \\
\text { landmark significance" }\end{array}$ \\
\hline & & \multicolumn{2}{|c|}{$\begin{array}{l}\text { "Compiling a genetic and biological database using } \\
\text { the vast power of its search engines" }\end{array}$} \\
\hline & Copyright law & \multicolumn{2}{|c|}{$\begin{array}{l}\text { "Scanning millions of books without traditional } \\
\text { regard for copyright laws" }\end{array}$} \\
\hline & $\begin{array}{l}\text { Conventions and user } \\
\text { expectations of privacy; } \\
\text { limited knowledge about } \\
\text { users performing search }\end{array}$ & \multicolumn{2}{|c|}{$\begin{array}{l}\text { "Tracing online search to individual Internet users } \\
\text { and storing them indefinitely" }\end{array}$} \\
\hline & $\begin{array}{l}\text { Norms about what } \\
\text { providers of search } \\
\text { technology do }\end{array}$ & \multicolumn{2}{|c|}{$\begin{array}{l}\text { "Demanding cell phone numbers in exchange for } \\
\text { free e-mail accounts (known as Gmail) as it begins } \\
\text { to build the first global cell phone directory" }\end{array}$} \\
\hline & $\begin{array}{l}\text { Limited email storage; } \\
\text { users need to regularly } \\
\text { delete old emails to free } \\
\text { up space for new emails }\end{array}$ & \multicolumn{2}{|c|}{$\begin{array}{l}\text { "Saving Gmails forever on its own servers, making } \\
\text { them a tempting target for law enforcement abuse" }\end{array}$} \\
\hline & & \multicolumn{2}{|c|}{$\begin{array}{l}\text { "Making hundreds of thousands of cheap personal } \\
\text { computers to serve as cogs in powerful global } \\
\text { networks" }\end{array}$} \\
\hline
\end{tabular}

\subsubsection{Authoring}

Authoring refers to taking ownership by defining relationships, arrangements, and rules of engagement, and changing the positions of power. "Authoring does not refer to an outright rejection of all established norms and forms of authority but, rather, designing arrangements that support the change-creating intent of the entrepreneuring individual" (p. 484). It is not a privilege of the rich and powerful, but rather of anyone who can somehow effect "trading of places" (p. 484). It contrasts with the themes of opportunity 
recognition and opportunity creation through technological innovation that dominate entrepreneurship research.

Table 4 summarizes the Rindova et al. (2009) authoring examples in tabular form.

Table 4: Authoring examples from Rindova et al. (2009)

$\begin{array}{lll}\text { Example } & \begin{array}{l}\text { Old status quo to be } \\ \text { changed }\end{array} & \begin{array}{l}\text { New arrangement supporting change-creating } \\ \text { intent }\end{array}\end{array}$

1. Google's unconventional group leadership structure with three leaders (pp. 483484)

2. Google's IPO (pp. 484)
Conventional corporate governance and leadership structures; the Board of Directors appoints a CEO to the lead a company

Standard Wall Street practices for an IPO: one share = one vote; earnings guidance to analysts;

underwriter allocates shares
"Trio, troika, or triumvirate" of Larry Page, Sergey Brin, and CEO Eric Schmidt, who "do everything in groups."

The new arrangement meets institutional expectations without giving up authority. It preserve autonomy and mobilizes the resources needed to support autonomy

"We make our own rules"

Management trio owns one-third of shares but controls $80 \%$ of shareholder votes.

Google Owner's Manual: "Google is not a conventional company. We do not intend to become one... You are placing an unusual long-term bet on the team."

No earnings guidance to analysts

Allocate shares by auction

The new arrangement protects the founders' intent for continued change creation, despite demands from resource holders

3. Grameen Bank's relationships with borrowers (p. 484)
Conventional relationships between banks and borrowers
New relationships with underprivileged and disempowered actors in the poorest part of the world

Meetings occur at the bank Staff meet borrowers in their homes in rural villages

Legal instrument between No legal instrument between lender and borrower lender and borrower

Stipulation that a client will No stipulation that a client will be taken to a court of be taken to a court of law to law to recover a loan recover a loan

Act to recover the money if the borrower gets into difficulty

Act to help a borrower regain strength if the borrower gets into difficulty

Interest charged on a loan can be a multiple of the Total interest on a loan cannot exceed the amount of the loan; no interest is charged after the interest principal depending on the amount equals to principal length of the loan period 


\subsubsection{Making declarations}

Making declarations refers to "unambiguous discursive and rhetorical acts regarding the actor's intentions to create change" (Rindova et al. 2009, p. 485). "Declarations are intended for specific audiences and are bound by customs of rhetoric, speaking, and listening" (p. 486). Unlike legitimation activities that disguise differences, entrepreneuring may involve exposing contractions and differences to generate stakeholder support for an intended change in the status quo. Contestations from others may be an inevitable consequence of declarations: "The process of declaration and contestation is not simply one of deploying economic resources to alter the attractiveness of an opportunity, but is also one of meaning and rhetoric and ultimately of altering societal beliefs about the very nature of things" (p. 486). Possible properties are the magnitude of a declaration, the strength of contestations, and the resulting intensity of stakeholder support.

Table 5 summarizes the Rindova et al. (2009) examples of making declarations in a tabular form. 
Table 5: Making declarations examples from Rindova et al. (2009)

\begin{tabular}{|c|c|c|c|c|}
\hline Example & $\begin{array}{l}\text { Statement of } \\
\text { intent to } \\
\text { create change }\end{array}$ & $\begin{array}{l}\text { Forms of the } \\
\text { discursive or } \\
\text { rhetorical acts }\end{array}$ & $\begin{array}{l}\text { Contestations } \\
\text { from others }\end{array}$ & $\begin{array}{l}\text { Overcoming } \\
\text { contestations }\end{array}$ \\
\hline $\begin{array}{l}\text { 1. Larry Page dreamed of } \\
\text { "making millions of books } \\
\text { searchable by anybody in } \\
\text { the worlds with an internet } \\
\text { connection (p. } 486 \text { ) }\end{array}$ & $\begin{array}{l}\text { Anybody in the } \\
\text { world with an } \\
\text { internet } \\
\text { connection will } \\
\text { be able to } \\
\text { search millions } \\
\text { of books }\end{array}$ & "Dreams", "efforts" & $\begin{array}{l}\text { Lawsuits } \\
\text { claiming } \\
\text { copyright } \\
\text { infringement. }\end{array}$ & $\begin{array}{l}\text { "“Google fired back [in } \\
\text { court], saying } \\
\text { copyright laws were } \\
\text { meant to serve the } \\
\text { public interest and } \\
\text { didn't apply in the } \\
\text { digital realm of } \\
\text { search" (p. 496) }\end{array}$ \\
\hline $\begin{array}{l}\text { 2. Amazon declared itself } \\
\text { to be the "Earth's biggest } \\
\text { bookstore" (p. 485). }\end{array}$ & $\begin{array}{l}\text { We are "Earth's } \\
\text { biggest } \\
\text { bookstore" }\end{array}$ & $\begin{array}{l}\text { Advertising (implied } \\
\text { but not explicitly } \\
\text { stated): } \\
\text { "Amazon.com } \\
\text { entered the book } \\
\text { market with a } \\
\text { declaration..." (p. } \\
485 \text { ) }\end{array}$ & $\begin{array}{l}\text { Competitor } \\
\text { Barnes \& } \\
\text { Noble sued } \\
\text { Amazon for } \\
\text { making false } \\
\text { claims. }\end{array}$ & $\begin{array}{l}\text { Amazon enhanced its } \\
\text { declarations by } \\
\text { launching new ads } \\
\text { with vivid symbols } \\
\text { conveying superiority }\end{array}$ \\
\hline $\begin{array}{l}\text { 3. Thomas Edison declared } \\
\text { that he had discovered how } \\
\text { to make electricity a cheap } \\
\text { and practical substitute to } \\
\text { gas (p. 486). }\end{array}$ & $\begin{array}{l}\text { Electricity is a } \\
\text { cheap and } \\
\text { practical } \\
\text { substitute to } \\
\text { gas }\end{array}$ & $\begin{array}{l}\text { Not stated: "Edison } \\
\text { declared..." (p. 486) }\end{array}$ & $\begin{array}{l}\text { Ridicule; } \\
\text { insulting and } \\
\text { derisive public } \\
\text { statements }\end{array}$ & None stated. \\
\hline
\end{tabular}

\subsubsection{Inventory of published articles}

Table 6 is an inventory of the fifty peer-reviewed journal articles about entrepreneuring as emancipation published as of February 2017. It includes 41 articles returned in a search of the Business Source Complete database for articles citing Rindova et al. (2009), four articles published in the Academy of Management Review 2009 Special Topics Forum on Entrepreneuring - the issue introduced by Rindova et al. (2009) - four articles published in the Technology Innovation Management Review (a journal not indexed by Business Source Complete), and one article discovered through Google Scholar. 
Table 6: Inventory of articles about entrepreneuring as emancipation

\begin{tabular}{|c|c|c|}
\hline Year & Count & Citations to articles \\
\hline 2009 & 4 & Blatt (2009). Calás et al. (2009). Cardon et al. (2009). Webb et al. (2009). \\
\hline 2010 & 5 & $\begin{array}{l}\text { Branzei \& Abdelnour (2010). King \& Pearce (2010). Koçak et al. (2010). } \\
\text { Levie \& Lichtenstein (2010). Short et al. (2010). }\end{array}$ \\
\hline 2011 & 4 & Goss et al. (2011). Kisfalvi \& Maguire (2011). Mitchell (2011). Webb et al. (2011). \\
\hline 2012 & 7 & $\begin{array}{l}\text { Hughes et al. (2012). Hudson (2012). Mair et al. (2012). Pless \& Appel (2012). } \\
\text { Pattie et al. (2012). Scott et al. (2012). von Krogh et al. (2012) }\end{array}$ \\
\hline 2013 & 6 & $\begin{array}{l}\text { Bruton et al. (2013). Bullough (2013). Doern \& Gross (2013). Marti et al. (2013). } \\
\text { Tobias et al. (2013). Verduijn \& Essers (2013). }\end{array}$ \\
\hline 2014 & 10 & $\begin{array}{l}\text { Bissola et al. (2014). Burg \& Romme (2014). Busenitz et al. (2014). } \\
\text { Gupta et al. (2014). Miron \& Hudson (2014). Hermes \& Mainela (2014). } \\
\text { Huault et al. (2014). Marlow \& Swail (2014). Mainela et al. (2014). Payette (2014). }\end{array}$ \\
\hline 2015 & 7 & $\begin{array}{l}\text { Adams \& Makramalla (2015). Ahl \& Nelson (2015). Baldacchino et al. (2015). } \\
\text { Baron et al. (2015). Marti \& Fernandez (2015). Tedmanson et al (2015). } \\
\text { van Werven et al. (2015) }\end{array}$ \\
\hline 2016 & 7 & $\begin{array}{l}\text { Baron et al. (2016). Courpasson (2016). Dey \& Steyaert (2016). } \\
\text { Haugh \& Talwar (2016). Jennings et al. (2016). McMullen \& Warnick (2016). } \\
\text { Ritala et al. (2016). }\end{array}$ \\
\hline 8 years & 50 & reviewed journal articles published annually. \\
\hline
\end{tabular}

According to Jennings et al. (2016), the extant published research offers "vivid and touching accounts of entrepreneurship's emancipatory power" focusing mainly on "subsets of individuals arguably most in need of liberation from the social order in which they are embedded" (p. 82) - primarily, females in developing countries or marginalized women within more developed nations. Themes include entrepreneurial passion (Cardon et al. 2009), entrepreneurship and innovation in the informal economy operating outside of government regulation (Webb et al. 2009), and coping with novelty by authoring relationships with communities, teams, and organizations (Blatt, 2009). According to Blatt, caring about one another's needs (i.e., by adopting communal relational schemas) and making expectations explicit and apparent (i.e., through contracting practices) are 
mechanisms to cope with novelty. Calás et al. (2009) adopts a critical perspective, reminding that entrepreneuring also has potentially destructive and exploitative aspects with respect to both human and natural resources.

The Rindova et al. (2009) examples from Table 2 through Table 5 were of technology ventures, but few of the articles citing Rindova from Table 6 have revisited the technology entrepreneurship domain. Three notable exceptions are Hudson (2012), Miron \& Hudson (2014), and Payette (2014), all published in the Technology Innovation Management Review. Hudson (2012) and Miron \& Hudson (2014) cite Rindova et al. (2009) to support an argument that entrepreneurs are motivated by desires other than profit. Rindova et al. (2009) had argued that seeking autonomy can be an impetus for entrepreneurship (p. 479): "Entrepreneuring therefore is undertaken not only to pursue opportunities but to overcome or remove perceived constraints in actors' environments." Payette (2014) examines the tensions between legitimacy and novelty faced by earlystage technology entrepreneurs: "new ventures by definition must avoid conformity in order to survive, because existing norms represent constraints that new ventures must overcome" (p. 24).

\subsubsection{Empirical studies of entrepreneuring as emancipation}

Table 7 is a comparison of seven empirical studies about entrepreneuring as emancipation published in peer-reviewed management journals. Of particular interest for this thesis is the ways in which previous researchers have operationalized the core elements of the emancipatory perspective. 


\section{Table 7: Comparison of empirical studies about entrepreneuring as emancipation}

\begin{tabular}{|c|c|c|c|c|}
\hline Citation & Where published & Research design & Field setting & Operationalization of emancipation constructs \\
\hline \multirow[t]{2}{*}{$\begin{array}{l}\text { Goss et al. } \\
(2011)\end{array}$} & \multirow[t]{2}{*}{ Organization Studies } & \multirow[t]{2}{*}{ Single case study } & \multirow{2}{*}{$\begin{array}{l}\text { Social venture supporting } \\
\text { ethnic minorities in cases of } \\
\text { domestic violence, forced } \\
\text { marriage and 'honour' based } \\
\text { violence }\end{array}$} & $\begin{array}{l}\text { Emancipatory potential is "an outcome of organized processes } \\
\text { (interaction rituals) involving constraint and agency" (p. 212). }\end{array}$ \\
\hline & & & & $\begin{array}{l}\text { Entrenched power relationships can be a constraint to be overcome. } \\
\text { Entrepreneurial agency (breaking free of the power of another) } \\
\text { unfolds over time through social situations. }\end{array}$ \\
\hline $\begin{array}{l}\text { Mair et al. } \\
(2012)\end{array}$ & $\begin{array}{l}\text { Journal of Business } \\
\text { Ethics }\end{array}$ & $\begin{array}{l}\text { Content and cluster } \\
\text { analysis; sample of } 200 \text { social } \\
\text { entrepreneurial organizations }\end{array}$ & $\begin{array}{l}\text { Social ventures from the } \\
\text { Ahsoka Foundation and the } \\
\text { Schawab Foundation }\end{array}$ & $\begin{array}{l}\text { Emancipation is "the transformative ambition that characterize[s] } \\
\text { social entrepreneurship" (p. 353). }\end{array}$ \\
\hline $\begin{array}{l}\text { Pless \& Appel } \\
(2012)\end{array}$ & $\begin{array}{l}\text { Journal of Business } \\
\text { Ethics }\end{array}$ & Single case study & $\begin{array}{l}\text { India: Gram Vikas } \\
\text { (an NGO) }\end{array}$ & $\begin{array}{l}\text { Entrepreneuring can "contribute to implementing social change ... at } \\
\text { the individual level, community level and ultimately societal level" (p. } \\
\text { 404). Thus social entrepreneurship can be emancipating, "breaking } \\
\text { the vicious circle of poverty" (p. 389), and "creating democratic, self- } \\
\text { governing management systems" (p. 389). }\end{array}$ \\
\hline $\begin{array}{l}\text { Scott et al. } \\
(2012)\end{array}$ & $\begin{array}{l}\text { Entrepreneurship } \\
\text { Theory and Practice }\end{array}$ & Single case study & South Africa: Avon & $\begin{array}{l}\text { Emancipation can be both a motivation and an outcome for women } \\
\text { entrepreneurs in Africa. Entrepreneurship can be a means for } \\
\text { women to escape or mitigate patriarchal domination, reduce } \\
\text { impoverishment, and increase empowerment. }\end{array}$ \\
\hline $\begin{array}{l}\text { Marti et al. } \\
(2013)\end{array}$ & $\begin{array}{l}\text { Journal of Business } \\
\text { Venturing }\end{array}$ & $\begin{array}{l}\text { Ethnography; interviews, } \\
\text { archival sources }\end{array}$ & Bariloche, Argentina & $\begin{array}{l}\text { Emancipation is part of a broad conception of entrepreneuring which } \\
\text { departs from traditional views of opportunity exploration and } \\
\text { exploitation and organizational emergence. }\end{array}$ \\
\hline $\begin{array}{l}\text { Verduijn \& } \\
\text { Essers (2013) }\end{array}$ & $\begin{array}{l}\text { Entrepreneurship \& } \\
\text { Regional Development }\end{array}$ & $\begin{array}{l}\text { Deconstruction of "life stories" } \\
\text { and discussion around themes; } \\
8 \text { interviews }\end{array}$ & $\begin{array}{l}\text { Netherlands: women ethnic } \\
\text { minority entrepreneurs }\end{array}$ & $\begin{array}{l}\text { Emancipation is a theme within dominant discourse about } \\
\text { entrepreneurship; the dominant discourse is subject to challenge } \\
\text { and critique by deconstruction. }\end{array}$ \\
\hline $\begin{array}{l}\text { Jennings et al. } \\
(2016)\end{array}$ & $\begin{array}{l}\text { Entrepreneurship } \\
\text { Theory and Practice }\end{array}$ & $\begin{array}{l}\text { Hypothesis tests (multivariate } \\
\text { regression); } 163 \text { survey } \\
\text { responses; } 25 \text { interviews }\end{array}$ & $\begin{array}{l}\text { Alberta, Canada: SME } \\
\text { owner-managers (men and } \\
\text { women) }\end{array}$ & $\begin{array}{l}\text { "Behavioural emancipation": } \\
3 \text { sets of quantitative indicators of extent to which operating models } \\
\text { depart from established corporate practices. }\end{array}$ \\
\hline
\end{tabular}


The seven empirical articles in Table 7 featured several recurring themes including liberation from social order, women in developing countries, ethnic minority women in developed countries, and social entrepreneurship.

Goss et al. (2011) argued that the Rindova et al. (2009) assertions about liberation from preexisting constraints were lacking in specificity; the entrepreneuring-asemancipation perspective is missing conception of constraint as a process, and elucidates neither the nature of constraint nor the process through which individuals strive to remove it. They develop the notion of power rituals (Collins, 2004; Summers-Effler, 2002) to establish a "practice-based" understanding of power that focuses on what actors concretely do, think and feel. Power-as-practice can be emancipating.

Mair et al. (2012) used content and cluster analysis on a global sample of 200 social entrepreneurial organizations to develop a typology of social entrepreneuring models. The purpose of their article was to identify and characterize stylized types of entrepreneuring models that exist in the field of social entrepreneurship. For Mair et al. (2012), emancipation is "the transformative ambition that characterize[s] social entrepreneurship" (p. 353).

Pless \& Appel (2012) develop a single case study of an entrepreneurial effort that brings "about new economic, social, institutional and cultural environments through the actions of an individual or a group of individuals" (Rindova et al., 2009, p. 477). In the Pless \& Appel (2012) case, breaking free of constraints and authoring new governance systems are both central to implementing social change through social entrepreneurship.

Scott et al. (2012) proposed "the project of determining whether entrepreneurship 
can be emancipatory in the sense suggested by Rindova, Barry, and Ketchen: 'the act of setting free from the power of another"' (p. 547). They conclude that entrepreneurship can be emancipatory: "The Avon system does seem to provide an emancipatory avenue for poor women in South Africa, enabling some to lift themselves out of poverty, and inspiring many with self-confidence and hope" (p. 563). Entrepreneurship can be a means for women to escape or mitigate patriarchal domination, reduce impoverishment, and increase empowerment.

Marti et al. (2013) examined how "a local community composed of powerless people develop an entrepreneurial culture through working interactions and relationships with external actors" (p. 11), and found that "communities can lead to the creation of new cultures, new relationships, and new 'emancipatory objects' available to the community members" (p. 12).

Verduijn \& Essers (2013) was an empirical multiple-case study contrasting the perspectives of two groups: first, of female ethnic minority entrepreneurs in the Netherlands, and second, employees of organizations that promote and support entrepreneurship in the Netherlands. They situate emancipation among the dominant assumptions of entrepreneurship discourse, along with entrepreneurship as "something 'good' worthy of being stimulated” (p. 613). They write (p. 626): “[That] entrepreneurial efforts indeed seem to 'elevate' (emancipate) individuals ... is a dominant assumption in the standing entrepreneurship literature and popular entrepreneurship discourse, and the myth we are disputing." The authors deconstruct this dominant discourse to identify and discuss areas of disagreement between the two groups. 
Jennings et al. (2016) examined mainstream entrepreneurs in a developed economy to investigate the emancipation perspective's broader relevance beyond the marginalized groups emphasized in prior research. Jennings et al. emphasized the authoring element of entrepreneuring through the extent to which enacted practices depart from the constraints previously in place. They describe three sets of indicators of behavioural emancipation, operationalized as departure from behavioural norms of the traditional workplace in a developed economy: (1) working less than 40 hours per week, (2) self-imposed limits on business-related activity, and (3) minimizing work-to-family interference.

None of the empirical articles reviewed in Table 7 had operationalized the emancipation constructs in a form suitable for an event study. Because the prior operationalizations were not readily adaptable to the research question and methods of this thesis, developing an event study operationalization of the Rindova et al. (2009) emancipation constructs is an important component of the research method described in chapter 3 .

Table 8 is a summary of which journals have published empirical studies about entrepreneuring as emancipation. The last column of the table reports the journal rank, according to the 2016 interim journal review of the Australian Business Dean's Council. All five journals are ranked $\mathrm{A}^{*}$ or $\mathrm{A}$ - the highest of the four quality ranks awarded by the review, representing approximately the top $5 \%$ to $7 \%$ of all management journals, and the next $15 \%$ to $25 \%$ of management journals, respectively. 
Table 8: Journals publishing empirical studies about entrepreneuring as emancipation

\begin{tabular}{lclc}
\hline Journal & $\begin{array}{c}\text { Count of } \\
\text { articles }\end{array}$ & Citations to articles & Journal Rank \\
\hline Entrepreneurship: Theory and Practice & 3 & $\begin{array}{l}\text { Datta \& Gailey (2012) (*) } \\
\text { Scott et al. (2012) } \\
\text { Jennings et al. (2016) }\end{array}$ & A $^{*}$ \\
\hline Journal of Business Ethics & 2 & $\begin{array}{l}\text { Mair et al. (2012) } \\
\text { Pless \& Appel (2012) }\end{array}$ & $\mathrm{A}$ \\
\hline Entrepreneurship \& Regional Development & 1 & Verduijn \& Essers (2013) & $\mathrm{A}$ \\
\hline Journal of Business Venturing & 1 & Marti et al. (2013) & $\mathrm{A}^{*}$ \\
\hline Organization Studies & 1 & Goss (2011) & $\mathrm{A}^{*}$ \\
\hline
\end{tabular}

The high quality ranking of journals publishing empirical studies about entrepreneuring as emancipation - three $\mathrm{A}^{*} \mathrm{~s}$, two As, and no Bs or Cs - implies that the emancipatory perspective is perceived as legitimate by management publishers and reviewers, and relevant to readers of high-prestige management journals.

Perhaps surprisingly, possible connections between emancipation and business ecosystems are unexplored in the published research literature on entrepreneuring as emancipation. The next section reviews the published literature on business ecosystems.

\subsection{Business ecosystems}

James Moore's (1993) award winning Harvard Business Review article, "Predators and prey: A new ecology of competition," introduced the business ecosystem concept into management discourse and argued that modern businesses reside not within a single industry sector but rather within a business ecosystem that crosses multiple industries. In subsequent works, Moore has described business ecosystems as "economic [communities] supported by a foundation of interacting organizations and individuals" 
(1996, p. 26), and as "a network of interdependent niches that [can be] occupied by organizations" (2006, p. 34) - with some niches known and some not yet discovered.

Iansiti \& Levien (2004) distinguished between different roles within ecosystems, including keystone organizations, dominators, and niche players. Keystone organizations "aim to improve overall health of their ecosystems by providing a stable and predictable set of common assets ... that other organizations use to build their own offerings" (p. 73). Iansiti \& Levien write (p. 74):

Broadly speaking, an effective keystone strategy has two parts. The first is to create value within the ecosystem. Unless a keystone finds a way of doing this efficiently, it will fail to attract or retain members. The second part ... is to share the value with other participants in the ecosystem. The keystone that fails to do this will find itself perhaps temporarily enriched by ultimately abandoned.

Keystones anchor an ecosystem. However, most firms in an ecosystem are niche players who operate in the shadow of the keystone to provide value creation through specialized complements that are differentiated from those of other niche players in the network.

In contrast, dominators are harmful to the health of an ecosystem. A physical dominator integrates vertically or horizontally to own and directly control greater portions of the network directly; if a physical dominator wrests control by acquiring or competing directly with niche players, an ecosystem cannot emerge or sustain. Likewise, a value dominator leverages it central position to suck value out of an ecosystem, appropriating attractive profits for itself but leaving little or nothing to sustain niche players. If the organizations occupying hub positions at the centre of the network behave as dominators rather than keystones, an ecosystem will not long endure.

\section{Copyright (C) 2018 Ewan Reid}




\subsubsection{Business ecosystems as an organizational form}

Moore (2006) argued that business ecosystems are a distinct organizational form

- a mode of organizing economic production that differs from markets and organizational

hierarchies. Moore (2006, p. 31) writes:

For more than sixty years, markets and hierarchies have dominated our thinking about economic organization... A third form, the ecosystem organizational form, has now become so important in practice that it should be accorded equal recognition in theory and policy-making. Markets, hierarchies and ecosystems are the three pillars of modern business thinking.

Table 9 compares Moore's explanations of the three organizational forms of markets, hierarchies, and business ecosystems.

Table 9: Markets, hierarchies, and business ecosystems (from Muegge, 2011a, p. 86; adapted from Moore, 2006)

\begin{tabular}{|c|c|c|c|}
\hline \multirow[b]{2}{*}{ Key Features } & \multicolumn{3}{|c|}{ Forms } \\
\hline & Market & Hierarchy & Business ecosystem \\
\hline Function & $\begin{array}{l}\text { Facilitate } \\
\text { transactions for } \\
\text { goods }\end{array}$ & $\begin{array}{l}\text { Facilitate control over } \\
\text { activities that produce } \\
\text { goods }\end{array}$ & $\begin{array}{l}\text { Facilitate coordination of innovation in goods } \\
\text { and the activities that produce them } \\
\text { Facilitate managed co-evolution of the } \\
\text { complex web of markets and hierarchies }\end{array}$ \\
\hline $\begin{array}{l}\text { Ideal } \\
\text { relationships } \\
\text { sought }\end{array}$ & $\begin{array}{l}\text { Perfectly } \\
\text { transparent } \\
\text { transactions }\end{array}$ & Perfect control & Perfect co-evolution of innovation \\
\hline $\begin{array}{l}\text { Levels of } \\
\text { analysis to judge } \\
\text { performance }\end{array}$ & $\begin{array}{l}\text { Goods and } \\
\text { services }\end{array}$ & Tasks and activities & A multitude of contributors \\
\hline Guidance & $\begin{array}{l}\text { The invisible hand } \\
\text { of the market } \\
\text { (Smith, 1776) }\end{array}$ & $\begin{array}{l}\text { The visible hand of the } \\
\text { professional manager } \\
\text { or entrepreneur } \\
\text { (Chandler, 1977) }\end{array}$ & The guiding hand of community leaders \\
\hline
\end{tabular}

\subsubsection{Related ideas}

Moore (2006) cited and drew on a broad set of "related ideas" (p. 36) from scholarly research and practice in the domains of business strategy, marketing, research 
and development and design of products and services, and law. Table 10 is a summary of prior ideas most relevant here to the business ecosystem organizational form, each of which are further explained in the following paragraphs, organized by domain of research and practice.

Table 10: Subset of related ideas that influenced Moore (2006)

\begin{tabular}{|c|c|c|}
\hline Domain & Related ideas in research and practice & Sources cited by Moore \\
\hline \multirow[t]{2}{*}{$\begin{array}{l}\text { Business } \\
\text { Strategy }\end{array}$} & $\begin{array}{l}\text { Collaboration outside of traditional structures; } \\
\text { complementors; co-opetition; }\end{array}$ & Brandenburger \& Nalebuff (1996) \\
\hline & $\begin{array}{l}\text { An extended "ecosystem for wealth creation" in } \\
\text { developing countries serves the world's materially } \\
\text { poorest citizens }\end{array}$ & Prahalad (2005) \\
\hline Marketing & Marketing complementary products and services & Moore (1999) \\
\hline \multirow{4}{*}{$\begin{array}{l}\text { Research and } \\
\text { development, } \\
\text { and design of } \\
\text { products and } \\
\text { services }\end{array}$} & $\begin{array}{l}\text { Modularity of product architectures, organizations, and } \\
\text { industrial economies }\end{array}$ & Baldwin \& Clark (2000) \\
\hline & $\begin{array}{l}\text { Open source software, peer production, distributed } \\
\text { creativity }\end{array}$ & $\begin{array}{l}\text { Raymond (2001) } \\
\text { Weber (2004) }\end{array}$ \\
\hline & $\begin{array}{l}\text { Democratizing innovation; user innovation; community } \\
\text { innovation }\end{array}$ & von Hippel (2005) \\
\hline & Open innovation & Chesbrough (2003) \\
\hline \multirow[t]{2}{*}{ Law } & \multirow{2}{*}{$\begin{array}{l}\text { Peer production; legal and regulatory barriers to the } \\
\text { most open of the business ecosystem forms }\end{array}$} & Benkler (2002) \\
\hline & & Lessig (2004) \\
\hline
\end{tabular}

In the domain of business strategy, Brandenburger \& Nalebuff (1996) had used game theory to develop a set of guidelines to facilitate the explanation of a given business strategy. Co-opetition, a portmanteau of cooperation and competition, refers to informal collaboration between firms which can include elements of competition and collaboration as deemed beneficial to each firm. Complementor refers to a firm that adds value to a mutual customer through the sale of a product or service complementary to another firm's offerings to those customers. Prahalad (2005), examining the businesses that serve 
the world's materially poorest citizens, had described "the symbiotic nature of the relationships between various private sector and social institutional players that can lead to a rapid development of markets" (p. 63). These strategic ideas all feature within a business ecosystem: participants compete over products and services while cooperating around shared goals and complementing the offers of other participants.

In the domain of marketing, Geoffrey Moore (a different author, not to be confused with James Moore) had previously described a chasm between early adopters and pragmatists in the technology adoption life-cycle (Moore, 1999). Crossing the chasm to the mainstream market depends, in part, on the availability of the right complements demanded by pragmatic users. In a business ecosystem, these complements can profitably be provided by specialized niche players, enabling the keystone to focus on maintaining the core platform and on orchestration of ecosystem innovation - what Moore (2006) had called "the guiding hand of community leaders" in Table 9.

In the domain of research and development and product and service design, Baldwin \& Clark (2000) had argued that specialization of firms is enabled by architectural modularity - "a nested hierarchical structure of interrelationships among the primary elements of [a] set [of parameters, tasks, or people]" (p. 11); their field setting was the computer industry, which had evolved from integral mainframes in the 1960s dominated by IBM, to the modular personal computers supplied by the dis-aggregated "Wintel" PC ecosystem in the 1990s (Moore, 1993). Raymond (2001) contrasted two software development models: a cathedral model in which incremental code updates are available only to developers between major releases, and a bazaar model in which all 
developments are continually available; Moore (2006) observed that innovation within an ecosystem often resembled the bazaar model. Weber (2004) explained successful open source software development as a rational economic paradigm where contributors enjoy private benefits from their contributions. von Hippel (2005) argued that innovation is increasingly democratized: through improvements in related technologies, users can conduct their own user innovations; sharing these user innovations with other users and firms enables community innovation. Chesbrough (2003) argued that a new paradigm of open innovation had emerged to displace the traditional internally-focused closed innovation processes of industrial R\&D laboratories; firms utilizing open innovation leverage both internal and external sources of ideas, and find novel ways to benefit from ideas that they choose not to develop internally. Moore (2006) enfolded all of these R\&D ideas - modularity, the bazaar development model, private benefits from contribution, user and community innovation, and open innovation - as features of the business ecosystem organizational form.

In the domain of law, Benkler (2002) proposed the notion of commons-based peer production as an emerging new third mode of production different from production by employees and production by firms - the two modes of production traditionally recognized in regulation. Lessig (2004) described how expanding copyright power can constrain and stifle some forms of innovation except at incumbent firms controlling intellectual property portfolios. The business ecosystem organizational form provided an alternative setting for innovators to incrementally build on the prior innovations of others. 


\subsubsection{Classical view of markets and hierarchies}

The business ecosystem organizational form of Moore (2006) was both a departure from and an extension of the orthodox distinction between markets and hierarchies. Coase (1937) had considered the conditions under which an entrepreneur would rather hire an employee than contract out in the marketplace for a service to be performed. According to Coase, a firm is "the system of specialized relationships which comes into existence when the direction of resources is dependent on an entrepreneur [rather than the price mechanism]"' (p. 393). Firms exist because market transactions have costs: "A firm will tend to expand until the costs of organizing an extra transaction within the firm become equal to the costs of carrying out the same transaction by means of an exchange on the open market or costs of organizing in another firm” (p. 395).

Oliver Williamson integrated the notion of transaction costs into organization theory - a perspective now called transaction cost economics (TCE). Williamson (1981) examined which activities should be performed within the firm and why, and the manner in which human assets are organized. Williamson (1985) further developed the TCE perspective: "The economic institutions of capitalism have the main purpose and effect of economizing on transaction costs" (p. 17). According to Scott \& Davis (2007),

"Transaction cost analysis has been the most influential import of economic thinking into organization theory, and the influence has been mutual."

Moore (2006) argued that business ecosystems operate under a different logic with emphasis on the positive and differentiating outcomes of innovation rather than a narrow and exclusive focus on the lowest cost of transactions. 


\subsubsection{Refinements and extensions}

Following the Moore (2006) conceptualization of business ecosystems as an organizational form, management scholars continued to develop the business ecosystem concept. This subsection reviews recent refinements and extensions in four themes: technology entrepreneurship, innovation processes, platforms, and business ecosystems as a perspective on management strategy.

On the theme of technology entrepreneurship, Muegge (2011b) "introduces a systems perspective on community-developed platforms and the institutions that structure participation by individuals and companies" (p. 4), where a business ecosystem may be one component of a larger field setting. Bailetti (2012) identified business ecosystems as an enabler of rapid globalization: a born global technology entrepreneur seeking to globalize early and rapidly should "increase legitimacy by ... leveraging mentors and advisors to build an ecosystem around the startup" (p. 7). Bailetti \& Bot (2013) described how the Lead To Win job-creation engine is organized as a business ecosystem and argued that "the architecture of a job-creation engine fueled by technology entrepreneurs is important and that it should be made visible to the stakeholders" (p. 31). Muegge (2013, pp. 5-6) argued that participation in business ecosystems may be a partial remedy to the problems faced today by technology entrepreneurs:

By building products and services on platform assets developed by others, a technology entrepreneur can focus $R \& D$ effort on building differentiating capability. By engaging communities of passionate people, a technology entrepreneur can learn more effectively about individual wants and needs, benefit from user innovations, and channel the creative energy of the community towards useful endeavours. By operating a business within a networked ecosystem of interdependent and codependent businesses with partially aligned incentives, a technology entrepreneur can achieve more, 
learn faster, and reach farther than otherwise possible, while sharing some of the risks and costs with others.

Muegge \& Mezen (2017) demonstrated an association between ecosystem participation and business model innovation by early-stage technology entrepreneurs: "More intense participation in the ecosystem is associated with higher business model differentiation, sophistication, and extent of change" (p. 157). For technology entrepreneurs, business ecosystems can thus be an enabler, a legitimizer, a differentiator and an impetus for change creation.

On the theme of platforms, Gawer (2014, p. 1239) writes:

platforms can be usefully conceptualized as evolving organizations or metaorganizations that: (1) federate and coordinate constitutive agents who can innovate and compete; (2) create value by generating and harnessing economies of scope in supply or/and in demand; and (3) entail a modular technological architecture composed of a core and a periphery.

This definition sought to unify the engineering notion of platforms as architectures of modular components with the economics notion of platforms as multi-sided markets either of which can anchor a business ecosystem. Gawer \& Cusumano (2014) identified two types of platforms, internal and external, with external platforms being open to outside firms and distinguished by the potential for network effects. External, or industry, platforms "provide the technological foundation at the heart of innovative business ecosystems" (p. 428). They also assert that "platform leaders ... must think broadly about potential competitors from adjacent markets as well as manage the evolution of their technology, business models, ecosystem partnerships, and marketing capabilities" (p. 428). Thomas et al. (2014) "elaborate on the theoretical logics of 
leverage and architectural openness" (p. 47) and assert that platforms combine elements of three leverage rationales: production, innovation, and transaction. "The platform ecosystem stream views the platform as a hub or a central point of control within a technology-based business system" (p. 53). Thus platforms of various forms can be the locus of innovation anchoring a business ecosystem.

On the theme of innovation processes, Baldwin \& von Hippel (2011) assess the economic viability of innovation by producers relative to two increasingly important alternative models: user innovations by single users and open collaborative innovation by groups of individuals. Through formal cost-benefit analysis, they demonstrate that the open collaborative innovation and user innovation processes that anchor many business ecosystems are increasingly viable as the costs of design and communication drop.

Adner (2017) develops an alternative conceptualization of ecosystems as a perspective on management phenomena rather than an organizational form. An ecosystem perspective on strategy emphasizes interdependence between actors, and the allocation of resources in the context of interdependence: "It is a distinct complement to established schools of thought around competitive strategy and corporate strategy" (p. 40). Adner develops an ecosystem-as-structure approach with an activity-centric view of interdependence, contrasting with the ecosystem-as-affiliation approach used by Moore (1996) and Iansiti \& Levien (2004) and much of the literature, "which sees ecosystems as communities of associated actors defined by their networks and platform affiliations" ( $p$. 40). While distinct from Moore's view of an ecosystem as an organizational form, it is relevant here as explained by Adner (2017, p. 44): 
The two perspectives follow opposite directions of strategy construction: The ecosystem-as-affiliation approach begins with the actors (usually defined by their ties to a focal actor), considers the links among them, and ends with the possible value propositions and enhancements that the ecosystem can generate. In contrast, the ecosystem-as-structure view begins with the value proposition, considers the activities required for its materialization, and ends with the actors that need to be aligned.

Adner defines ecosystem as "the alignment structure of the multilateral set of partners that need to interact in order for a focal value proposition to materialize" (p. 40) where alignment structure "refers not only to compatible incentives and motives but also raises the question of actors' consistent construal of the configuration of activities" (p. 42). Adner defines ecosystem structure as "the alignment of activities, actors, positions, and links" (p. 40). Adner defines ecosystem strategy as "the way in which a focal firm approaches the alignment of partners and secures its role in a competitive ecosystem" ( $\mathrm{p}$.

47). Ecosystem roles include leader and follower (p. 48):

The ecosystem leader is the firm to whose vision of structure and roles others defer. It sets, and often enforces, the governance rules, determines timing, and often reaps the lion's share of gains after the ecosystem is aligned. An ecosystem follower is a firm that agrees to these terms, and cedes the leadership role. Successful leadership is thus contingent on willing followership.

"Participating actors in the system have a joint value creation effort as a general goal" (p. 43), thus "the defining attribute of partners is that they are actors on whose participation the value proposition depends, regardless of whether or not they have direct links to the focal firm" (p. 43). Partners may adopt different strategies and hold differing perceptions about other actors - thus partner alignment is a central feature of the ecosystem perspective (p. 46): 
When a value proposition depends on a shift in ecosystem structure, the additional strategic question that is raised concerns alignment: How will the innovator create the impetus for other actors, who may not be directly linked to the innovator, to change?

Leaders and followers can resolve misalignment and bring about alignment by adjusting roles: "Who will accept the role of follower and agree to act in accordance with the leader's plan? What rivalries need to be managed within and across ecosystems?" (p. 47).

Several similarities are evident across the four themes reviewed in this subsection and the prior literature on business ecosystems. Regarding the different roles within an ecosystem, the Adner (2017) notion of leaders and follows compares with the Gawer (2014) notion of platform leaders and the Iansiti \& Levien (2004) notion of keystones and niche players. Regarding the central feature anchoring an ecosystem, the Adner (2017) notion of focal value proposition compares with the Moore (2013) notion of shared vision, and the various platform constructs in the platforms literature (e.g., Gawer, 2014). Regarding prescriptive advice for ecosystem participants, the Adner (2017) notion of ecosystem strategy compares with the Gawer \& Cusumano (2014) notion of platform strategy, and the Muegge \& Mezen (2017) findings that "entrepreneurs participating more intensely in the ecosystem report a greater breadth of benefits" (p. 157), with greater business model differentiation, sophistication, and extent of change. Moore (2013), Gawer (2014), Thomas et al. (2014), Adner (2017) and others have recently made progress bridging differences in language and approach with synthesis, categorization, and theorizing about connections. Perhaps surprisingly, the notion of emancipation is not developed in the business ecosystems literature. 


\subsection{Linking business ecosystem and emancipation constructs}

This section brings together ideas from the emancipation perspective on entrepreneuring from section 2.1 with ideas from business ecosystems as an organizational form from section 2.2 to identify and explore possible conceptual and theoretical connections. The following three subsections each examine connections between business ecosystems and one of the three core elements of the Rindova et al. (2009) emancipation perspective on entrepreneuring: seeking autonomy, authoring, and making declarations, respectively. This is followed by a fourth subsection that reconsiders the business ecosystem organizational form as a source of constraints.

\subsubsection{Seeking autonomy and business ecosystems}

In the emancipation perspective on entrepreneuring, seeking autonomy refers to the perceived need of the entrepreneur to break free of or break up a perceived constraint in the environment, which could be of an intellectual, psychological, economic, social, institutional, or cultural nature (q.v., subsection 2.1.1). Seeking autonomy is thus the impetus for entrepreneuring. Possible connections to ideas in the business ecosystems literature could therefore include constraints imposed by other organizational forms, or ways in which aspects of the business ecosystem organizational form could be a means for breaking free of or breaking up perceived constraints.

Table 11 is a summary of some possible connections between seeking autonomy and the themes within the literature on business ecosystems. 
Table 11: Connections between seeking autonomy and business ecosystems

\begin{tabular}{|c|c|c|}
\hline Domain or theme & Connection with business ecosystem organizational form & Source \\
\hline \multirow[t]{2}{*}{ Business Strategy } & \multirow{2}{*}{$\begin{array}{l}\text { Seeking to break free of the constraint of poverty through } \\
\text { interactions with external actors and communities }\end{array}$} & Prahalad (2005) \\
\hline & & Marti et al. (2013) \\
\hline $\begin{array}{l}\text { Research and } \\
\text { development; design of } \\
\text { products and services }\end{array}$ & $\begin{array}{l}\text { Integral architectures (that are not modular) impose constraints } \\
\text { which can be broken free from with specialization in an } \\
\text { ecosystem enabled by modularity }\end{array}$ & $\begin{array}{l}\text { Baldwin \& Clark } \\
(2000)\end{array}$ \\
\hline \multirow[t]{2}{*}{ Law } & \multirow{2}{*}{$\begin{array}{l}\text { Excessive intellectual property rights can constrain shared } \\
\text { collaboration and learning; peer production in ecosystems can } \\
\text { be a means of breaking free }\end{array}$} & Benkler (2002) \\
\hline & & Lessig (2004) \\
\hline $\begin{array}{l}\text { Technology } \\
\text { Entrepreneurship }\end{array}$ & $\begin{array}{l}\text { Technology entrepreneurs may be constrained by limited } \\
\text { resources, limited local reach, limited prior experience, or } \\
\text { limited access to partners and capabilities; business } \\
\text { ecosystems may be a partial remedy with which to break free } \\
\text { from, or break up, these constraints }\end{array}$ & Muegge (2013) \\
\hline Innovation Processes & $\begin{array}{l}\text { Limitations of producer innovation can be constraints; } \\
\text { user innovation and open collaborative innovation can be the } \\
\text { means to break free from, or break up, these constraints }\end{array}$ & $\begin{array}{l}\text { Baldwin \& von } \\
\text { Hippel (2011) }\end{array}$ \\
\hline $\begin{array}{l}\text { Ecosystems as a } \\
\text { perspective }\end{array}$ & $\begin{array}{l}\text { An entrenched and "taken for granted" value proposition can } \\
\text { be constraining for an innovator seeking to establish a new } \\
\text { value proposition; enacting an ecosystem strategy that entails } \\
\text { a shift in ecosystem structure and provides the impetus for } \\
\text { other actors in the ecosystem to change their behaviours can } \\
\text { be a means to break free from, or break up, this constraint }\end{array}$ & Adner (2017) \\
\hline
\end{tabular}

Prahalad (2005) argued that poverty reduction can be achieved by serving the world's materially poorest citizens through an extended ecosystem for wealth creation. Bottom-of-the-pyramid thinking links the strategy theme of the business ecosystems literature to various ideas in the emancipation literature including power-as-practice (Goss et al. 2011), social entrepreneurship (Mair et al. 2012), social change (Pless \& Appel, 2012) and poverty reduction (Scott et al., 2012). Most strikingly, Prahalad's thinking aligns with the Marti et al. (2013) findings that powerless people can be emancipated through interactions with external actors and communities.

For technology entrepreneurs, Muegge (2013) argues that business ecosystems can be a partial remedy for at least three common challenges (p. 5): 
First, with limited resources, confronting all of the well-known liabilities of attempting something new, success often depends on access to specialized knowledge and resources that lie outside the entrepreneur's ownership or control. In a hyper-competitive environment, buying or building may not be attractive or even viable options. Second, success often critically depends on the innovations and actions of others who complement the entrepreneur's offer. Prior experience with the customer and supplier relationships of a traditional supply chain is inadequate preparation for the challenges of managing complementors. Third, these critical assets and complementorsas well as suppliers, customers, and competitors - can be located anywhere in the world. The environments in which technology entrepreneurs operate are at once global and densely interconnected.

Following this argument, business ecosystems are a means for technology entrepreneurs to break free of constraints arising from scarce resources, technological limitations, and lack of legitimacy and status. Likewise, for technology entrepreneurs, business ecosystems can be an enabler of rapid globalization (Bailetti, 2012) to break free from constraints of locality, faster learning (Bailetti \& Bot, 2013) to break up constraints of limited knowledge and know-how, and accelerated business model discovery (Muegge \& Mezen, 2017) to break free of the conventional status quo for doing business.

Other perceived constraints follow from the limitations of hierarchies and markets, and from traditional ways of organizing production. The constraints imposed by integral designs may be broken up by modularity (Baldwin \& Clark, 2000), enabling specialization and differentiation by niche players within an ecosystem (Iansiti \& Levien, 2004). The constraints imposed by traditional intellectual property rights (Lessig, 2004) may be broken up by peer production (Benkler, 2002), open source licensing and bazaar development processes (Raymond, 2001; Weber, 2004), collaborative innovation (von Hippel, 2005; Baldwin \& von Hippel, 2011), and platform innovation (Gawer, 2014; 
Gawer \& Cusumano, 2014; Thomas et al. 2014) within business ecosystems. The constraints of an entrenched value proposition can be broken up by re-configuring an ecosystem structure around a new focal value proposition (Adner, 2017).

Thus the seeking autonomy construct of the emancipatory perspective is closely connected with various ideas in the business ecosystems literature, including breaking free of constraints imposed by markets and hierarchies, traditional ways of organizing production, and common challenges faced by technology entrepreneurs.

\subsubsection{Authoring and business ecosystems}

In the emancipation perspective on entrepreneuring, authoring refers to taking ownership by defining relationships, arrangements, and rules of engagement, and changing positions of power (q.v., subsection 2.1.2). According to Rindova et al. (2009), entrepreneuring individuals undertake authoring actions to organize resource exchanges; the new rules of engagement with key resource providers thus reflect the change-creating intent of the entrepreneuring individual, and organizational arrangements can be designed to preserve emancipatory potential. Possible connections to ideas in the business ecosystems literature could therefore include (1) roles and relationships with other ecosystem members, (2) organizational arrangements to preserve emancipatory potential, (3) the rules of engagement with ecosystem members and ecosystem resources that reflect change-creating intent, and (4) shifts in ecosystem structure that change positions of power.

Table 12 is a summary of some possible connections between authoring and the themes within the literature on business ecosystems.

\section{Copyright (C) 2018 Ewan Reid}


Table 12: Connections between authoring and business ecosystems

\begin{tabular}{|c|c|c|}
\hline Domain or theme & Connection with business ecosystem organizational form & Source \\
\hline Business Strategy & $\begin{array}{l}\text { Keystone organization's crucial role in business ecosystem } \\
\text { defines rules of engagement with key resource providers to } \\
\text { reflect change-creating intent }\end{array}$ & Iansiti \& Levien (2004) \\
\hline Marketing & $\begin{array}{l}\text { Complementors enable keystone firms to sit at the core of an } \\
\text { ecosystem which is an organizational arrangement which } \\
\text { could preserve emancipatory potential }\end{array}$ & Moore (1999) \\
\hline $\begin{array}{l}\text { Research and } \\
\text { development; } \\
\text { design of products } \\
\text { and services }\end{array}$ & $\begin{array}{l}\text { Open, user, community and democratized innovation can be } \\
\text { leveraged to define rules of engagement to maintain change } \\
\text { creating intent }\end{array}$ & $\begin{array}{l}\text { Raymond (2001) } \\
\text { Weber (2004) } \\
\text { von Hippel (2005) } \\
\text { Chesbrough (2003) }\end{array}$ \\
\hline $\begin{array}{l}\text { Technology } \\
\text { Entrepreneurship }\end{array}$ & $\begin{array}{l}\text { Benefits from user innovation as selected organizational } \\
\text { arrangement can provide access to resources or global reach } \\
\text { which could facilitate the change-creating intent }\end{array}$ & $\begin{array}{l}\text { Muegge (2013) } \\
\text { Bailetti (2012) }\end{array}$ \\
\hline $\begin{array}{l}\text { Innovation } \\
\text { Processes }\end{array}$ & $\begin{array}{l}\text { Open, user, community and democratized innovation are } \\
\text { alternative arrangements to help to realize change creating } \\
\text { intent }\end{array}$ & $\begin{array}{l}\text { Baldwin \& von Hippel } \\
\text { (2011) }\end{array}$ \\
\hline Platforms & $\begin{array}{l}\text { Industry platforms at the heart of innovative business } \\
\text { ecosystems can be the organizational arrangement which } \\
\text { allows keystones to preserve emancipatory potential and } \\
\text { niche players to execute their change-creating intent }\end{array}$ & $\begin{array}{l}\text { Gawer \& Cusumano } \\
(2014)\end{array}$ \\
\hline \multirow[t]{2}{*}{$\begin{array}{l}\text { Ecosystems as a } \\
\text { perspective }\end{array}$} & $\begin{array}{l}\text { Activities as the discrete actions undertaken in order for the } \\
\text { value proposition to materialize is connected with change- } \\
\text { creating intent and maintenance of the emancipatory potential }\end{array}$ & Adner (2017) \\
\hline & $\begin{array}{l}\text { To enable partner alignment - a critical feature of the } \\
\text { business ecosystem perspective - rules of engagement with } \\
\text { key resources providers must preserve change creating intent }\end{array}$ & \\
\hline
\end{tabular}

Regarding roles and relationships with ecosystem actors, Iansiti \& Levien (2004) asserted that "stand alone strategies do not work when your company's success depends on the collective health of the organizations that influence the creation and delivery of your product. Knowing what to do requires understanding the ecosystem and your organization's role in it" (p. 69). Resource flows within an ecosystem are not limited to dyadic exchange relationships as assumed by Rindova et al. (2009), but can also include complex resource cycles and unequal exchanges (e.g., Muegge, 2011b), collaborative community innovation (e.g., von Hippel, 2005; Baldwin \& von Hippel, 2011) and 
innovation around shared platforms of various form (e.g., Gawer \& Cusumano, 2014).

Organizational arrangements to preserve emancipatory potential include the existence of profitable complementors (Brandenburger \& Nalebuff, 1996; Moore, 1999), which enables ecosystem keystones (Iansiti \& Levien, 2004) to focus on maintaining the core platform and on orchestration of ecosystem innovation (Moore, 2006, 2013). "By engaging communities of passionate people, a technology entrepreneur can ... benefit from user innovations" (Muegge, 2013, p. 5). Guiding the technology leadership of platform innovation protects the interests of the platform leader (Gawer, 2014; Gawer \& Cusumano, 2014; Thomas et al. 2014).

New rules of engagement with ecosystem members and ecosystem resources can include collaborative R\&D processes such as open source development (Raymond, 2001; Weber, 2004), peer production (Benkler, 2002), and collaborative innovation (von Hippel, 2005; Baldwin \& von Hippel, 2011), orchestrated by the "guiding hand" of the keystone.

Shifts in ecosystem structure that change positions of power are an aspect of ecosystem strategy (Adner, 2017), especially by the ecosystem leader who is concerned with partner alignment and creating impetus for other actors to follow the leader's change-creating intent.

Thus the authoring construct of the emancipatory perspective is closely connected with various ideas in the business ecosystems literature, including ecosystem roles, resource flows, nurturing complementors, platform leadership, collaborative R\&D processes, and ecosystem strategy. 


\subsubsection{Making declarations and business ecosystems}

In the emancipation perspective on entrepreneuring, making declarations refers to unambiguous discursive and rhetorical acts about intended change; theses acts are essential to mobilize support from stakeholders, manage stakeholder interpretations and expectations, and generate change effects (q.v., subsection 2.1.3). According to Rindova et al. (2009), an entrepreneur makes declarations to "position the [entrepreneurial] project in the webs of meaning within which stakeholders interpret the value of products and services" (p. 485). Possible connections to ideas in the business ecosystems literature could therefore include communicating information, signaling intent or commitment, making demands of others, managing expectations, or negotiating leadership roles or positions in the network.

Table 13 is a summary of some possible connections between making declarations and the themes within the literature on business ecosystems.

Table 13: Connections between making declarations and business ecosystems

\begin{tabular}{|c|c|c|}
\hline Domain or theme & Connection with business ecosystem organizational form & Source \\
\hline Business Strategy & $\begin{array}{l}\text { Promoting ecosystem health with predictable assets } \\
\text { addresses intended change which is essential to mobilize } \\
\text { support and generate change effects }\end{array}$ & lansiti \& Levien (2004) \\
\hline $\begin{array}{l}\text { Technology } \\
\text { Entrepreneurship }\end{array}$ & $\begin{array}{l}\text { Channeling the creative energy of the community in an } \\
\text { ecosystem mobilizes support and generate change effects }\end{array}$ & Muegge (2013) \\
\hline $\begin{array}{l}\text { Innovation } \\
\text { Processes }\end{array}$ & $\begin{array}{l}\text { Change in problem field of innovation is essential change } \\
\text { required to mobilize support }\end{array}$ & $\begin{array}{l}\text { Baldwin \& von Hippel } \\
\text { (2011) }\end{array}$ \\
\hline \multirow[t]{2}{*}{$\begin{array}{l}\text { Ecosystems as a } \\
\text { perspective }\end{array}$} & $\begin{array}{l}\text { Ecosystem structure is the alignment of activities, actors, } \\
\text { positions, and links necessary to generate change effects; } \\
\text { alignment can be achieved in part by making declarations }\end{array}$ & Adner (2017) \\
\hline & $\begin{array}{l}\text { Positioning of leaders and followers within an ecosystem can } \\
\text { help to be established through making declarations }\end{array}$ & \\
\hline
\end{tabular}


Iansiti \& Levien (2004) argued that successful companies promote their ecosystem's overall health, mobilizing support and generating change effects. Muegge (2013) argued that a technology entrepreneur in a business ecosystem can mobilize community support to "channel the creative energy of the community towards useful endeavours" (p. 5). Adner (2017) argued that an ecosystem leader communicates the vision of structure and roles to which others defer: "Successful leadership is thus contingent on willing followership" (p. 48). Adner writes (p. 47):

Every firm defines its own ecosystem strategy, which encompasses a view on ecosystem structure, ecosystem roles, and ecosystem risk. Across participants, these strategies can range from consistent to contradictory. The greater the consistency in strategy among the relevant actors, the higher the likelihood that their actions will be convergent, but there is not requirement of consistency. Just as critically, there is no presumption that inconsistency will necessarily be recognized within a given time frame.

Partner alignment is a critical consideration for all participants (p. 47):

In the context of a given firm's ecosystem strategy, partner alignment is assessed relative to the focal firm's ability to bring its partners into the positions and roles that its ecosystem strategy envisions. An approach to partner alignment thus entails, first, recognizing gaps; and second, creating conditions (whether through resource allocation or revision of strategy) for closing these gaps.

Alignment structure "refers not only to compatible incentives and motives but also raises the question of actors' consistent construal of the configuration of activities" (p. 42).

Thus the making declarations construct of the emancipatory perspective is central to the activities of ecosystem leaders and followers to bring about the alignment of ecosystem activities, actors, positions, and links. 
In summary, all three core elements of the Rindova et al. (2009) emancipatory perspective on entrepreneuring appear to have abundant connections to the various ideas and themes prominent in the management literature on business ecosystems, especially for technology entrepreneurs. Nonetheless, these conceptual connections were previously unacknowledged in either literature, and have not been studied empirically.

\subsubsection{Ecosystems constraints}

The previous three subsections have examined the ways in which business ecosystems can be enablers of the three core elements of the emancipation perspective on entrepreneuring. However, the various collaborative aspects inherent in business ecosystems could alternatively be perceived as constraining by some entrepreneurs. Iansiti \& Levien (2004) asserted that stand alone strategies do not work if operating in the context of a business ecosystem. Gawer (2014) stated that "design decisions on technological interfaces, as well as governance decisions, can be expected to have an effect on the platform agents' incentives to collaborate, to innovate, and/or to compete" (p. 1246). Adner (2017) claimed that partners "need to interact in order for a focal value proposition to materialize" (p. 40). Value dominator and physical dominator strategies that could be effective at imposing control within markets and hierarchies, respectively, are ineffective within business ecosystems (Iansiti \& Levien, 2004). For an entrepreneur seeking exclusive control, free from all external pressures, the requirement to collaborate and perhaps compromise may be anathema. 


\subsection{Summary and synthesis of key findings from the literature}

In summary, the salient lessons for this research include the following.

(1) The emancipation perspective on entrepreneuring and business ecosystems are both active areas of management research with articles published in top-ranked journals. Likewise, both concepts are relevant to management practice - particularly technology entrepreneurs seeking to launch and grow new technology businesses.

(2) There are theoretical arguments that business ecosystems may be emancipating, and other theoretical arguments that they are not. A literature review identified no prior research at the intersection emancipation and business ecosystems. The role of business ecosystems - and more generally of role of organizational forms - in the emancipation processes of entrepreneurs is thus far unexplored.

(3) In the corpus of fifty peer-reviewed journal articles (inventoried in Table 6) citing Rindova et al. (2009) and employing the notion of entrepreneuring as emancipation, only seven of these articles were empirical studies of emancipation (summarized in Table 7). There was no method or operational specifications in the prior literature for systematically identifying emancipation events from narrative.

This chapter has reviewed the scholarly literature relevant to the research question and confirmed a gap in the extant literature. The next chapter presents the research design and method. 
Emancipated entrepreneuring in the nascent commercial spaceflight industry: Authoring ecosystems by Branson, Diamandis, and Musk. Copyright (C) 2018 Ewan Reid

\section{Research design and method}

This chapter presents the research design and detailed method to answer the research question posed in chapter 1 . The chapter is structured in seven sections - one section for each step of the research method. Table 14 summarizes the seven steps of the research method, the activities undertaken, and the outcomes of each step.

Table 14: Steps of the research method

\begin{tabular}{|c|c|c|}
\hline Step & Description of activity undertaken & Outcomes \\
\hline $\begin{array}{l}\text { 1. Conceptual } \\
\text { development }\end{array}$ & $\begin{array}{l}\text { Select and/or develop operational frameworks for } \\
\text { emancipation and organizational forms }\end{array}$ & $\begin{array}{l}\text { - Inventory of published articles } \\
\text { citing Rindova et al. (2009) } \\
\text { - Inventory of operational } \\
\text { specifications of emancipation in } \\
\text { the published literature } \\
\text { - Two operational frameworks: } \\
\text { 1) emancipation constructs } \\
\text { 2) organizational forms }\end{array}$ \\
\hline 2. Select cases & $\begin{array}{l}\text { Compile list of candidate entrepreneurs and } \\
\text { ventures. Develop selection criteria. Apply criteria } \\
\text { to select three cases and sources material. }\end{array}$ & $\begin{array}{l}\text { - List of candidate entrepreneurs } \\
\text { - Set of selection criteria } \\
\text { - Selection of } 3 \text { cases and sources }\end{array}$ \\
\hline $\begin{array}{l}3 . \text { Refine and } \\
\text { validate coding }\end{array}$ & $\begin{array}{l}\text { Apply the operational frameworks in a set of pilot } \\
\text { exercises to refine and validate the codes and } \\
\text { approach, and the selection of tools and sources }\end{array}$ & $\begin{array}{l}\text { - Coding pilot \#1 (manual coding of } \\
\text { a press release) } \\
\text { - NVivo data file configured with } \\
\text { source material ready for coding } \\
\text { - Coding pilot \#2 (NVivo coding of a } \\
\text { press release and sample chapter) }\end{array}$ \\
\hline 4. Incident coding & Code the source material to identify incidents & - NVivo data file with incidents \\
\hline 5. Event coding & Code the incidents to emancipation events & $\begin{array}{l}\text { - NVivo data file with events } \\
\text { - Summary tables of emancipatory } \\
\text { events for each case }\end{array}$ \\
\hline $\begin{array}{l}\text { 6. Organizational } \\
\text { form coding }\end{array}$ & $\begin{array}{l}\text { Code the emancipation events to organizational } \\
\text { forms }\end{array}$ & $\begin{array}{l}\text { - NVivo data file with events } \\
\text { categorized by organizational form } \\
\text { - Summary tables of events and } \\
\text { organizational forms }\end{array}$ \\
\hline $\begin{array}{l}\text { 7. Cross-case } \\
\text { comparison and } \\
\text { explanation-building }\end{array}$ & $\begin{array}{l}\text { Compare the three cases using cross-case } \\
\text { techniques recommended by Yin (2011); develop } \\
\text { explanations of similarities and differences }\end{array}$ & $\begin{array}{l}\text { - Observations and explanations } \\
\text { - Answer to the research question }\end{array}$ \\
\hline
\end{tabular}


It is important to note that several of the major research design decisions, including the selection of NVivo as the tool for analysis, and the use of three rounds of coding, were finalized at step 3 as an outcome of the coding pilots rather than at step 1 with the conceptual development of the operational frameworks.

At the proposal stage of this research, we (the author and the supervisor) had expected to discover and reuse operational specifications of the constructs in the Rindova et al. (2009) emancipation perspective of entrepreneuring from the prior empirical literature. We were surprised to find no prior work that met our particular needs. We concur with Jennings et al. (2016) that "The limited corpus of extant empirical work has primarily been conducted in developing economies" (p. 99), and we further note that studies have typically focused narrowly on a single core element rather than on emancipation more broadly. We also concur with Goss et al. (2011) that the Rindova et al. (2009) assertions about liberation from preexisting constraints are lacking in operational specificity. Thus a significant component of this thesis is the development, validation, and first application of an approach to identify the emancipation events from a narrative (i.e., a book about an entrepreneur and their venture), and formally describe each event in a form amendable to further analysis.

\subsection{Step 1: Conceptual development}

We began with a close examination of the scholarly literature, looking for operational specifications and frameworks to be reused within our own empirical research. We specifically wanted to parse a text about an entrepreneur, identify from the text any occurrences of the three core elements of entrepreneuring, and describe each 
occurrence in a consistent way. Our review included an inventory of fifty articles citing Rindova et al. (2009), previously reported in subsection 2.1.4, and close reading of seven empirical studies about entrepreneuring as emancipation, previously reported in subsection 2.1.5. We located no frameworks in the prior literature that met our needs.

The specification developed here returns to the original definitions of Rindova et al. (2009). We began our conceptual development by borrowing several ideas and definitions of terms from the methodology literature of process theory (Van de Ven et al. 1999; Poole et al. 2000; Van de Ven, 2007):

- Abbot (1984) distinguished between an incident (a raw datum) and an event (a theoretical construct).

- Poole et al. (2000) defined a qualitative datum for an incident as "(1) a bracketed string of words capturing the basic elements of information (2) about a discrete incident or occurrence (the unit of analysis) (3) that happened on a specific date, which is (4) entered as a unique record (or case) in a qualitative data file, and (5) is subsequently coded and classified as an indicator of a theoretical event." (p. $133)$.

- Poole et al. (2000) argued for a common framework to describe events (p. 49) with systematic coding rules that specify the operational steps for classifying incidents into event constructs (p. 163).

- Poole et al. (2000) argued for construction of a data file that systematically presents the events that were observed to occur in the organizational entities being investigated (p. 113). 
These six concepts from the process theory literature - (1) events (the construct of interest), (2) incidents (the data that indicate events), (3) the qualitative datum for an incident (being a passage of text from a source), (4) a common framework (to systematically and consistently describe events), (5) systematic coding rules (that specify how to classify incidents into events), and (6) a data file (to store events and incidents) are the conceptual building blocks of our method and operational specification of the emancipation constructs.

Emancipation events are of three types, corresponding to the three core elements of the Rindova et al. (2009) emancipatory perspective on entrepreneuring: (1) seeking autonomy, (2) authoring, and (3), making declarations.

Seeking autonomy refers to both breaking free of perceived constraints and also breaking up the perceived constraints, which can be intellectual, psychological, economic, institutional, or cultural. Seeking autonomy can be an impetus of entrepreneuring.

Authoring refers to taking ownership by defining relationships, arrangements, and rules of engagement, and changing the positions of power. Authoring reorganizes resource exchanges by positioning the entrepreneurial project in a system of exchange relationships with resource holders.

Making declarations refers to unambiguous discursive and rhetorical acts regarding the actor's intentions to create change. Making declarations manages stakeholder interpretations by positioning the entrepreneurial project in the webs of meaning within which stakeholders interpret the value of products and activities. 
The common framework for describing an event of each type followed from a close reading of Rindova et al. (2009):

- Seeking autonomy (SA): (1) the perceived constraint, (2) breaking free of the perceived constraint (including dreams, desire, passion, intent, and actions), (3) breaking up the perceived constraint.

- Authoring (A): (1) the old status quo to be changed (including relationships, arrangements, norms, rules of engagement, positions of power, and forms of authority), (2) the new arrangement supporting the change-creating intent of the entrepreneuring individual.

- Making declarations (MD): (1) statement of intent to create change, (2) forms of discursive or rhetorical acts, (3) contestations from others, (4) overcoming contestations from others.

To maintain a traceable chain of evidence back to source material - a best practice for case research according to Yin (2014) - each event of all three event types must also reference (i.e., preserve the link back to) the incidents that indicate the event. Each event is identified by a unique name.

Events are indicated by incidents - coded passages of text from primary sources. The qualitative datum for an incident is a referenced passage of text, formally specified as a bracketed string of words about an occurrence of emancipation, excerpted from a source, with a reference to the source and the location of the words within the source. Incidents are subsequently re-coded and classified into emancipation events. 
Several open questions remained at the end of this step, including the precise nature of the data file (e.g., a spreadsheet, a file in a database application, a specialized software application for qualitative data analysis, or something else), the coding rules (e.g., whether incidents and events would be coded simultaneously from the source material in one pass, or whether there would be multiple rounds of coding), and which software applications (if any) would be employed. Also, we were aware of no prior event studies of the emancipation perspective on entrepreneuring, thus the feasibility of applying process theory to this problem space was uncertain. For these reasons, following the advice of Miles \& Huberman (1994), Poole et al. (2000), Van de Ven (2007), Bazeley \& Jackson (2013), and others, we intended to undertake a series of pilot studies with small data sets to refine and validate the over-all approach and to make decisions about these open questions. This refinement and validation occurred in step 3 , after selecting cases in the next step.

\subsection{Step 2: Select cases}

Next, we constructed a list of candidate entrepreneurs, along with information about their space ventures, books written by the entrepreneur, and books written about the entrepreneur. We considered only entrepreneurs who had previously founded and continued to lead organizations in the commercial spaceflight sector, broadly interpreted. The list of candidate entrepreneurs is reported in subsection 4.2 .1 of the results chapter.

We developed two selection criteria to choose our cases from the list of candidates: (1) there exists a recent book about the entrepreneur and their space venture, either authored by the entrepreneur or about the entrepreneur, to provide source material 
for our analysis, and (2) we preferred some variation with respect to the venture's product and service offerings within the domain of commercial spaceflight. After imposing the first criterion, only three candidates remained. Each of the three remaining candidates had very different product or service offerings - one each of space tourism, incentive competitions, and launch services - collectively satisfying the second criterion.

\subsection{Step 3: Refine and validate coding}

Following the recommendations of Poole et al. (2000) and others, we applied the approach and the version 1 operational specifications previously developed in step 1 of the method in a set of exploratory pilot exercises with small data sets to refine and validate the codes and approach, and the selection of tools and sources.

Coding pilot \#1 was comprised of two activities. First, two coders (the author and supervisor), working independently, each examined a "pilot source" - a one-page February 2017 press release from SpaceX - attempting to directly identify and code events from the text of the source document. The first coder (the author), coded the pilot source using NVivo, a software package for qualitative data analysis. The second coder (the supervisor), coded the source manually using a word processor document as the data file. Second, after comparing results, both coders more closely examined the capabilities and limitations of NVivo as a potential fit with the requirements of this research; helpful sources of information included Bazeley \& Jackson (2013), the NVivo documentation, and the Research Support Services staff at the Carleton University Library. The lessons learned from coding pilot \#1 were captured in an 11-page coding pilot \#1 document and enfolded into a revised operational specification (version 2). 
The revised version 2 operational specification implemented some significant changes and refinements:

1. Incident coding and event coding should occur separately in different coding rounds, not together in the same coding exercise

2. Addition of a preliminary code book of incident codes that were distinct from the event descriptions

Coding pilot $\# 2$ was comprised of three activities. The first activity described the emancipation examples from Rindova et al. (2009) using the common framework for events from the version 2 operational specification. Results from the first activity were previously reported as Table 3 , Table 4, and Table 5 in subsections 2.1.1, 2.1.2, and 2.1.3, respectively, of the literature review (chapter 2). The second activity re-examined the pilot source (i.e., the SpaceX press release previously examined in coding pilot \#1), recoding incidents in NVivo using the version 2 operational specification where incident coding and event coding occur separately, and using NVivo case notes and linked case memos to describe and specify events. The third activity examined a sample chapter from a primary source - chapter 6 of Vance (2015), titled "Mice in space", about the founding of SpaceX - coding incidents using the version 2 operational specification, and using NVivo case nodes and linked case memos to describe and specify events. The lessons learned from coding pilot \#2 were captured in a 9-page coding pilot \#2 document and enfolded into a revised version 3 operational specification.

The revised version 3 operational specification included the following additional content and clarifications: 
1. The data file is an NVivo project that includes the primary sources, additional supporting sources, incident codes assigned to passages of text, case codes for each entrepreneur, event cases with attributes, and memos.

2. There are three rounds of coding: incident coding (step 4, described in section 3.4), event coding (step 5, described in 3.5), and organizational form coding (step 6, described in 3.6).

3. The code book of incident codes was significantly expanded.

4. The NVivo project source file would be stored in online cloud storage for access by both the author and the supervisor.

The version 3 operational specification was the final version, employed in steps 4 , 5, and 6 for coding and analysis of the source material. The Appendix (chapter 8) presents the complete version 3 operational specification in its final form.

The initial NVivo project was configured according to the best practices recommended by Bazeley \& Jackson (2013). The Research Support Services staff at the Carleton University Library provided versions of the source material in a form easily imported into NVivo for analysis and addressed any matters of copyright.

\subsection{Step 4: Incident coding}

An initial coding round of incident coding assigned incident codes to passages of text in the primary sources: Branson (2015), Diamandis \& Kotler (2015), and Vance (2015). Each incident code is an NVivo node organized in a hierarchical structure.

The author completed the incident coding, with frequent review and guidance from the supervisor. 
Section 4.4 of the Results chapter provides a summary of the incident codes assigned.

\subsection{Step 5: Event coding}

A second coding round of event coding assigned incidents to emancipation events. Each event is implemented as an NVivo case node. Each incident may be re-coded to one or more event case nodes. Each event is specified in a linked case node memo following the common framework for describing an event.

Event coding was an iterative process, with frequent dialogue between the author and supervisor, and some additional incident coding to fill in gaps in the event descriptions.

Once the set of events had stabilized in NVivo, the author created an event specification document that concisely summarized each event in a tabular format. This was a significant data reduction from the rich event memos in NVivo, but the concise representation of each event was needed for further analysis. The author and supervisor iterated the event document through approximately eight versions until reaching consensus on the events.

The event tables for each case are presented in section 4.5 of the Results chapter.

\subsection{Step 6: Organizational form coding}

A third coding round of organizational form coding assigned organizational form attributes to each event. Each emancipation event was assigned one or more organizational form codes for the three organizational forms of Moore (2006): (1) hierarchy, (2) market, or (3) ecosystem. There were two possible codes for each 
organizational form indicating the strength of the association - evident, or strongly evident - for a total of six possible organizational form codes.

We developed a set of organizational form coding rules to consistently and repeatably determine whether an organizational form was present in an emancipation event. With three emancipation constructs and three possible organizational forms, as well as the possibility for the organizational form to be either evident or strongly evident, we developed 18 distinct criteria, and identified examples in the data set for ten of the criteria. The criteria and examples are provided in Table 15.

We then scored each organizational form by assigning one point for each strongly evident occurrence, and a half-point for each evidence occurrence. The sums of these scores provided a relative measure of the prominence of the organizational form within a particular subset of events - for example, a particular case, or particular event type.

\subsection{Step 7: Cross-case comparison}

The final step was cross-case analysis of the three cases using techniques recommended by Yin (2014). The analytic strategy was explanation-building to account for similarities and differences between cases.

This chapter has explained the research design and each of the seven steps of the research method used to answer the research question. The next chapter presents the results of applying this method. 
Table 15: Criteria for assigning organizational form codes, with examples

\begin{tabular}{|c|c|c|c|c|}
\hline $\begin{array}{l}\text { Organizational } \\
\text { form code }\end{array}$ & Explanation & $\begin{array}{c}\text { Seeking } \\
\text { autonomy }\end{array}$ & Authoring & $\begin{array}{c}\text { Making } \\
\text { declarations }\end{array}$ \\
\hline Hierarchy & $\begin{array}{l}\text { Hierarchical form is evident in the emancipation event: } \\
\text { - control of production } \\
\text { - ideal relationship is "perfect control" } \\
\text { - focus on tasks and activities } \\
\text { - guided directly by entrepreneur (strong direct control) }\end{array}$ & $\begin{array}{l}\text { Hierarchy is the source of the perceived } \\
\text { constraint or how (in part) the } \\
\text { entrepreneur breaks free of or breaks up } \\
\text { the perceived constraint. } \\
\text { Musk-SA-06: independence from } \\
\text { investors; maintain control as CEO. }\end{array}$ & $\begin{array}{l}\text { Hierarchy is the old status quo or } \\
\text { evident in the new arrangements } \\
\text { supporting change intent. } \\
\text { Musk-A-07: As a private company } \\
\text { under Musk's control, SpaceX can } \\
\text { work towards Musk's ultimate goal. }\end{array}$ & $\begin{array}{l}\text { Hierarchy is evident in the } \\
\text { statement of intent to } \\
\text { create change. } \\
\text { No example. }\end{array}$ \\
\hline $\begin{array}{l}\text { Strong } \\
\text { hierarchy }\end{array}$ & $\begin{array}{l}\text { Hierarchy is strongly evident; central to the event: } \\
\text { • e.g., launching new venture(s) } \\
\text { • moving external capability in-house (in-sourcing) }\end{array}$ & $\begin{array}{l}\text { Hierarchy is central to breaking free or } \\
\text { breaking up. } \\
\text { Musk-SA-04: build rockets in-house to } \\
\text { break free of dependence on suppliers. }\end{array}$ & $\begin{array}{l}\text { Hierarchy is central to the new } \\
\text { arrangements. } \\
\text { Musk-A-03: Launch a new space } \\
\text { company operating like a startup. }\end{array}$ & $\begin{array}{l}\text { Hierarchy is central to the } \\
\text { statement of intent. } \\
\text { Branson-MD-01: intent to } \\
\text { maintain control; no IPO. }\end{array}$ \\
\hline Market & $\begin{array}{l}\text { Market form is evident in the emancipation event: } \\
\text { - facilitate transactions for goods } \\
\text { - ideal relationship is "perfectly transparent transactions" } \\
\text { - focus on goods and services } \\
\text { - guided by market forces (the invisible hand of the } \\
\text { market; supply, demand, price) }\end{array}$ & $\begin{array}{l}\text { Markets and market forces are the source } \\
\text { of the perceived constraint or the means } \\
\text { (in part) of breaking free of or breaking up } \\
\text { the constraint. } \\
\text { No example. }\end{array}$ & $\begin{array}{l}\text { Markets is the old status quo or } \\
\text { evident in the new supporting } \\
\text { change intent. } \\
\text { Musk-A-06: Bid for competitive } \\
\text { contracts with NASA, competing } \\
\text { with traditional suppliers. }\end{array}$ & $\begin{array}{l}\text { Markets are evident in the } \\
\text { statement of intent to } \\
\text { create change. } \\
\text { No example. }\end{array}$ \\
\hline $\begin{array}{l}\text { Strong } \\
\text { market }\end{array}$ & $\begin{array}{l}\text { Market is strongly evident; central to the event: } \\
\bullet \text { e.g., obtaining IP through contracts or licensing } \\
\text { • innovation within supply chains and traditional joint } \\
\text { ventures governed through contracts }\end{array}$ & $\begin{array}{l}\text { Markets are central to breaking free or } \\
\text { breaking up. } \\
\text { No example. }\end{array}$ & $\begin{array}{l}\text { Markets are central to the new } \\
\text { arrangements } \\
\text { Branson-A- } 01 \text { : licensing, supply } \\
\text { chain, and joint ventures. }\end{array}$ & $\begin{array}{l}\text { Markets are central to the } \\
\text { statement of intent. } \\
\text { No example. }\end{array}$ \\
\hline $\begin{array}{l}\text { Business } \\
\text { ecosystem }\end{array}$ & $\begin{array}{l}\text { Ecosystem form is evident in the emancipation event: } \\
\text { - facilitate coordination of innovation in goods and the } \\
\text { activities that produce them } \\
\text { - ideal relationship is "perfect co-evolution of innovation" } \\
\text { - focus on a multitude of contributors (size, diversity) } \\
\text { - guided by community leaders (influence; orchestration) }\end{array}$ & $\begin{array}{l}\text { Business ecosystems are the source of } \\
\text { the perceived constraint or the means of } \\
\text { breaking free of or breaking up the } \\
\text { constraint. } \\
\text { No example. }\end{array}$ & $\begin{array}{l}\text { Business ecosystems are the old } \\
\text { status quo or evident in the new } \\
\text { arrangements supporting change } \\
\text { intent. } \\
\text { Musk-A-01: join the voluntary } \\
\text { community of space enthusiasts. }\end{array}$ & $\begin{array}{l}\text { Business ecosystems are } \\
\text { evident in the statement } \\
\text { of intent to create } \\
\text { change. } \\
\text { Diamandis-MD-02: seek } \\
\text { multitude of contributors. }\end{array}$ \\
\hline $\begin{array}{l}\text { Strong } \\
\text { ecosystem }\end{array}$ & $\begin{array}{l}\text { Ecosystem is strongly evident; central to the event: } \\
\text { - e.g., launching new industry platforms or multi-sided } \\
\text { platforms not owned or controlled by the entrepreneur } \\
\text { • innovation by communities voluntary contributors }\end{array}$ & $\begin{array}{l}\text { Business ecosystems are central to } \\
\text { breaking free or breaking up. } \\
\text { No example. }\end{array}$ & $\begin{array}{l}\text { Business ecosystems are central to } \\
\text { the new arrangements. } \\
\text { Diamandis-A-01: coordinate } \\
\text { innovation through prizes. }\end{array}$ & $\begin{array}{l}\text { Business ecosystems are } \\
\text { central to the statement } \\
\text { of intent. } \\
\text { No example. }\end{array}$ \\
\hline
\end{tabular}




\section{Results}

This chapter presents the results in seven sections - one for each step of the research method explained in the previous chapter.

\subsection{Constructs and frameworks}

The research question posed back in section 1.1 examines how the business ecosystem organizational form features in the emancipatory activities of entrepreneurs. Four constructs required operational specification: organizational form, and the three core elements of the emancipation perspective of entrepreneuring identified by Rindova et al. (2009) - seeking autonomy, authoring, and making declarations.

The operational specification of the organizational form construct is adapted from Moore (2006), previously summarized in Table 9.

The operational specification of the emancipation constructs was developed within the scope of this research. As reported in the summary of the literature review (section 2.4), there were no suitable operational specifications of the emancipation constructs found in the prior literature. Section 3.1 previously explained the development of the version 1 operational specification. The third and final iteration of the operational specification is provided as an appendix to the document (chapter 8).

\subsection{Case selection}

The method for case selection was previously described in section 3.2. The following subsections present the set of candidate entrepreneurs and space ventures, develop and apply criteria to select three case, and briefly introduce each case and its source material. 


\subsubsection{Candidate entrepreneurs and space ventures}

Table 16 is the set of candidate entrepreneurs, space ventures, and notes, sequenced alphabetically by surname of the entrepreneur. Only books by traditional publishers are considered; self-published books are excluded from consideration.

\subsubsection{Applying the selection criteria}

Section 3.2 previously developed to two selection criteria to choose the cases from the list of candidates:

(1) there exists a recent book about the entrepreneur and their space venture, either authored by the entrepreneur or about the entrepreneur, to provide source material for our analysis, and

(2) we preferred some variation with respect to the venture's product and service offerings within the domain of commercial spaceflight.

The first criterion eliminated Eric Anderson and Robert Bigelow due to data availability; neither entrepreneur has authored a book, nor been the subject of a book. As a practical matter, it also eliminated Jeff Bezos; both books written about Bezos, Stone (2013) and Brandt (2011), focus on Amazon.com rather than Blue Origin, and both books are older than the 2015 books about or by Branson, Diamandis, and Musk.

The three remaining candidates were Sir Richard Branson, founder of Virgin Galactic, Peter Diamandis, founder of XPRIZE, and Elon Musk, founder and CEO of SpaceX. Each space venture had very different product or service offerings - space tourism, incentive competitions, and launch services, respectively - also satisfying the second criterion for variation of products and services. 
Table 16: Candidate entrepreneurs and space ventures

\begin{tabular}{|c|c|c|}
\hline Entrepreneur & Space venture(s) & Notes \\
\hline Eric Anderson & $\begin{array}{l}\text { Planetary Resources } \\
\text { https://planetaryresources.com } \\
\text { Space Adventures } \\
\text { http://www.spaceadventures.com }\end{array}$ & $\begin{array}{l}\text { - Co-founder of Planetary Resources (2009), } \\
\text { an asteroid mining company, with Peter Diamandis } \\
\text { - Co-founder and CEO of Space Adventures (1998), } \\
\text { a space tourism company, with Peter Diamandis }\end{array}$ \\
\hline Jeff Bezos & $\begin{array}{l}\text { Blue Origin } \\
\text { https://blueorigin.com }\end{array}$ & $\begin{array}{l}\text { - Founder of Blue Origin (2000), a space tourism, } \\
\text { spaceflight services, and aerospace manufacturing } \\
\text { company } \\
\text { - Best known as founder and CEO of Amazon.com (1994) } \\
\text { - Books about Bezos and Amazon include Stone (2013) } \\
\text { and Brandt (2011) }\end{array}$ \\
\hline $\begin{array}{l}\text { Robert } \\
\text { Bigelow }\end{array}$ & $\begin{array}{l}\text { Bigelow Aerospace } \\
\text { https://bigelowaerospace.com }\end{array}$ & $\begin{array}{l}\text { - Founder of Bigelow Aerospace (1998), a provider of } \\
\text { expandable space habitats for space stations }\end{array}$ \\
\hline $\begin{array}{l}\text { Sir Richard } \\
\text { Branson }\end{array}$ & $\begin{array}{l}\text { Virgin Galactic } \\
\text { https://virgingalactic.com }\end{array}$ & $\begin{array}{l}\text { - Founder of Virgin Galactic (2004), a space tourism } \\
\text { company within the Virgin Group } \\
\text { - Best known as founder of the Virgin Group (1970), } \\
\text { a multinational conglomerate controlling more than } 400 \\
\text { companies including Virgin Records (1971) and Virgin } \\
\text { Atlantic (1984). } \\
\text { - Branson is author or co-author of } 7 \text { books including The } \\
\text { Virgin Way: If it's Not Fun, it's Not Worth Doing (2015) }\end{array}$ \\
\hline $\begin{array}{l}\text { Peter } \\
\text { Diamandis }\end{array}$ & $\begin{array}{l}\text { X-Prize Foundation } \\
\text { https://xprize.org }\end{array}$ & $\begin{array}{l}\text { - Founder of XPRIZE (1995; formerly the XPRIZE } \\
\text { Foundation), a not-for-profit company that organizes } \\
\text { incentive competitions that benefit humanity } \\
\text { - Co-founder of Planetary Resources (2009) and Space } \\
\text { Adventures (1998) with Eric Anderson } \\
\text { - Co-founder and executive chairman of Singularity } \\
\text { University (2009), co-founder and former CEO of Zero } \\
\text { Gravity Corporation (2004), co-founder of International } \\
\text { Space University (ISU; 1987), and co-founder of Students } \\
\text { for the Exploration and Development of Space (SEDS; } \\
\text { 1980) } \\
\text { - Co-author of two books with Steven Kotler, Abundance: } \\
\text { The Future is Better Than You Think (2012), and Bold: } \\
\text { How to Go Big, Achieve Success, and Impact the World } \\
\text { (2015) }\end{array}$ \\
\hline Elon Musk & $\begin{array}{l}\text { SpaceX } \\
\text { https://spacex.com }\end{array}$ & $\begin{array}{l}\text { - Founder and CEO of SpaceX (2002), an aerospace } \\
\text { manufacturer and space transport services company } \\
\text { - Also co-founder and CEO of Tesla (2003), co-founder } \\
\text { and chairman of Solar City (2006), co-founder of Zip2 } \\
\text { (1995), and founder of X.com (1999) which became } \\
\text { PayPal (2001). } \\
\text { - Vance (2015), Elon Musk: Tesla, SpaceX, and the Quest } \\
\text { for a Fantastic Future, is a book about Musk and his } \\
\text { companies }\end{array}$ \\
\hline
\end{tabular}




\subsubsection{Case 1: Sir Richard Branson and Virgin Galactic}

The first of the three cases is Sir Richard Branson, founder of Virgin Galactic.

The primary source material is Branson's most recent book, the revised paperback edition of The Virgin Way: If it's not Fun, it's not Worth Doing (Branson, 2015).

Born in London, UK, in 1950, Branson became an entrepreneur at an early age starting a magazine, Student, and founding mail-order record business after dropping out of high school (Forbes, 2017). Branson attributes his dyslexia and borderline Attention Deficit Disorder, in part, for the misfit with traditional schooling (Branson, 2015, p. 4). Branson founded Virgin Records in 1972, which became one of the biggest record companies in the world (Diamandis \& Kotler, 2015, p. 124) and the first of over 500 companies that he founded. The sale of Virgin Records provided Branson with $\$ 800 \mathrm{M}$ which he used to support his nascent Virgin Atlantic airline (Diamandis \& Kotler, 2015, p. 125). In 2004, Branson entered the commercial spaceflight business with a "deal under which a new space tourism company, Virgin Galactic, would license the technology behind Spaceship One_-funded by Microsoft co-founder Paul Allen and designed by Burt Rutan — to take paying passengers into suborbital space” (Klotz, 2013).

\subsubsection{Case 2: Peter Diamandis and XPRIZE}

The second of the three cases is Peter Diamandis, founder and executive chairman

of XPRIZE. The primary source material is Diamandis' second and most recent book, the first edition of Bold: How to Go Big, Achieve Success, and Impact the World (Diamandis \& Kotler, 2015).

According to his own personal website (https://diamandis.com), "Dr. Peter H. 
Diamandis is an international pioneer in the fields of innovation, incentive competitions and commercial space. In 2014 he was named one of 'The World's 50 Greatest Leaders' by Fortune Magazine.” Born in 1961, Diamandis “was a standout pre-med student as well, winning awards for his undergraduate life sciences research and admission to Harvard Medical School. But with just a year left to graduate he darted back to M.I.T. to get a degree in aeronautics and astronautics, then returned to Harvard to finish his M.D." (Caulfield, 2012). In 1995, Diamandis founded the XPRIZE Foundation, best known for the $\$ 10$ million Ansari XPRIZE for private spaceflight (awarded in 2004), and the Google Lunar X-Prize for landing a privately-funded robot on the moon (ongoing). Diamandis is Co-Founder and Co-Chairman of Planetary Resources, a company designing spacecraft to enable the detection and prospecting of asteroid for precious materials. He is also the Co-Founder of Space Adventures and Zero-Gravity Corporation.

\subsubsection{Case 3: Elon Musk and SpaceX}

The third of the three cases is Elon Musk, founder and CEO of SpaceX. The primary source material is Ashlee Vance's business biography, Elon Musk: Tesla, SpaceX, and the Quest for a Fantastic Future (Vance, 2015). According to the author, this is the first (and currently the only) book written with Musk's cooperation: "Musk granted me access to the executives at his companies, his friends, and his family. He would meet me for dinner once a month for as long as it took" (Vance, 2015, p. 4). Nonetheless, it was an independent and critical effort; Vance claims that Musk neither approved nor reviewed drafts of the book prior to publication (p. 2). 
Born in South Africa in 1971, Musk won $\$ 500$ at the age of 12 for a video game he created and published in PC and Office Technology in what was the start of a precocious career. Musk left South Africa at the age of 17 to study at Queen's University in Canada - as a stepping stone to emigration to the United States. In 1992, Musk transferred to the Ivy League University of Pennsylvania where he studied economics and physics. Musk moved to California in 1995 to begin a Ph.D. at Stanford, but soon quit to pursue his entrepreneurial aspirations (Belfiore, 2007, p. 166). Musk's first company was Zip2, an internet-based, search-able, company directory (Vance, 2015, p. 61) which was acquired by Compaq in 1999 leaving Musk with \$22M (Vance, 2015, p. 14). In 1999, Musk created X.com, which evolved into PayPal, and from which he was ousted as CEO in October 2000 (Vance, 2015, p. 88). When PayPal was acquired by eBay in 2002, Musk received $\$ 180 \mathrm{M}$ after taxes (Vance, 2015, p. 89), which became the staring capital for both SpaceX (2002) and Tesla Motors (2003).

\subsection{Coding pilots}

The operational specification developed in step 1, including the coding rules, the preliminary list of incident codes, the common framework for describing an event, and the tool selection, were trialled with small test samples of source material in a series of coding pilot exercises following the method previously explained in section 3.3. The pilot exercises were intended to refine and validate the operational specification. The learning from these pilot exercises was enfolded into the later steps of the method previously explained in chapter 3 , and the version 3 operational specification provided as an appendix to this document (chapter 8).

\section{Copyright (C) 2018 Ewan Reid}




\subsection{Incidents}

The method for incident coding - the fourth step of the research method and the first of the three rounds of coding - was previously explained in section 3.4. Recall that an incident is a coded passage of text from a primary source (Abbot, 1984; Van de Ven, 2007). The qualitative datum for an incident is a referenced passage of text, formally specified as a bracketed string of words about an occurrence of emancipation, excerpted from a source, with a reference to the source and location of the words within the source. The set of coded incidents is an input to step 5 of the method where the incidents are re-

coded to a smaller set of emancipation events. The use of NVivo qualitative data analysis software simplified and streamlined incident coding.

A total of 655 incident codes were assigned to source material. Table 17 reports the distribution of incident codes. 
Table 17: Incident Coding Summary

\begin{tabular}{|c|c|c|c|c|}
\hline Category I & Sub-category I & Sub-category II & Sub-category III & Count \\
\hline \multirow[t]{8}{*}{ Emancipation } & \multirow[t]{2}{*}{ Authoring } & New arrangement & & 91 \\
\hline & & Old status quo & & 76 \\
\hline & \multirow[t]{4}{*}{ Making declarations } & Contestation & & 37 \\
\hline & & Forms & & 6 \\
\hline & & $\begin{array}{l}\text { Overcoming } \\
\text { contestation }\end{array}$ & & 39 \\
\hline & & $\begin{array}{l}\text { Statement of intent to } \\
\text { create change }\end{array}$ & & 56 \\
\hline & \multirow[t]{2}{*}{ Seeking autonomy } & Break free or break up & & 68 \\
\hline & & Perceived constraint & & 68 \\
\hline \multirow[t]{7}{*}{ Actors } & \multirow[t]{3}{*}{ Companies } & Blue Origin & & 1 \\
\hline & & Google & & 3 \\
\hline & & $\begin{array}{l}\text { Virgin Group } \\
\text { Companies }\end{array}$ & & 16 \\
\hline & People & Bezos & & 8 \\
\hline & Russians & & & 9 \\
\hline & \multirow[t]{2}{*}{ Space agencies } & ESA & & 1 \\
\hline & & NASA & & 6 \\
\hline \multirow[t]{7}{*}{ Ad hoc codes } & Dyslexia & & & 4 \\
\hline & $\begin{array}{l}\text { Exponential } \\
\text { entrepreneur }\end{array}$ & & & 9 \\
\hline & Fun & & & 26 \\
\hline & Mars & & & 3 \\
\hline & Moon & & & 1 \\
\hline & Praise by others & & & 3 \\
\hline & The Virgin way & & & 17 \\
\hline \multirow[t]{3}{*}{ Funding } & Contracts from NASA & & & 9 \\
\hline & Crowdfunding & & & 1 \\
\hline & Private funding & & & 4 \\
\hline \multirow[t]{12}{*}{ Systems } & ISS & & & 11 \\
\hline & NASA Systems & Apollo & & 5 \\
\hline & \multirow[t]{3}{*}{ Russian Systems } & ICMBs & & 3 \\
\hline & & Soyuz capsule & & 1 \\
\hline & & Soyuz rockets & & 1 \\
\hline & \multirow[t]{6}{*}{ SpaceX systems } & Rockets & Falcon 1 & 18 \\
\hline & & & Falcon 5 & 3 \\
\hline & & & Falcon 9 & 18 \\
\hline & & & Falcon Heavy & 4 \\
\hline & & Spacecraft & Dragon & 19 \\
\hline & & & Dragon 2 (crewed) & 8 \\
\hline & X-Prize systems & GLXP & & 2 \\
\hline
\end{tabular}




\subsection{Events}

The method for event coding - the fifth step of the research method and the second of the three rounds of coding - was previously explained in section 3.5. Recall that events are constructs; as constructs, they are not directly observable, but rather are indicated by incidents in the source material (Abbot, 1984; Van de Ven, 2007). The events in this research are occurrences of the three core elements of the emancipation perspective of entrepreneuring (Rindova et al. 2009): seeking autonomy (SA), authoring (A), and making declarations (MD), reviewed in section 2.1.

Table 18 is a cross-tabulation of event counts by entrepreneur and event type.

Table 18: Counts of events, by entrepreneur and event type

\begin{tabular}{lcccc}
\hline Entrepreneur & $\begin{array}{c}\text { Seeking autonomy } \\
\text { (SA) }\end{array}$ & $\begin{array}{c}\text { Authoring } \\
\text { (A) }\end{array}$ & $\begin{array}{c}\text { Making declarations } \\
\text { (MD) }\end{array}$ & Totals \\
\hline Branson & 2 & 3 & 2 & 7 \\
\hline Diamandis & 2 & 3 & 3 & 8 \\
\hline Musk & 6 & 7 & 4 & 17 \\
\hline Totals & 10 & 13 & 9 & 32 \\
\hline
\end{tabular}

There were 32 emancipation events in total. Approximately half of the events were associated with Musk ( $\mathrm{n}=17)$, one quarter with Diamandis $(\mathrm{n}=8)$, and one quarter with Branson $(n=7)$. This difference is likely explained by the nature of the source material: Vance (2015), the source for Musk, has more to say about Musk's space venture than either Diamandis \& Kotler (2015) or Branson (2015), the sources for Diamandis and Branson respectively, have to say about space ventures. The events are of all three event types, with approximately $40 \%$ authoring $(n=13), 30 \%$ seeking autonomy $(n=10)$, and 
$30 \%$ making declarations $(\mathrm{n}=9)$. These proportions also make sense, because seeking to break free of a perceived constraint may motivate many different actions - both of establishing new arrangements (authoring) and of stating intent to make change (making declarations).

This event data set of 32 observations, in three cases, with three event categories, is amenable to the qualitative data analysis techniques of Miles \& Huberman (1994) and Yin (2014), described in section 3.6 and with results reported in section 4.6, and the cross-case analysis techniques of Yin (2014), described in section 3.7 and with results reported in section 4.7. According to the guidelines of Van de Ven (2007) and Poole et al. (2000), we argue that a set of 32 observations is sufficiently large for qualitative and cross-case analysis, but not so large as to overwhelm these small sample techniques.

\subsubsection{Branson}

There are seven emancipation events in total for Sir Richard Branson. Table 19 summarizes the two seeking autonomy events. Page numbers in this subsection refer to Branson (2015), The Virgin Way, unless otherwise noted. 
Table 19: Branson: seeking autonomy events

\begin{tabular}{|c|c|c|}
\hline $\begin{array}{l}\text { Seeking } \\
\text { autonomy } \\
\text { event }\end{array}$ & Perceived constraint & Breaking free of or breaking up the perceived constraint \\
\hline \multirow{3}{*}{$\begin{array}{l}\text { 01-Improve } \\
\text { lives }\end{array}$} & \multirow{3}{*}{$\begin{array}{l}\text { Most companies } \\
\text { address low-impact } \\
\text { problems and make } \\
\text { decisions based on } \\
\text { expected profits and } \\
\text { "working to improve } \\
\text { shareholder value" }\end{array}$} & Launch and lead companies that improve lives. \\
\hline & & $\begin{array}{l}\text { Branson writes: "If you aren't making a positive difference to other } \\
\text { people's lives, then you shouldn't be in business. Companies have a } \\
\text { responsibility to make a difference in the world, for their staff, their } \\
\text { customers-everyone. The amazing part is that doing good is also } \\
\text { good for business" (pp. 375-376). }\end{array}$ \\
\hline & & $\begin{array}{l}\text { "Companies can realize this potential by looking for ways to do things } \\
\text { differently, and by putting our people and the planet right up there } \\
\text { alongside growth, and profit as our raison d'etre" (p. 273). }\end{array}$ \\
\hline \multirow[t]{3}{*}{$\begin{array}{l}\text { 02-Escape } \\
\text { boredom: } \\
\text { "If it's not fun, } \\
\text { it's not worth } \\
\text { doing" }\end{array}$} & \multirow[t]{3}{*}{$\begin{array}{l}\text { Most projects and } \\
\text { business opportunities } \\
\text { are unexciting, boring. }\end{array}$} & $\begin{array}{l}\text { "I have always had one paramount philosophy: if a new project or } \\
\text { business opportunity doesn't excite me and get my entrepreneurial } \\
\text { and innovative juices flowing, if it's not something with which I sense I } \\
\text { can make a difference while having a lot of seriously creative fun, then } \\
\text { l'd far rather pass on it and move right along to something else that } \\
\text { does excite me" (p. 1). }\end{array}$ \\
\hline & & $\begin{array}{l}\text { "[lf an idea doesn't sound fun], l'd far rather pass on it and move right } \\
\text { along to something else that does excite me" (p. } 1 .\end{array}$ \\
\hline & & $\begin{array}{l}\text { Fun is embedded in the Virgin brand and culture: "It's about having } \\
\text { fun with a capital F while we're doing it. Leading 'the Virgin way' often } \\
\text { has quite unpredictable consequences and takes us to places where } \\
\text { other 'more sensible' operations might fear to tread" (p. 6). }\end{array}$ \\
\hline
\end{tabular}

The first event (Branson-SA-1) was about improving lives. Branson feels

dissatisfied with the limited impact made by nearly all businesses, and strives to break

free of this constraint with his own high-impact businesses. This was a recurring theme

throughout Branson (2015).

The second event (Branson-SA-2) was about escaping from boredom and having

fun. Diamandis describes Branson as a "fun junkie" (Diamandis \& Kotler, 2015, p. 125),

and argues that this helps Branson in two ways - first, by being passionate about

everything that he does, and second, because what he does is likely to be fun others also.

"If it's not fun, it's not worth doing" is the subtitle of Branson's book.

Table 20 summarizes the three authoring events for Branson. 
Table 20: Branson: authoring events

\begin{tabular}{|c|c|c|}
\hline $\begin{array}{l}\text { Authoring } \\
\text { event }\end{array}$ & $\begin{array}{l}\text { Old status quo } \\
\text { to be changed }\end{array}$ & New arrangement supporting change-creating intent \\
\hline \multirow[t]{5}{*}{$\begin{array}{l}\text { 01-Virgin } \\
\text { Galactic }\end{array}$} & \multirow{2}{*}{$\begin{array}{l}\text { Space tourism is } \\
\text { available only to } \\
\text { the super-rich. }\end{array}$} & $\begin{array}{l}\text { Branson founded Virgin Galactic in } 2004 \text {. From the website: "Only } 559 \text { people } \\
\text { have been to space. Virgin Galactic is opening space to the rest of us." }\end{array}$ \\
\hline & & "When aviation legend Burt Rutan won the $\$ 10$ million Ansari XPRIZE with \\
\hline & \multirow[t]{3}{*}{$\begin{array}{l}\text { The Russian } \\
\text { Federation offers } \\
\text { trips to low-earth } \\
\text { orbit (LEO) } \\
\text { priced at } \\
\sim \text { US } \$ 50 \mathrm{~m} \text {. }\end{array}$} & $\begin{array}{l}\text { SpaceShipOne, Sir Richard Branson swooped in to license the winning } \\
\text { technology, committing a quarter of a billion dollars to develop Virgin Galactic's } \\
\text { SpaceShipTwo--the commercial follow-on to SpaceShipOne" (Diamandis \& } \\
\text { Kotler, 2015, p. 97). SpaceShipOne launched from a custom carrier aircraft } \\
\text { called White Knight One. }\end{array}$ \\
\hline & & $\begin{array}{l}\text { Several companies were involved: Mojave Aerospace Ventures owned the } \\
\text { intellectual property for SpaceShipOne, Scaled Composites manufactured } \\
\text { SpaceShipOne and White Knight One, and would build the prototypes of } \\
\text { SpaceShipTwo and White Knight Two, and The Spaceship Company (founded in } \\
2005 \text { by Branson and Rutan, jointly owned by Virgin Galactic and Scaled } \\
\text { Composites) would build the production units of SpaceshipTwo and } \\
\text { WhiteKnightTwo. }\end{array}$ \\
\hline & & $\begin{array}{l}\text { Virgin Galactic provides a "unique opportunity to travel into space and } \\
\text { experience weightlessness while looking down on our planet from an altitude a } \\
\text { dozen times higher than commercial flight levels" (p. 371). }\end{array}$ \\
\hline \multirow[t]{3}{*}{$\begin{array}{l}\text { 02-The } \\
\text { Virgin Way }\end{array}$} & \multirow{3}{*}{$\begin{array}{l}\text { Traditional } \\
\text { corporate } \\
\text { culture, mission } \\
\text { statements, and } \\
\text { regimented work } \\
\text { environments. }\end{array}$} & $\begin{array}{l}\text { The Virgin Way is the corporate culture at Virgin Group. Branson writes: } \\
\text { "I frequently get way too much individual credit for the success of these } \\
\text { companies when it is usually a case of the Virgin Way giving our people the } \\
\text { freedom to express themselves by letting their imaginations take flight." (p. 379). }\end{array}$ \\
\hline & & $\begin{array}{l}\text { "The Virgin Way takes us to places where other 'more sensible' operations might } \\
\text { fear to tread" (p. 6). It is "listening, learning, laughing, and leading" (p. 379). }\end{array}$ \\
\hline & & $\begin{array}{l}\text { "Managing our businesses is all about maintaining and promoting that almost } \\
\text { childish curiosity level in our people to ensure they are never accepting of the } \\
\text { status quo and always looking for ways to improve upon it" (p. 129) }\end{array}$ \\
\hline \multirow{3}{*}{$\begin{array}{l}\text { 03- } \\
\text { Branson's } \\
\text { leadership } \\
\text { style }\end{array}$} & \multirow[t]{3}{*}{$\begin{array}{l}\text { Authoritarian } \\
\text { leadership that } \\
\text { punishes failure. }\end{array}$} & $\begin{array}{l}\text { Branson summarizes his leadership style as "Having a great time while building a } \\
\text { highly diversified global business with an extended family of simply wonderful } \\
\text { people" (p. 9). }\end{array}$ \\
\hline & & $\begin{array}{l}\text { Branson's advice for leaders includes follow your dreams, make a positive } \\
\text { difference and do some good, believe in your ideas, have fun and look after your } \\
\text { team, don't give up, listen and take lots of notes, delegate and spend time with } \\
\text { your family, and go out into the world (pp. 375-379). Branson values the } \\
\text { "courage to own up to mistakes" (p. 58), "simplicity in communications" (p. 80), } \\
\text { and "take risks, embrace failure" (p. 276). }\end{array}$ \\
\hline & & $\begin{array}{l}\text { Branson learns through direct experience: "I have spent the balance of my life } \\
\text { with a thirst for learning about new things, businesses, people and cultures... My } \\
\text { learning process has involved experiencing all these things first-hand as } \\
\text { opposed to reading about them in books" (p. 4). "The old way was particularly } \\
\text { challenging for someone like me with dyslexia and borderline ADD - attention } \\
\text { deficit disorder" (p. 4). }\end{array}$ \\
\hline
\end{tabular}

Table 21 summarizes the two making declarations events for Branson. 
Table 21: Branson: making declarations events

\begin{tabular}{|c|c|c|c|c|}
\hline $\begin{array}{l}\text { Making } \\
\text { declarations } \\
\text { event }\end{array}$ & $\begin{array}{l}\text { Statement of intent to } \\
\text { create change }\end{array}$ & $\begin{array}{l}\text { Forms of the } \\
\text { discursive or } \\
\text { rhetorical acts }\end{array}$ & $\begin{array}{l}\text { Contestations } \\
\text { from others }\end{array}$ & $\begin{array}{l}\text { Overcoming } \\
\text { contestations }\end{array}$ \\
\hline $\begin{array}{l}\text { 01-Maintain } \\
\text { full control of } \\
\text { company }\end{array}$ & $\begin{array}{l}\text { "Let's face it: countries go to } \\
\text { war to protect their freedom } \\
\text { and independence" ( } \mathrm{p} \text {. } \\
\text { 165). The way to drive a } \\
\text { company's direction is to } \\
\text { maintain freedom and } \\
\text { independence. }\end{array}$ & $\begin{array}{l}\text { Books, } \\
\text { presentations, } \\
\text { and interviews. } \\
\text { Action to keep } \\
\text { Virgin Galactic } \\
\text { and other } \\
\text { companies in the } \\
\text { Virgin Group } \\
\text { privately-held. }\end{array}$ & $\begin{array}{l}\text { "Sure, Richard. I'm } \\
\text { not saying I want to } \\
\text { do it, but if I were to } \\
\text { go the IPO route I'd } \\
\text { only sell a minority } \\
\text { stake so I'd have the } \\
\text { best of both worlds- } \\
\text { we'd raise some } \\
\text { cash and l'd still be } \\
\text { running the } \\
\text { company-right?" (p. } \\
\text { 165). }\end{array}$ & $\begin{array}{l}\text { "Wrong! Trust me, I've } \\
\text { been there. While on } \\
\text { paper you may still be } \\
\text { running the company, I } \\
\text { can assure you from } \\
\text { personal experience that } \\
\text { the company you're } \\
\text { running and your freedom } \\
\text { to run it the way you're } \\
\text { accustomed to doing, are } \\
\text { never going to be the } \\
\text { same after you've gone } \\
\text { public" (p. 165). }\end{array}$ \\
\hline $\begin{array}{l}02-T h e \text { Virgin } \\
\text { Way }\end{array}$ & $\begin{array}{l}\text { The Virgin Way declares } \\
\text { the shared expectations of } \\
\text { how things are done } \\
\text { differently at Virgin. } \\
\text { "When someone who has } \\
\text { just joined us from outside } \\
\text { comes out of their first, } \\
\text { usually highly informal, } \\
\text { strategy or product meeting } \\
\text { and says, 'Wow, you folks } \\
\text { certainly do things } \\
\text { differently, don't you?' the } \\
\text { response is often, 'Yup, } \\
\text { that's the Virgin way', } \\
\text { usually said with a smile } \\
\text { and a knowing wink" (p. 5). }\end{array}$ & $\begin{array}{l}\text { Books, } \\
\text { presentations, } \\
\text { and interviews. } \\
\text { Embedded in } \\
\text { everyday } \\
\text { discourse and } \\
\text { corporate } \\
\text { culture. }\end{array}$ & & \\
\hline
\end{tabular}

\subsubsection{Diamandis}

There are eight emancipation events in total for Peter Diamandis. Table 22

summarizes the two seeking autonomy events. Page numbers in this subsection refer to

Diamandis \& Kotler (2015), Bold, unless otherwise noted. 
Table 22: Diamandis: seeking autonomy events

\begin{tabular}{lll}
\hline $\begin{array}{l}\text { Seeking } \\
\text { autonomy } \\
\text { event }\end{array}$ & Perceived constraint & $\begin{array}{l}\text { Breaking free of or breaking up the perceived } \\
\text { constraint }\end{array}$
\end{tabular}

01-NASA "I was only eight years old when Apollo 11 cannot get $m e$ landed on the moon, and i decided then

Co-founded Students for the Exploration and to space and there that going into space was what I wanted to do with my life. I was in my early twenties when I realized NASA was never going to get me there. Constrained by government spending and frightened by the risk of failure, the space agency had become a military-industrial jobs program unlikely to return to the Moon or push onward to Mars" (p. 96). Development of Space (SEDS) in 1980 while an undergraduate to link people interested in space. Started private space ventures without government help.

Explored novel approaches to motivate innovation in spaceflight from people and private companies: "Have a vision for tomorrow, pull yourself toward it. I wanted a future that included private commercial space flight, so I launched the XPRIZE" (p. 109).

02-More than Over-reliance on monetary rewards has money limited progress on big problems.

Motivate with intrinsic rewards: "Autonomy is the desire to steer our own ship. Mastery is the desire "[Money as an extrinsic reward] lowers motivation, hinders creativity, and decreases performance. What's more, this isn't the only issue with money as a motivator. Money, it now appears, is only an effective motivator until our basic biological needs are met, with a little left over for discretionary spending" (p. 78).

"Once we pay people enough so that meeting basic needs is no longer a to steer it well. And purpose is the need for the journey to mean something. These three intrinsic rewards are the very motivators that motivate us most" (p. 79).

"The science shows that the secret to high performance isn't our biological drive (our survival needs) or our reward-and-punishment drive, but our third drive-our deep-seated desire to direct our own lives, to extend and expand our abilities, and to fill our life with purpose" (p. 79).

constant cause for concern, extrinsic rewards lose their effectiveness" (p. 79).

Table 23 summarizes the three authoring events for Diamandis. 
Table 23: Diamandis: authoring events

\begin{tabular}{|c|c|c|}
\hline $\begin{array}{l}\text { Authoring } \\
\text { event }\end{array}$ & Old status quo to be changed & New arrangement supporting change-creating intent \\
\hline \multirow[t]{4}{*}{$\begin{array}{l}\text { 01-Incentive } \\
\text { prizes to solve } \\
\text { global } \\
\text { challenges }\end{array}$} & \multirow[t]{2}{*}{$\begin{array}{l}\text { "Before the Ansari XPRIZE, few } \\
\text { investors seriously considered the } \\
\text { market for commercial space flight; } \\
\text { it was assumed to be the sole } \\
\text { province of governments" (p. 246); } \\
\text { market failures hindered } \\
\text { investment; entrenched incumbents } \\
\text { limited progress. }\end{array}$} & $\begin{array}{l}\text { Founded the } X \text { PRIZE Foundation in in } 1995 \text {, and } \\
\text { launched the first X Prize competition in 1996: a US } \$ 10 M \\
\text { prize for the first non-government organization to launch a } \\
\text { reusable manned spacecraft into space twice within two } \\
\text { weeks. The prize, later renamed the Ansari } X \text { Prize after a } \\
\text { major donor, was won in } 2004 \text { using the experimental } \\
\text { spaceplane SpaceShipOne. }\end{array}$ \\
\hline & & Other XPRIZE space competitions include the Northrop \\
\hline & \multirow[t]{2}{*}{$\begin{array}{l}\text { Similar obstacles impede other } \\
\text { global challenges. }\end{array}$} & $\begin{array}{l}\text { Grumman Lunar Lander XCHALLENGE (2006; awarded in } \\
\text { 2009), and the Google Lunar XPRIZE (2007; ongoing). }\end{array}$ \\
\hline & & $\begin{array}{l}\text { Incentive prizes spur innovation beyond value of the prize: } \\
\text { "For the exponential entrepreneur, the incentive prize is a } \\
\text { mechanism for solving a personal challenge or a global } \\
\text { injustice or bringing a new technology into existence" (p. } \\
244 \text { ). Donors can motivate "radical breakthroughs for the } \\
\text { benefit of humanity." }\end{array}$ \\
\hline \multirow[t]{3}{*}{$\begin{array}{l}\text { 02-Launch and } \\
\text { grow space } \\
\text { companies }\end{array}$} & \multirow[t]{3}{*}{$\begin{array}{l}\text { Progress in space was moving too } \\
\text { slowly (p. 97). Government space } \\
\text { agencies were unlikely to return to } \\
\text { the Moon or push onward to Mars } \\
\text { (p. 96). }\end{array}$} & $\begin{array}{l}\text { "If were going to boldly go, it was going to have to be } \\
\text { without the help of government. Thus I devoted the next } \\
\text { thirty years to starting private ventures that I thought would } \\
\text { open the space frontier" (p. 96): }\end{array}$ \\
\hline & & $\begin{array}{ll}\text { - } & \text { International Space University (1987) } \\
\text { - } & \text { Zero Gravity Corporation (1994) } \\
\text { - } & \text { Space Adventures Limited (1988) } \\
\text { - } & \text { Blast Off Corporation (2000-2001) } \\
\text { - } & \text { Planetary Resources (2012) }\end{array}$ \\
\hline & & $\begin{array}{l}\text { Regarding asteroid mining: "To open up space ... we } \\
\text { needed to exploit the same economic engine that had } \\
\text { opened every previous frontier: the search for resources" } \\
\text { (p. 97). "To pull off such a massive moonshot, we're going } \\
\text { to need help, a lot of help. And thus our first challenge-- } \\
\text { convincing anyone our dream was doable" (p. 98). }\end{array}$ \\
\hline \multirow{4}{*}{$\begin{array}{l}\text { 03-Enable } \\
\text { others to solve } \\
\text { big problems }\end{array}$} & \multirow{4}{*}{$\begin{array}{l}\text { "Thousands of years ago, it was } \\
\text { only kings, pharaohs, and emperors } \\
\text { who had the ability to solve large- } \\
\text { scale problems. Hundreds of years } \\
\text { ago, this power expanded to the } \\
\text { industrialists who built our } \\
\text { transportation systems and financial } \\
\text { institutions" (p. xii). }\end{array}$} & $\begin{array}{l}\text { Co-founded Singularity University in } 2008 \text { to teach } \\
\text { exponential thinking and how to solve big problems. }\end{array}$ \\
\hline & & $\begin{array}{l}\text { Codified knowledge through two books, Abundance (2012) } \\
\text { and Bold (2015), and a TED talk (2012): }\end{array}$ \\
\hline & & $\begin{array}{l}\text { "Today, the ability to solve such problems has been } \\
\text { thoroughly democratized. Right now, and for the first time } \\
\text { ever, a passionate and committed individual has access to } \\
\text { the technology, minds, and capital required to take on any } \\
\text { challenge" (p. xii). }\end{array}$ \\
\hline & & $\begin{array}{l}\text { Exponential entrepreneurs can "make their boldest } \\
\text { dreams come true" (p. xiii) by getting help from "today's } \\
\text { hyper-connected crowd" (p. xiii) in four ways: } \\
\text { (1) crowdsourcing, (2) crowdfunding, (3) building } \\
\text { communities, and (4) incentive competitions. }\end{array}$ \\
\hline
\end{tabular}

Table 24 summarizes the three making declarations events for Diamandis. 
Table 24: Diamandis: making declarations events

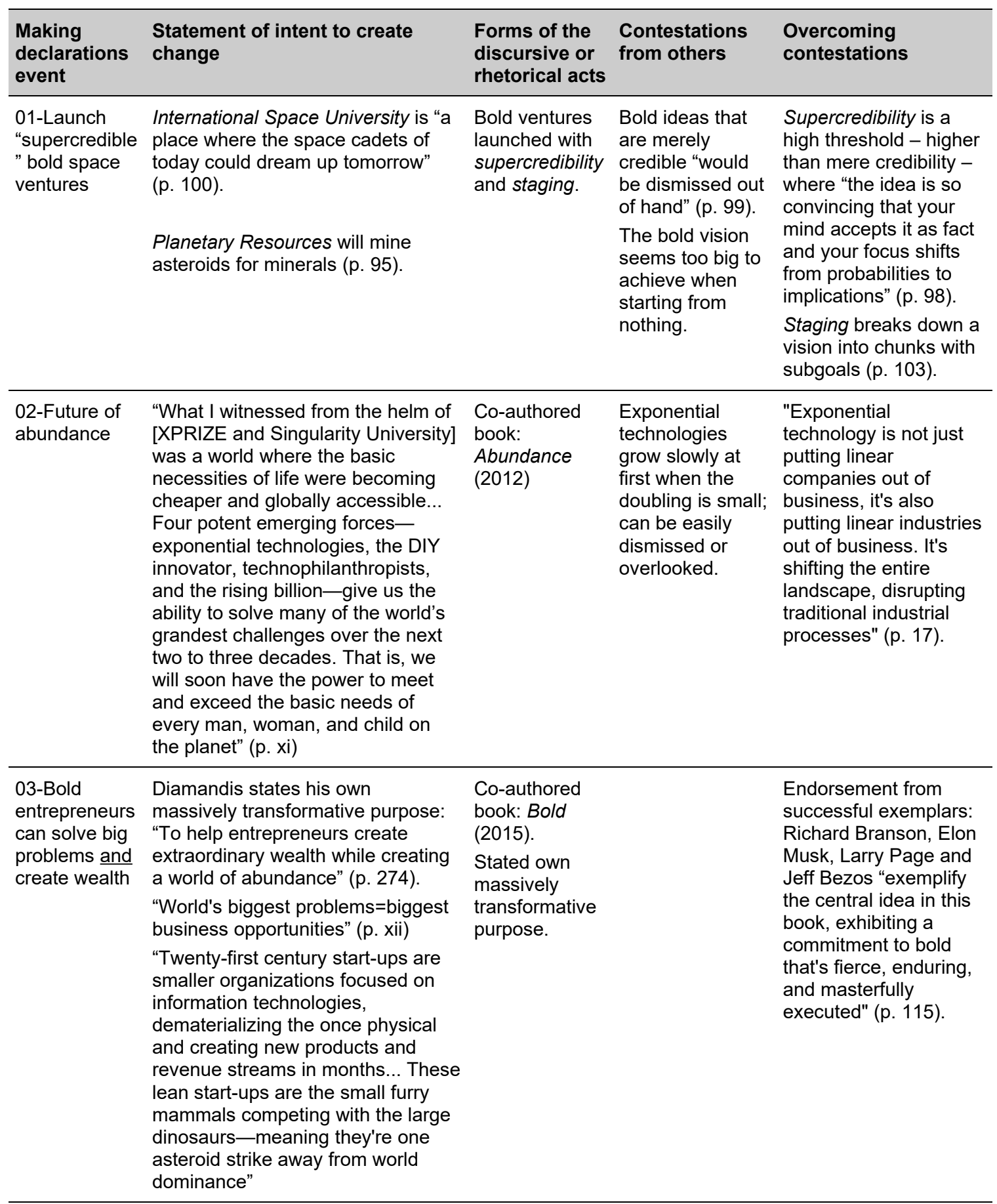




\subsubsection{Musk}

There are seventeen emancipation events in total for Elon Musk and SpaceX.

Table 25 (part 1 of 2) and Table 26 (part 2 of 2) summarize the six seeking autonomy

events. Page numbers in this subsection refer to Vance (2015) unless otherwise noted.

Table 25: Musk: seeking autonomy events (part 1 of 2)

\begin{tabular}{|c|c|c|}
\hline $\begin{array}{l}\text { Seeking } \\
\text { autonomy } \\
\text { event }\end{array}$ & Perceived constraint & $\begin{array}{l}\text { Breaking free of or breaking up the perceived } \\
\text { constraint }\end{array}$ \\
\hline \multirow[t]{2}{*}{$\begin{array}{l}\text { 01-Space has } \\
\text { become boring }\end{array}$} & \multirow{2}{*}{$\begin{array}{l}\text { Space has become boring; no longer } \\
\text { exciting. People "had grown cynical } \\
\text { about anything novel happening in } \\
\text { space again" (p. 103). }\end{array}$} & $\begin{array}{l}\text { "Musk would inspire people to think about exploring } \\
\text { space again by making it cheaper" (p. 108). }\end{array}$ \\
\hline & & $\begin{array}{l}\text { "He wanted to inspire the masses and reinvigorate their } \\
\text { passion for science, conquest, and the promise of } \\
\text { technology" (p. 101). }\end{array}$ \\
\hline \multirow[t]{2}{*}{$\begin{array}{l}02-\text { Do } \\
\text { something that } \\
\text { matters }\end{array}$} & $\begin{array}{l}\text { The Internet runs on advertising. Too } \\
\text { much top talent is wasted working on } \\
\text { ways to sell more ads. }\end{array}$ & $\begin{array}{l}\text { "Where Mark Zuckerberg wants to help you share baby } \\
\text { photos, Musk wants to ... well ... save the human race } \\
\text { from self-imposed or accidental annihilation" (p. 17). }\end{array}$ \\
\hline & $\begin{array}{l}\text { Musk states: "There are probably too } \\
\text { many smart people pursuing Internet } \\
\text { stuff, finance, and law" (p. 9). }\end{array}$ & $\begin{array}{l}\text { "[Musk's] empathy is unique. He seems to feel for the } \\
\text { human species as a whole without always wanting to } \\
\text { consider the wants and needs of individuals" (p. 363). }\end{array}$ \\
\hline \multirow[t]{4}{*}{$\begin{array}{l}\text { 03-CEO in } \\
\text { control of own } \\
\text { company }\end{array}$} & \multirow{4}{*}{$\begin{array}{l}\text { Musk "wanted to be CEO" (p. 67) but } \\
\text { "at both Zip2 and PayPal, the } \\
\text { companies' boards came to the } \\
\text { conclusion that Musk was not yet CEO } \\
\text { material" (p. 91). Both "had been } \\
\text { ripped away from Musk and given to } \\
\text { someone else to run" (p. 97). } \\
\text { Successful technology companies are } \\
\text { expected to "go public" to raise capital } \\
\text { and provide an exit for early investors. }\end{array}$} & $\begin{array}{l}\text { Musk founded SpaceX with } \$ 100 \mathrm{M} \text { of his own money } \\
\text { from the acquisition of PayPal by eBay in } 2002 \text {. } \\
\text { Launching, growing, and exiting two previous } \\
\text { companies, Zip2 and X.com, provided credibility, and } \\
\text { investing his own money provided autonomy. }\end{array}$ \\
\hline & & $\begin{array}{l}\text { "With such a massive up-front investment, no one would } \\
\text { be able to wrestle control of SpaceX away from Musk as }\end{array}$ \\
\hline & & they had done at Zip2 and PayPal” (p. 116). \\
\hline & & $\begin{array}{l}\text { SpaceX remains privately held. Musk writes in email to } \\
\text { staff: "Creating the technology needed to establish life } \\
\text { on Mars is and always has been the fundamental goal } \\
\text { of SpaceX. If being a public company diminishes that } \\
\text { likelihood, then we should not do so until Mars is } \\
\text { secure" (p. 260) }\end{array}$ \\
\hline \multirow{2}{*}{$\begin{array}{l}\text { 04-Must use } \\
\text { Russian } \\
\text { launch } \\
\text { vehicles }\end{array}$} & $\begin{array}{l}\text { Russia is the sole supplier of launch } \\
\text { vehicles for space missions.. }\end{array}$ & \multirow{2}{*}{$\begin{array}{l}\text { Musk built the Falcon rocket for small payload missions. } \\
\text { "Musk would inspire people ... by making it cheaper to } \\
\text { explore space" (p. 108). }\end{array}$} \\
\hline & $\begin{array}{l}\text { "The Russians were the only ones } \\
\text { with rockets that could possibly fit } \\
\text { within Musk's budget" (p. 103). }\end{array}$ & \\
\hline
\end{tabular}


Table 26: Musk: seeking autonomy events (part 2 of 2)

\begin{tabular}{|c|c|c|}
\hline $\begin{array}{l}\text { Seeking } \\
\text { autonomy } \\
\text { event }\end{array}$ & Perceived constraint & $\begin{array}{l}\text { Breaking free of or breaking up the perceived } \\
\text { constraint }\end{array}$ \\
\hline \multirow[t]{3}{*}{$\begin{array}{l}\text { 05-No humans } \\
\text { on Mars }\end{array}$} & $\begin{array}{l}\text { Humans have no way to travel to } \\
\text { Mars, and there are no credible } \\
\text { projects to get humans to Mars. }\end{array}$ & \multirow{2}{*}{$\begin{array}{l}\text { Develop systems capable of taking humans to Mars and } \\
\text { sustaining a city there: "The thing that's important in the } \\
\text { long run is establishing a self-sustaining base on Mars. } \\
\text { In order for that to work-in order to have a self- } \\
\text { sustaining city on Mars-there would need to be } \\
\text { millions of tons of equipment and probably millions of } \\
\text { people" (p. 332). }\end{array}$} \\
\hline & \multirow{2}{*}{$\begin{array}{l}\text { Musk states: "At first I thought NASA } \\
\text { just had a badly designed website. } \\
\text { Why else couldn't you find this critical } \\
\text { piece of information that would } \\
\text { obviously be the first thing you'd want } \\
\text { to know when you go to NASA.gov? } \\
\text { But, it turned out, NASA had no plans } \\
\text { for Mars. In fact, they had a crazy } \\
\text { policy that didn't even let them talk } \\
\text { about sending humans to Mars" } \\
\text { (Diamandis \& Kotler, p. 118). }\end{array}$} & \\
\hline & & $\begin{array}{l}\text { "NASA researchers studying the Dragon design have } \\
\text { noticed several features of the capsule that appear to } \\
\text { have been purpose built from the get-go to } \\
\text { accommodate a landing on Mars... It could be feasible } \\
\text { for NASA to fund a mission to Mars in which a Dragon } \\
\text { capsule picks up samples and returns them to Earth" } \\
\text { (Diamandis \& Kotler, p. 118) }\end{array}$ \\
\hline \multirow[t]{4}{*}{$\begin{array}{l}\text { 06-Space is } \\
\text { "special"; not } \\
\text { like other } \\
\text { industries }\end{array}$} & \multirow[t]{2}{*}{$\begin{array}{l}\text { Rockets and capsules are used only } \\
\text { once: "So long as we continue to } \\
\text { throw away rockets and spacecraft, } \\
\text { we will never have true access to } \\
\text { space" (p. 257). }\end{array}$} & $\begin{array}{l}\text { Reusable rockets: Musk is "testing rockets that can } \\
\text { push their payload to space and then return to Earth } \\
\text { and land with supreme accuracy on a pad floating at } \\
\text { sea or even their original launchpad" (p. } 217 \text { ) }\end{array}$ \\
\hline & & \\
\hline & \multirow[t]{2}{*}{$\begin{array}{l}\text { Anything designed and built for space } \\
\text { is expensive and takes a long time ( } p \text {. } \\
114)\end{array}$} & $\begin{array}{l}\text { could carry the Dragon capsule into space and that the } \\
\text { capsule could be recovered" (p. 254). "The Dragon } 2 \\
\text { will ... [use] SuperDraco engines and thrusters to come } \\
\text { to a gentle stop on the ground. No more landings at } \\
\text { sea. No more throwing spaceships away" (p. } 257\end{array}$ \\
\hline & & $\begin{array}{l}\text { Massive cost reduction: "Musk's goal is to use } \\
\text { manufacturing breakthroughs and launchpad advances } \\
\text { to create a drastic drop in the cost of getting things to } \\
\text { space" (p. 217). }\end{array}$ \\
\hline
\end{tabular}

Table 27 (part 1 of 2) and Table 28 (part 2 of 2) summarize the seven authoring

events for Musk. 
Table 27: Musk: authoring events (part 1 of 2)

\begin{tabular}{|c|c|c|}
\hline Authoring event & Old status quo to be changed & New arrangement supporting change-creating intent \\
\hline \multirow[t]{2}{*}{$\begin{array}{l}\text { 01-Join the } \\
\text { network }\end{array}$} & $\begin{array}{l}\text { Prior to } 2001 \text {, Musk was an } \\
\text { outsider to the space industry. }\end{array}$ & $\begin{array}{l}\text { Musk's } 2001 \text { move from Silicon Valley to Los Angeles } \\
\text { gave him access to the space industry (p. 97). }\end{array}$ \\
\hline & & $\begin{array}{l}\text { Musk joined social networks: donated to the Mars } \\
\text { Society and Mars research (p. 100); joined the Mars } \\
\text { Society board of directors; announced founding the Life } \\
\text { to Mars Foundation (p. 102); discussed investing } \$ 20 M \\
\text { to } \$ 30 \text { M in a Mars project (p. 103); built connections with } \\
\text { ambitious engineers (p. 111). }\end{array}$ \\
\hline
\end{tabular}

02-Attempt to buy Launches required specialized

Russian ICBMs launch vehicles such as Russian Soyuz rockets.

In 2002, "Musk intended to buy a refurbished

intercontinental ballistic missile, or ICBM, from the Russians and use that as his launch vehicle" (p. 104).

Musk met with Russians twice in Moscow and once in California. Musk was willing to pay $\$ 20 \mathrm{M}$ for three ICMBs, but did not reach a deal (pp. 106-107).

03-SpaceX is a Silicon Valley space company
"Musk felt that the space industry had not really evolved in about fifty years. The aerospace companies had little competition and tended to make supremely expensive products that achieved maximum performance. They were building a Ferrari for every launch" (p. 114).

\section{Founded SpaceX in 2002.}

"[Musk] had taken much of the Silicon Valley ethic behind moving quickly and running organizations free of bureaucratic hierarchies and applied it to improving big, fantastic machines and chasing things that had the potential to be the real breakthroughs we'd been missing" (p. 14).

"SpaceX was to be America's attempt at a clean slate in the rocket business, a modernized reset" (p. 114)

Musk set "insanely ambitious timelines" (p. 114), used open-concept offices where scientists and engineers worked alongside welders and machinists ( $p$ 113), hired young overachievers fresh from college for rank-and-file engineers and poached top engineers from Boeing, Lockheed Martin, and Orbital Sciences (p. 120), contracted with suppliers outside of the aerospace sector (p. 132), and "never relented in asking his employees to do more and be better" (p. 131).

"The only way to keep up ... was to do what SpaceX had promised from the beginning: operate in the spirit of a Silicon Valley start-up" (p. 130).

04-Launch facility Launch tests happen at air force bases; high cost; long wait times.
Procured unconventional launch facility: A former U.S. military missile test site on the Kwajalein Island (Kwaj), an atoll between Guam and Hawaii in the Marshall Islands, and adapted the site to their needs (p. 135). 
Table 28: Musk: authoring events (part 2 of 2)

\begin{tabular}{|c|c|c|}
\hline Authoring event & Old status quo to be changed & New arrangement supporting change-creating intent \\
\hline $\begin{array}{l}\text { 05-SpaceX } \\
\text { "system" }\end{array}$ & $\begin{array}{l}\text { Designing and operating systems } \\
\text { for space was the exclusive } \\
\text { domain of government, the } \\
\text { military, defence contractors, and } \\
\text { incumbent aerospace companies. }\end{array}$ & $\begin{array}{l}\text { SpaceX developed an end-to-end platform of launch } \\
\text { vehicles, capsules, and engines-designed, } \\
\text { manufactured, assembled, and tested at SpaceX } \\
\text { facilities: } \\
\text { - Falcon launch vehicles (rockets): Falcon 1, Falcon 5, } \\
\text { Falcon 9, Falcon Heavy, ITS Launch Vehicle } \\
\text { - Dragon capsules (spacecraft): Dragon, Dragon } 2 \\
\text { - Engines: Merlin, Kestrel, Draco, SuperDraco } \\
\text { Insourced capabilities in-house: "SpaceX increased its } \\
\text { internal welding capabilities so that it could make the fuel } \\
\text { tanks in [a SpaceX facility] and ditch Spincraft [a } \\
\text { suppler]" (p. 132). } \\
\text { "[Musk] doesn't want to handle a few launches per year } \\
\text { or to rely on government contracts for survival. Musk's } \\
\text { goal is to use manufacturing breakthroughs and } \\
\text { launchpad advances to create a drastic drop in the cost } \\
\text { of getting things to space" (p. } 217 \text { ) }\end{array}$ \\
\hline 06-Contracts & $\begin{array}{l}\text { NASA contracts only with } \\
\text { traditional aerospace and military } \\
\text { suppliers. }\end{array}$ & $\begin{array}{l}\text { SpaceX contracted with NASA and the U.S. Military to } \\
\text { develop technology (2006) and operate missions (2008). } \\
\text { In 2012, a Dragon capsule became the first private } \\
\text { spacecraft to dock with the International Space Station } \\
\text { (Chang, 2012). }\end{array}$ \\
\hline $\begin{array}{l}\text { 07-Humans as an } \\
\text { interplanetary } \\
\text { species }\end{array}$ & $\begin{array}{l}\text { Neither human civilization nor the } \\
\text { human species would survive a } \\
\text { catastrophic event rendering } \\
\text { Earth unfit for human life. }\end{array}$ & $\begin{array}{l}\text { "Musk's ultimate goal, though, remains turning humans } \\
\text { into an interplanetary species. This may sound silly to } \\
\text { some, but there can be no doubt that this is Musk's } \\
\text { raison d'etre" (p. 331) }\end{array}$ \\
\hline
\end{tabular}

Table 29 summarizes the four making declarations events for Musk. 
Table 29: Musk: making declarations

\begin{tabular}{|c|c|c|c|c|}
\hline $\begin{array}{l}\text { Making } \\
\text { declaration } \\
\text { s event }\end{array}$ & $\begin{array}{l}\text { Statement of intent to } \\
\text { create change }\end{array}$ & $\begin{array}{l}\text { Forms of the } \\
\text { discursive or } \\
\text { rhetorical acts }\end{array}$ & $\begin{array}{l}\text { Contestations from } \\
\text { others }\end{array}$ & $\begin{array}{l}\text { Overcoming } \\
\text { contestations }\end{array}$ \\
\hline $\begin{array}{l}\text { 01-Build } \\
\text { own rocket }\end{array}$ & $\begin{array}{l}\text { SpaceX will build its own } \\
\text { rocket to carry smaller } \\
\text { payloads to space. } \\
\text { SpaceX website: "SpaceX } \\
\text { is privately developing the } \\
\text { entire Falcon rocket from } \\
\text { the ground up, including } \\
\text { both engines, the turbo- } \\
\text { pump, the cryogenic tank } \\
\text { structure and the guidance } \\
\text { system" (p. 118). }\end{array}$ & $\begin{array}{l}\text { After failing to } \\
\text { secure a } \\
\text { Russian rocket, } \\
\text { Musk said "I } \\
\text { think we can } \\
\text { build this rocket } \\
\text { ourselves" (p. } \\
\text { 107). } \\
\text { Website. Public } \\
\text { statements. }\end{array}$ & $\begin{array}{l}\text { "As word traveled around } \\
\text { the space community about } \\
\text { Musk's plans, there was a } \\
\text { collective ho-hum [from } \\
\text { people who had seen this } \\
\text { before]... The techies } \\
\text { usually ended up spending } \\
\text { the rich guy's money for two } \\
\text { years, and then the rich guy } \\
\text { gets bored and shuts the } \\
\text { thing down" (p. 108). }\end{array}$ & $\begin{array}{l}\text { Musk persisted, } \\
\text { spending his own } \\
\text { money. }\end{array}$ \\
\hline $\begin{array}{l}\text { 02-We will } \\
\text { persevere }\end{array}$ & $\begin{array}{l}\text { Musk vowed to continue } \\
\text { despite three failed test } \\
\text { launches and severe time } \\
\text { and cost overruns. } \\
\text { Musk: "'I will spend my last } \\
\text { dollar on these companies. } \\
\text { If we have to move into } \\
\text { Justine's parents' } \\
\text { basement, we'll do it." (pp. } \\
\text { 198-199). }\end{array}$ & $\begin{array}{l}\text { Confident } \\
\text { statements to } \\
\text { family, } \\
\text { employees and } \\
\text { the public after } \\
\text { each early } \\
\text { failure. }\end{array}$ & $\begin{array}{l}\text { Doubts after three failed } \\
\text { launches and missed } \\
\text { targets. } \\
\text { "It took six years-about } \\
\text { four and a half more than } \\
\text { Musk had once planned- } \\
\text { and five hundred people to } \\
\text { make this miracle of } \\
\text { modern science and } \\
\text { business happen" }\end{array}$ & $\begin{array}{l}\text { The fourth test launch } \\
\text { succeed in 2008; } \\
\text { "SpaceX simply did } \\
\text { not have enough } \\
\text { money to try a fifth } \\
\text { flight" (p. 200). } \\
\text { "When the launch } \\
\text { was successful, } \\
\text { everyone burst into } \\
\text { tears" (p. 203). }\end{array}$ \\
\hline $\begin{array}{l}\text { 03-New } \\
\text { paradigm in } \\
\text { the space } \\
\text { industry }\end{array}$ & $\begin{array}{l}\text { SpaceX will do things } \\
\text { differently from government } \\
\text { space agencies and } \\
\text { incumbent aerospace } \\
\text { companies. } \\
\text { Massive cost reduction is } \\
\text { necessary and possible. } \\
\text { Musk: "Even if the } \\
\text { probability of success is } \\
\text { low, if the objective is really } \\
\text { important, it's worth doing" } \\
\text { (Diamandis \& Kotler, p. } \\
\text { 122) }\end{array}$ & $\begin{array}{l}\text { Statements to } \\
\text { employees and } \\
\text { the public about } \\
\text { doing things } \\
\text { differently. }\end{array}$ & $\begin{array}{l}\text { Tom Mueller: "People } \\
\text { thought we were crazy. At } \\
\text { TRW, I had an army of } \\
\text { people and government } \\
\text { funding. Now were were } \\
\text { going to make a low-cost } \\
\text { rocket from scratch with a } \\
\text { small team" (p. 116). } \\
\text { "The whole situation was } \\
\text { ludicrous. A start-up rocket } \\
\text { company had ended up in } \\
\text { the middle of nowhere } \\
\text { trying to pull off one of the } \\
\text { most difficult feats known to } \\
\text { man" (p. 137). }\end{array}$ & $\begin{array}{l}\text { "SpaceX spent } \$ 2.5 \\
\text { billion to get four } \\
\text { Dragon capsules to } \\
\text { the ISS, nine flights } \\
\text { with the Falcon } 9 \text {, and } \\
\text { five flights with the } \\
\text { Falcon } 1 . \text { It's a price- } \\
\text { per-launch total that } \\
\text { the rest of the players } \\
\text { in the industry cannot } \\
\text { comprehend let alone } \\
\text { aspire to." }\end{array}$ \\
\hline $\begin{array}{l}\text { 04-Maintain } \\
\text { control; no } \\
\text { IPO }\end{array}$ & $\begin{array}{l}\text { SpaceX will remain } \\
\text { privately held to pursue its } \\
\text { ambitious goals of making } \\
\text { humans an interplanetary } \\
\text { species. }\end{array}$ & $\begin{array}{l}\text { Letter to } \\
\text { SpaceX } \\
\text { employees } \\
\text { about the timing } \\
\text { of going public } \\
\text { (p. 260). } \\
\text { Consistent } \\
\text { statements } \\
\text { about staying } \\
\text { private. }\end{array}$ & $\begin{array}{l}\text { "Yes, but I could make } \\
\text { more money if we were } \\
\text { public" }\end{array}$ & $\begin{array}{l}\text { "For those who are } \\
\text { under the impression } \\
\text { that they are so clever } \\
\text { that they can } \\
\text { outsmart public } \\
\text { market investors and } \\
\text { would sell SpaceX } \\
\text { stock at the "right } \\
\text { time," let me relieve } \\
\text { you of any such } \\
\text { notion..." }\end{array}$ \\
\hline
\end{tabular}




\subsection{Organizational forms}

The method for organization form coding - the sixth step of the research method and the third of the three rounds of coding - was previously explained in section 3.6. Recall that organizational form refers here to the three broad forms of organizing innovation and production identified by Moore (2006) and previously summarized in Table 9 - the traditional forms of markets and organizational hierarchies (q.v., Smith, 1776; Chandler, 1977; Williamson, 1975; Scott \& Davis, 2007), and business ecosystems (Moore, 1993, 1996; Iansiti \& Levien, 2004; Muegge, 2011a, 2011b, 2013; Muegge \& Mezen, 2017).

Table 30 reports the results of the organizational form coding for Branson. Only events with organizational form codes assigned are included in the tables; events with no organizational form codes are omitted.

Table 30: Branson: Organizational forms of emancipation events

\begin{tabular}{|c|c|c|c|c|}
\hline Event description & 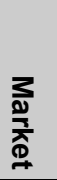 & 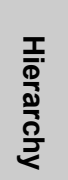 & 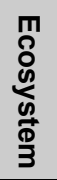 & Rationale \\
\hline Branson-A-01-Virgin Galactic & $\bullet$ & ○ & & $\begin{array}{l}\text { Licensing and supply chain (market) } \\
\text { Joint venture (hybrid; market; hierarchy) } \\
\text { Own venture (hierarchy) }\end{array}$ \\
\hline $\begin{array}{l}\text { Branson-MD-01-Maintain full control of } \\
\text { company }\end{array}$ & & $\bullet$ & & $\begin{array}{l}\text { "Perfect control" is the ideal relationship sought } \\
\text { through the hierarchy form. }\end{array}$ \\
\hline •: Strongly evident (1) & 1 & 1 & & \\
\hline ○: Evident (0.5) & & 1 & & \\
\hline Total count & 1 & 2 & & \\
\hline Weighted score $(\bullet=1, \quad \circ=0.5)$ & 1 & 1.5 & 0 & Hierarchy / market \\
\hline Weighted score (authoring only) & 1 & 0.5 & 0 & Market / hierarchy \\
\hline
\end{tabular}


Two of the seven Branson emancipation events (28.6\%) were coded to organizational forms. Emancipation events were associated with both market and hierarchy forms; the business ecosystem form did not feature in Branson emancipation events. Across all event types, Branson most often employed the hierarchy form. Considering only authoring events, Branson favoured the market form.

Table 31 present the results of organizational form coding for Diamandis.

Table 31: Diamandis: Organizational forms of emancipation events

\begin{tabular}{|c|c|c|c|c|}
\hline Event description & 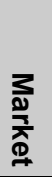 & 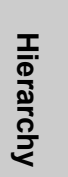 & 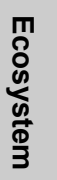 & Rationale \\
\hline $\begin{array}{l}\text { Diamandis-SA-01-NASA cannot get } m e \text { to } \\
\text { space }\end{array}$ & & • & ○ & $\begin{array}{l}\text { Breaking free by founding new private ventures } \\
\text { (hierarchy) and motivating innovation in novel } \\
\text { ways (some are ecosystems, not all) }\end{array}$ \\
\hline $\begin{array}{l}\text { Diamandis-A-01-Incentive prizes to solve } \\
\text { global challenges }\end{array}$ & & & & $\begin{array}{l}\text { "Facilitate coordination of innovation" is the } \\
\text { function of a business ecosystem }\end{array}$ \\
\hline $\begin{array}{l}\text { Diamandis-A-02-Launch and grow space } \\
\text { companies }\end{array}$ & & o & $\bullet$ & $\begin{array}{l}\text { Founding ventures (hierarchy). } \\
\text { "Help" from others (ecosystem) }\end{array}$ \\
\hline $\begin{array}{l}\text { Diamandis-A-03-Enable others to solve big } \\
\text { problems }\end{array}$ & & & - & $\begin{array}{l}\text { Enabling others to solve big problems and get } \\
\text { help from "today's hyperconnected crowd" } \\
\text { (ecosystem) }\end{array}$ \\
\hline Diamandis-MD-02-Future of abundance & & & ○ & $\begin{array}{l}\text { "Give *us* the ability to solve..." = a multitude of } \\
\text { contributors coming together (ecosystem) }\end{array}$ \\
\hline $\begin{array}{l}\text { Diamandis-MD-03-Bold entrepreneurs can } \\
\text { solve big problems and create wealth }\end{array}$ & & ○ & & Found companies (hierarchy) \\
\hline •: Strongly evident (1) & & 1 & 3 & \\
\hline ০: Evident (0.5) & & 2 & 2 & \\
\hline Total count & & 3 & 5 & \\
\hline Weighted score $(\bullet=1, \quad \circ=0.5)$ & 0 & 2 & 4 & Ecosystem / hierarchy \\
\hline Weighted score (authoring only) & 0 & 0.5 & 3 & Ecosystem / hierarchy \\
\hline
\end{tabular}


Six of the eight Diamandis emancipation events were coded to organizational forms (75\%). Emancipation events were associated with both hierarchy and business ecosystem forms; the market form did not feature in Diamandis emancipation events. Across all event types, and considering only the authoring events, Diamandis most often employed the business ecosystem form, followed by the hierarchy form.

Table 32 present the results of the organizational form coding for Musk.

Fourteen of the seventeen Musk emancipation events were coded to organizational forms $(82.4 \%)$. Emancipation events were associated with all three organizational forms - markets, hierarchies, and business ecosystems - however, the distribution was uneven. Across all event types, and considering only the subset of authoring events, Musk most often employed the hierarchy form, followed by market, with business ecosystems third.

Evidently, all three organizational forms can be emancipating in the sense of featuring within the emancipation processes of entrepreneuring. 
Table 32: Musk: Organizational forms of emancipation events

\begin{tabular}{|c|c|c|c|c|}
\hline Event description & $\underset{\substack{3 \\
\stackrel{7}{2}}}{\stackrel{3}{0}}$ & 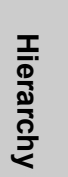 & 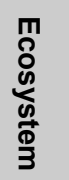 & Rationale \\
\hline $\begin{array}{l}\text { Musk-SA-03-CEO in control of own } \\
\text { company }\end{array}$ & & $\bullet$ & & $\begin{array}{l}\text { Be in charge. Own money. Stay private. } \\
\text { (hierarchy) }\end{array}$ \\
\hline $\begin{array}{l}\text { Musk-SA-04-Must use Russian launch } \\
\text { vehicles }\end{array}$ & & $\bullet$ & & In-source from a supplier (hierarchy) \\
\hline $\begin{array}{l}\text { Musk-SA-06-Space is "special"; not like } \\
\text { other industries }\end{array}$ & & ○ & & Musk's company is unlike others (hierarchy) \\
\hline Musk-A-01-Join the network & & & o & Some ecosystem activities to join the network \\
\hline Musk-A-02-Attempt to buy Russian ICBMs & o & & & Market transaction; failed \\
\hline $\begin{array}{l}\text { Musk-A-03-SpaceX is a Silicon Valley space } \\
\text { company }\end{array}$ & & • & & $\begin{array}{l}\text { Founded a space company (hierarchy); } \\
\text { founder in control; demanding }\end{array}$ \\
\hline Musk-A-04-Launch facility & o & $\bullet$ & & $\begin{array}{l}\text { Procurement (market) but also breaking free of } \\
\text { established supply chains; develop own facility } \\
\text { about internal control (hierarchy) }\end{array}$ \\
\hline Musk-A-05-SpaceX "system" & & $\bullet$ & & Development of systems in-house (hierarchy) \\
\hline Musk-A-06-Contracts & o & & & Competitive contracts (market) \\
\hline $\begin{array}{l}\text { Musk-A-07-Humans as an interplanetary } \\
\text { species }\end{array}$ & & ○ & & $\begin{array}{l}\text { Musk using SpaceX (hierarchy) to work towards } \\
\text { a bold goal }\end{array}$ \\
\hline Musk-MD-01-Build own rocket & & $\bullet$ & & Development of systems in-house (hierarchy) \\
\hline Musk-MD-02-We will persevere & & $\bullet$ & & Control; Musk's money (hierarchy) \\
\hline $\begin{array}{l}\text { Musk-MD-03-New paradigm in the space } \\
\text { industry }\end{array}$ & & $\bullet$ & & SpaceX will do things differently (hierarchy) \\
\hline Musk-MD-04-Maintain control; no IPO & & $\bullet$ & & $\begin{array}{l}\text { "Perfect control" is the ideal relationship sought } \\
\text { through the hierarchy form. }\end{array}$ \\
\hline •: Strongly evident (1) & & 9 & & \\
\hline ○: Evident $(0.5)$ & 3 & 2 & 1 & \\
\hline Total count & 3 & 11 & 1 & \\
\hline Weighted score $(\bullet=1, \quad \circ=0.5)$ & 1.5 & 10 & 0.5 & Hierarchy / market/ ecosystem \\
\hline Weighted score (authoring only) & 1.5 & 3.5 & 0.5 & Hierarchy/ market / ecosystem \\
\hline
\end{tabular}




\subsection{Cross-case comparisons}

The final step of the research method is cross-case analysis. The following three subsections each examine one of the three event types across all three cases. A fourth subsection compares the three cases with respect to organizational forms. A fifth subsection develops an explanation for differences in organizational forms.

\subsubsection{Seeking autonomy}

The seeking autonomy results were reported in Table 19 (Branson), Table 22 (Diamandis), and Table 25 and Table 26 (Musk). Consistent with the emancipation perspective on entrepreneuring, seeking autonomy was impetus for action for all three entrepreneurs. Each sought to breaking free of or break up perceived constraints in their environment.

Two entrepreneurs felt constrained by the slow pace of progress and limitations of government space agencies: Diamandis by the realization that NASA would never get him to space, and Musk by the low shared expectations regarding progress in space, the lack of credible projects to get humans to Mars, the lack of domestic and lower-cost alternatives to the Russian Soyuz launch vehicles, and the high cost structures imposed by current practices such as using rockets and capsules only once.

Two entrepreneurs felt constrained by the low-impact problems addressed by most businesses: Branson sought to improve improve lives by making a positive difference, and Musk sought to do something that matters for the entire human species. In particular, Musk felt constrained by the vulnerabilities of being a single-planet species, and sought to break free by becoming a multi-planet species. 
All three entrepreneurs were unique in some way. Branson, uniquely, sought to break free of boredom by pursuing fun projects and business opportunities. Diamandis, uniquely, sought to break free of money as the de facto reward to motivate action by promoting and applying intrinsic rewards that unlock higher performance. Musk uniquely, sought to break free of control by investors, who had replaced him as CEO in two previous companies.

\subsubsection{Authoring}

The authoring results were reported in Table 20 (Branson), Table 23 (Diamandis), and Table 27 and Table 28 (Musk). Consistent with the emancipation perspective on entrepreneuring, all three entrepreneurs took ownership by defining new arrangements to replace an old status quo.

Each entrepreneur founded a new venture related to commercial spaceflight. Although the ventures differed with respect to product and service offers, each followed directly from the impetus of seeking autonomy by the founding entrepreneur. Branson's Virgin Galactic was exciting and may improve lives by “opening up space to the rest of us". Diamandis' XPRIZE opened up space to private companies, and motivated with progress in novel ways. Musk's SpaceX would make space seem exciting again, while developing technology that could send people to Mars, with Musk in control of his own privately-held venture.

Some authoring events were internal to the space venture. For example, both Branson and Musk established particular cultures within their space ventures. However, the Virgin Way of Branson was quite different from Silicon Valley culture of Musk. 
Other authoring events were external the space venture. Some of the new arrangements of Diamandis were intended to enable others to solve big problems.

\subsubsection{Making declarations}

The making declarations events were reported in Table 21 (Branson), Table 24 (Diamandis), and Table 29 (Musk). Consistent with the emancipation perspective on entrepreneuring, all three entrepreneurs made unambiguous discursive and rhetorical acts regarding intentions to make change. Branson's declarations were about maintaining control of his companies and leading The Virgin Way. Diamandis' declarations were about intent to launch his own bold space ventures, and about inspiring others to higher achievement and ambition. Musk's declarations were about technological progress, perseverance, massive cost reduction, and remaining in control to maintain focus on ambitious goals. For each entrepreneur, the making declarations events exposed differences, generated supported, and established expectations.

\subsubsection{Organizational forms and ecosystem events}

The organizational form results reported in Table 30, Table 31, and Table 32 illustrate differences between the three cases. For each case, a different organizational form was most prominent in the emancipation events. For Branson and Virgin Galactic, the market form was most prominent. For Diamandis and XPRIZE, the business ecosystem form was most prominent. For Musk and SpaceX, the hierarchy was most prominent.

Of the twenty-two emancipation events coded to organizational forms, six events were coded to business ecosystems. None of Branson's events were coded to business 
ecosystems. Five of Diamandis' events were coded to business ecosystems; two of these were evident (one each for seeking autonomy and making declarations) and three were strongly evident (all authoring events). Finally, one of Musk's authoring events was coded to business ecosystems.

The following three tables each summarize the emancipation events coded to the business ecosystem organizational form for each of the three core elements of the emancipation perspective - one seeking autonomy event in Table 33, four authoring events in Table 34, and one making declarations event in Table 35.

Table 33: Seeking autonomy events coded to the business ecosystem form

\begin{tabular}{|c|c|c|}
\hline Event & Perceived constraint & $\begin{array}{l}\text { Breaking free of or breaking up the perceived } \\
\text { constraint }\end{array}$ \\
\hline $\begin{array}{l}\text { Diamandis-SA- } \\
\text { 01-NASA } \\
\text { cannot get me }\end{array}$ & \multirow{3}{*}{$\begin{array}{l}\text { "I was only eight years old when Apollo } 11 \\
\text { landed on the moon, and i decided then } \\
\text { and there that going into space was what I } \\
\text { wanted to do with my life. I was in my } \\
\text { early twenties when I realized NASA was } \\
\text { never going to get me there. Constrained } \\
\text { by government spending and frightened by } \\
\text { the risk of failure, the space agency had } \\
\text { become a military-industrial jobs program } \\
\text { unlikely to return to the Moon or push } \\
\text { onward to Mars" (p. 96). }\end{array}$} & $\begin{array}{l}\text { Co-founded Students for the Exploration and } \\
\text { Development of Space (SEDS) in } 1980 \text { while an } \\
\text { undergraduate to link people interested in space. }\end{array}$ \\
\hline & & $\begin{array}{l}\text { Started private space ventures without } \\
\text { government help. }\end{array}$ \\
\hline $\begin{array}{l}\text { [Evident: } \\
\text { breaking free by } \\
\text { motivating } \\
\text { innovation in } \\
\text { novel ways] }\end{array}$ & & $\begin{array}{l}\text { Explored novel approaches to motivate innovation } \\
\text { in spaceflight from people and private companies: } \\
\text { "Have a vision for tomorrow, pull yourself toward } \\
\text { it. I wanted a future that included private } \\
\text { commercial space flight, so I launched the } \\
\text { XPRIZE" (p. 109). }\end{array}$ \\
\hline
\end{tabular}

In the event "NASA cannot get me to space" (Diamandis-SA-01), the constraint is that NASA, then the only American entity with the capability to transport humans to space, would never agree to transport the young Diamandis. To break up this constraint, human space travel could no longer be solely the domain of government agencies. 
Table 34: Authoring events coded to the business ecosystem form

\begin{tabular}{ll}
\hline Event & Old status quo to be changed \\
\hline $\begin{array}{l}\text { Diamandis-A- } \\
\text { 01-Incentive } \\
\text { prizes to solve } \\
\text { global } \\
\text { challenges }\end{array}$ & $\begin{array}{l}\text { "Before the Ansari XPRIZE, few } \\
\text { investors seriously considered the } \\
\text { market for commercial space flight; } \\
\text { it was assumed to be the sole } \\
\text { province of governments" (p. 246); } \\
\text { market failures hindered } \\
\text { investment; entrenched incumbents }\end{array}$ \\
$\begin{array}{ll}\text { [Strongly } & \text { limited progress. } \\
\text { evident: } & \text { Similar obstacles impede other } \\
\text { organize to } & \text { global challenges. } \\
\text { facilitate } & \\
\text { coordination of } \\
\text { innovation] }\end{array}$ & $\begin{array}{l}\text { Progress in space was moving too } \\
\text { Diamandis-A- }\end{array}$ \\
$\begin{array}{l}\text { 02-Launch and } \\
\text { grow space }\end{array}$ & $\begin{array}{l}\text { slowly (p. 97). Government space } \\
\text { agencies were unlikely to return to }\end{array}$ \\
the Moon or push onward to Mars \\
(p. 96).
\end{tabular}

[Strongly evident: mobilize help from others]

New arrangement supporting change-creating intent

Founded the $X$ PRIZE Foundation in in 1995, and launched the first X Prize competition in 1996: a US\$10M prize for the first non-government organization to launch a reusable manned spacecraft into space twice within two weeks. The prize, later renamed the Ansari $X$ Prize after a major donor, was won in 2004 using the experimental spaceplane SpaceShipOne.

Incentive prizes spur innovation beyond value of the prize: "For the exponential entrepreneur, the incentive prize is a mechanism for solving a personal challenge or a global injustice or bringing a new technology into existence" ( $p$. 244). Donors can motivate "radical breakthroughs for the benefit of humanity."

"If we're going to boldly go, it was going to have to be without the help of government. Thus I devoted the next thirty years to starting private ventures that I thought would open the space frontier" (p. 96):

- International Space University (1987)

- Zero Gravity Corporation (1994)

- $\quad$ X PRIZE Foundation (1995)

- $\quad$ Space Adventures Limited (1988)

- $\quad$ Blast Off Corporation (2000-2001)

- $\quad$ Planetary Resources (2012)

Regarding asteroid mining: "To open up space ... we needed to exploit the same economic engine that had opened every previous frontier: the search for resources" (p. 97). "To pull off such a massive moonshot, we're going to need help, a lot of help. And thus our first challengeconvincing anyone our dream was doable" (p. 98).

Diamandis-A03-Enable others to solve big problems

[Strongly evident: enable others to solve big problems and get help from the crowd]
"Thousands of years ago, it was only kings, pharaohs, and emperors who had the ability to solve largescale problems. Hundreds of years ago, this power expanded to the industrialists who built our transportation systems and financial institutions" (p. xii).
Co-founded Singularity University in 2008 to teach exponential thinking and how to solve big problems.

Codified knowledge through two books, Abundance (2012) and Bold (2015), and a TED talk (2012):

"Today, the ability to solve such problems has been thoroughly democratized. Right now, and for the first time ever, a passionate and committed individual has access to the technology, minds, and capital required to take on any challenge" (p. xii).

Exponential entrepreneurs can "make their boldest dreams come true" (p. xiii) by getting help from "today's hyperconnected crowd" (p. xiii) in four ways:

(1) crowdsourcing, (2) crowdfunding, (3) building communities, and (4) incentive competitions.
Musk-A-01Join the network

[Evident: actions to join the network]
Prior to 2001, Musk was an outsider Musk's 2001 move from Silicon Valley to Los Angeles to the space industry. gave him access to the space industry (p. 97) Musk joined social networks: donated to the Mars Society and Mars research (p. 100); joined the Mars Society board of directors; announced founding the Life to Mars Foundation (p. 102); discussed investing \$20M to \$30M in a Mars project (p. 103); built connections with ambitious engineers (p. 111).

\section{Copyright (C) 2018 Ewan Reid}


The four authoring events coded to the business ecosystem organizational form all involve defining new relationships, arrangements, and rules of engagements related to ecosystem structure and constructs (from section 2.2); in each event, the focal entrepreneur uses ecosystem ideas as a means to take ownership and change positions of power, and thereby create change. In "incentive prizes to solve global challenges" (Diamandis-A-01), Diamandis founded a new keystone organization as a hub within a network of innovators and donors, regulated and coordinated by prize competitions. In "launch and grow space companies" (Diamandis-A-02), Diamandis mobilized others for help around a shared vision, defining new relationships with private sector actors outside of government space agencies. In "enable others to solve big problems" (Diamandis-A03), Diamandis empowered "exponential entrepreneurs" with capabilities to enact change that were previously unavailable, by mobilizing help from others. In "join the network" (Musk-A-01), Musk transitions from a space industry outsider to a space industry insider by building new relationships and by donating resources within established social networks. Each ecosystem authoring event changed an old status quo, and brought about a new arrangement supporting the entrepreneur's change-creating intent. 
Table 35: Making declarations events coded to the business ecosystem form

\begin{tabular}{|c|c|c|c|c|}
\hline $\begin{array}{l}\text { Making } \\
\text { declarations } \\
\text { event }\end{array}$ & $\begin{array}{l}\text { Statement of intent to create } \\
\text { change }\end{array}$ & $\begin{array}{l}\text { Forms of the } \\
\text { discursive or } \\
\text { rhetorical acts }\end{array}$ & $\begin{array}{l}\text { Contestations } \\
\text { from others }\end{array}$ & $\begin{array}{l}\text { Overcoming } \\
\text { contestations }\end{array}$ \\
\hline $\begin{array}{l}\text { Diamandis-MD- } \\
\text { 02-Future of } \\
\text { abundance } \\
\text { [Evident: bring } \\
\text { together a } \\
\text { multitude of } \\
\text { contributors to } \\
\text { solve problems] }\end{array}$ & $\begin{array}{l}\text { "What I witnessed from the helm of } \\
\text { [XPRIZE and Singularity University] } \\
\text { was a world where the basic } \\
\text { necessities of life were becoming } \\
\text { cheaper and globally accessible... } \\
\text { Four potent emerging forces- } \\
\text { exponential technologies, the DIY } \\
\text { innovator, technophilanthropists, } \\
\text { and the rising billion-give us the } \\
\text { ability to solve many of the world's } \\
\text { grandest challenges over the next } \\
\text { two to three decades. That is, we } \\
\text { will soon have the power to meet } \\
\text { and exceed the basic needs of } \\
\text { every man, woman, and child on } \\
\text { the planet" (p. xi) }\end{array}$ & $\begin{array}{l}\text { Co-authored } \\
\text { book: } \\
\text { Abundance } \\
(2012)\end{array}$ & $\begin{array}{l}\text { Exponential } \\
\text { technologies } \\
\text { grow slowly at } \\
\text { first when the } \\
\text { doubling is } \\
\text { small; can be } \\
\text { easily } \\
\text { dismissed or } \\
\text { overlooked. }\end{array}$ & $\begin{array}{l}\text { "Exponential } \\
\text { technology is not just } \\
\text { putting linear } \\
\text { companies out of } \\
\text { business, it's also } \\
\text { putting linear industries } \\
\text { out of business. It's } \\
\text { shifting the entire } \\
\text { landscape, disrupting } \\
\text { traditional industrial } \\
\text { processes" (p. 17). }\end{array}$ \\
\hline
\end{tabular}

In the "future of abundance" event (Diamandis-MD-02), Diamandis described an achievable future to mobilize support from "a multitude of contributors" to bring about that future by making it happen. Diamandis reshaped interpretations and expectations of small changes today that could be signals of exponential technologies in the future - the technologies could help solve the worlds biggest problems and disrupt the status quo.

\subsubsection{Explanation of organizational forms}

The differences between the three cases suggest two partial and reinforcing explanations for why different entrepreneurs favoured different organizational forms for their emancipation actions. Of particular interest here is theorizing, by means of explanation-building from theory and case evidence (Yin, 2014), about why the business ecosystem organizational form featured prominently for Diamandis and less prominently for Musk and Branson. Both explanations are tentative, likely incomplete, and in need of further validation, inferred only from the results of these three cases. 
The first explanation relates to the nature of the perceived constraints and the change-creating intent of the entrepreneur - specifically about control. Branson and Musk both expressed a keen desire to control their organizations. Branson declared that he would maintain full control his companies (Branson-MD-01), keeping Virgin Galactic privately-held to maintain freedom and independence from shareholders. Musk sought to break from control of investors (Musk-SA-03) after two previous companies "had been ripped away ... and given to someone else to run" (Vance, 2015, p. 97). Further, Musk declared his intent to persevere (Musk-MD-02) despite repeated setbacks and advice from others to stop - "I will spend my last dollar on these companies" (Vance, 2015, p. 198) - and his resolution to maintain control of a privately-held SpaceX (Musk-MD-04) with no trading of shares on the public markets. The business ecosystems literature reviewed in section 2.2 previously argued that business ecosystems may be incompatible with strong control (q.v., Table 9 and subsection 2.3.4). Diamandis, in contrast, expressed no such desire for strong control, and favoured the business ecosystem organizational form.

The second explanation relates to the resources available to the entrepreneur for authoring. Branson and Musk both had abundant wealth available to launch their space ventures - Branson through control of the Virgin Group of Companies, and Musk through a personal fortune amassed from the acquisition of PayPal by eBay. Neither Branson nor Musk experienced the severe resource constraints that motivate many earlystage technology entrepreneurs to launch their start-ups within business ecosystems (Muegge, 2013; Bailetti \& Bot, 2013; Muegge \& Mezen, 2017). Diamandis, in contrast, 
needed help from others to open up space (Diamandis-A-02): going alone was never a viable option for Diamandis.

Furthermore, both explanations for the circumstances favouring more traditional organizational forms - the longing for control, and direct access to wealth - may be mutually reinforcing to reject ecosystems. Musk founded SpaceX with with \$100M of his own money; Vance (2015, p. 116) writes: "With such a massive up-front investment, no one would be able to wrestle control of SpaceX away from Musk as they had done at Zip2 and PayPal.”

The chapter has presented of the results of the thesis. The next chapter discusses these results. 
Emancipated entrepreneuring in the nascent commercial spaceflight industry:

Authoring ecosystems by Branson, Diamandis, and Musk. Copyright (C) 2018 Ewan Reid

\section{Discussion}

This chapter discusses the results that were reported in the previous chapter.

Section 5.1 presents the answer to the research question. Section 5.2 discusses the insights from the results and positions the insights with respect to the literature reviewed in chapter 2. Section 5.3 discusses the empirical support for connections between business ecosystems and emancipation. Section 5.4 reflects on the lessons learned by the author from completing this thesis. Section 5.5 discusses the contribution to research.

Section 5.6 discusses the contribution to practice. Section 5.7 addresses the limitations of this research. Section 5.8 proposes opportunities for future research.

\subsection{Answer to the research question}

The research question was the following: How do business ecosystems feature in the emancipatory actions of entrepreneurs in the commercial spaceflight industry?

Business ecosystems feature in the emancipatory actions of entrepreneurs in the commercial spaceflight industry in three ways: (1) as a means of seeking autonomy by breaking free of or breaking up perceived constraints, (2) in the authoring activities to realize change (including the work to create a new business ecosystem or to join, maintain, grow, or change an established ecosystem), and (3) in the making declarations activities to mobilize support, manage interpretations by stakeholders, and generate change effects in others. Markets, hierarchies, and business ecosystems all feature in emancipatory actions. Ecosystems may be more prominent when resources are more constrained, and when entrepreneurs are more willing to let go of absolute control, and 
less prominent when the entrepreneur has greater wealth and seeks greater control.

The extended discussion and background for this answer is comprised of six parts. Subsection 5.1.1 discusses the conceptual linkages between emancipation and business ecosystem constructs identified in chapter 2. Subsection 5.1.2 discusses the prevalence of the business ecosystem organizational form in the emancipatory actions of the three case entrepreneurs. Subsections 5.1.3, 5.1.4, and 5.1.5 each discuss the empirical evidence from the case results about how ecosystems feature in one of the three core elements of emancipation - seeking autonomy, authoring, and making declarations, respectively - and position the findings with respect to the literature. Subsection 5.1.6 discusses the tentative explanations developed in subsection 4.7.5 to explain why particular entrepreneurs made the choices they did regarding organizational forms.

\subsubsection{Conceptual links between ecosystems and emancipation}

Section 2.3 theorized about possible connections between the constructs of the business ecosystems literature (reviewed in section 2.2) and the three core elements of the emancipation perspective on entrepreneuring (reviewed in section 2.1).

Seeking autonomy is the impetus for entrepreneuring - the perceived need of the entrepreneur to break free of or break up perceived constraints (subsection 2.1.1). In the literature, business ecosystems can be a means of seeking autonomy from at least six types of perceived constraints: (1) poverty (Prahalad, 2005; Marti et al. 2013), (2) the inflexibility of integral, non-modular architectures (Baldwin \& Clark, 2000),

(3) excessive intellectual property rights that can limit innovation (Raymond, 2001;

Benkler, 2002; Lessig, 2004; Weber, 2004), (4) the limited resources, limited local reach, 
limited prior experience and limited access to partners of early-stage technology entrepreneurs (Bailetti, 2012; Muegge, 2013; Bailetti \& Bot, 2013; Muegge \& Mezen, 2017), (5) the limitations imposed by producer innovation (von Hippel, 2005; Baldwin \& von Hippel, 2011), and (6) an entrenched taken-for-granted value proposition reinforced by established structures (Adner, 2017).

Authoring is defining new resource arrangements, relationships, and rules of engagement - taking ownership to change positions of power, realize change-creating intent, and preserve and enhance emancipatory potential (subsection 2.1.2). Authoring thus includes the various structural work to create a new business ecosystem, or to join, maintain, grow, or change an established ecosystem, including choosing or changing roles (Iansiti \& Levien, 2004), attracting specialized complementors (Brandenburger \& Nalebuff, 1996), guiding the development of the core platform (Gawer, 2014; Gawer \& Cusumano, 2014; Thomas et al. 2014), and coordinating co-evolution of the network (Moore, 2006). According to Adner (2017), ecosystem structure is "alignment of activities, actors, positions, and links" (p. 40) - all four parts falling within the scope of authoring. Likewise, formulating an ecosystem strategy - "the way in which a focal firm approaches the alignment of partners and secures its role in a competitive ecosystem" (Adner, 2017, p. 47) - is partly an authoring activity.

Making declarations is about managing interpretations and expectations, mobilizing support, and generating change effects through discursive and rhetorical acts about intended change (subsection 2.1.3). Making declarations thus includes the various discursive and rhetorical work of business ecosystems: promoting ecosystem health 
(Iansiti \& Levien, 2004), building and maintaining consensus around shared purpose (Moore, 2013), channeling the creative energy of the community (Muegge, 2013), maintaining or changing the problem field of innovation (Baldwin \& von Hippel, 2011), positioning leaders and followers (Adner, 2017), and confronting any misalignment of partners in order to bring about partner alignment (Adner, 2017).

Thus all three core elements of the emancipation perspective of entrepreneuring seeking autonomy, authoring, and making declarations - are conceptually related to constructs and ideas associated with business ecosystems. Alternatively, subsection 2.3.4 argued that entrepreneurs seeking exclusive control and absolute autonomy may perceive business ecosystems as constraining rather than emancipating, and may be better suited to other organizational forms. These conceptual connections identified from the literature provide the basis for subsequent discussion in section 5.2 and section 5.3 of this chapter.

\subsubsection{Prevalence of the business ecosystem organizational form}

The cross-case results in section 4.7 demonstrated that all three of the Moore (2006) organizational forms - markets, hierarchies, and business ecosystems - do feature in emancipatory actions of entrepreneurs in the commercial spaceflight sector.

The business ecosystem was the favoured organizational form for the emancipatory actions of Peter Diamandis, founder of XPRIZE, driven "to help entrepreneurs create extraordinary wealth while creating a world of abundance" (Diamandis \& Kotler, 2015, p. 274) while breaking free of the constraints of government space agencies and over-reliance on motivation by extrinsic monetary rewards. 
The organizational hierarchy was the favoured form for the emancipatory actions

of Elon Musk, founder of SpaceX. Musk innovated in-house through vertical integration, relentlessly in-sourcing work previously accomplished through suppliers, and reducing dependence on others. This was consistent with Musk's version of seeking autonomy to maintain focus on bold long-term goals - including making humans an interplanetary species by establishing a sustainable human settlement on Mars.

Markets were the favoured form for the emancipatory actions of Richard Branson, founder of Virgin Galactic. Branson chose to license the core technologies for spaceflight, contract with suppliers for development and prototyping, and enter into a joint venture for production manufacturing. This was consistent with Branson's version of seeking autonomy to pursue what he found most exciting, fulfilling, and impactful.

\subsubsection{Authoring ecosystems}

Four authoring events were coded to the business ecosystem organizational form (subsection 4.7.4, Table 34) - the highest event count of the three emancipation elements.

"Incentive prizes to solve global challenges" (Diamandis-A-01) utilizes multiple forms of innovation including open innovation (Chesbrough, 2003), democratized innovation (von Hippel, 2005), and open collaborative innovation (Baldwin \& von Hippel, 2011). The change-creating intent was to motivate innovation in specific domains and high-impact problems, and the means was novel incentives: contests and innovation prizes as new rules of engagements. XPRIZE launched as the keystone (Iansiti \& Levien, 2004) and leader (Adner, 2017) of this new ecosystem. 
"Launch and grow space companies" (Diamandis-A-02) mobilized help from others by building mutually-beneficial relationships with complementors (Brandenburger $\&$ Nalebuff, 1996; Moore, 1999), appealing to shared purpose (Moore, 2013), and utilizing "the same economic engine that had opened every previous frontier" (Diamandis \& Kotler, 2015, p. 97). Ecosystems as a means of getting help to achieve big objectives in commercial spaceflight is consistent with ecosystems as a partial remedy to the problems of early-stage entrepreneurs in the technology entrepreneurship literature (Muegge, 2013; Bailetti \& Bot, 2013), and as the setting for collaborative innovation (Baldwin \& von Hippel, 2011) and innovation around platforms (Gawer \& Cusumano, 2014). The ecosystem is emancipating for the entrepreneur and his space companies.

"Enable others to solve big problems" (Diamandis-A-03) is about fostering ecosystems that are emancipating for others - by disseminating knowledge, creating support systems, and enabling connections to help others achieve, similar to the systems for venture creation described by Bailetti \& Bot (2013) and Muegge \& Mezen (2017).

"Join the network" (Musk-A-01) was about Musk's entry to the space industry joining the established network. Prior to SpaceX, Musk was an outsider to the space industry. His previous successes had been in the information technology and online payment sectors. Founding a space company required building connections, trust, and legitimacy with rocket scientists and other specialists - key resource providers with highly specialized skills in the relatively small, tight-knit space community.

Consistent with the conceptual argument developed in subsection 2.3.2 and discussed in subsection 5.1.1, the four ecosystem authoring events from the case results 
demonstrate how the structural work to create, maintain, grow and join ecosystems can be emancipating. The new organizational arrangements include all four components of ecosystem structure (Adner, 2017): activities, actors, positions, and links.

\subsubsection{Seeking autonomy with ecosystems}

One seeking autonomy event was coded to the business ecosystem organizational form (subsection 4.7.4, Table 33).

The event "NASA cannot get me to space" (Diamandis-SA-01) follows from frustration with the limitations of public-sector government space agencies: "Constrained by government spending and frightened by the risk of failure, [NASA] had become a military-industrial jobs program unlikely to return to the Moon or push onward to Mars" (Diamandis \& Kotler, 2015, p. 96). The entrenched value proposition (Adner, 2017) and associated value network of government space agencies had become a constraint that blocked progress; this value proposition was reinforced by integral architecture (Baldwin \& Clark, 2000) and monetary incentives around traditional IP (Benkler, 2002; Lessig, 2004) and producer innovation (Baldwin \& von Hippel, 2011), and Diamandis faced the typical limitations of an early-stage technology entrepreneur (Muegge, 2013).

Envisioning a bold future free of these constraints, with private commercial spaceflight, return to the moon, and travel to Mars, Diamandis founded new organizations linking people interested in space, founded private space ventures without government help, and launched XPRIZE to stimulate innovation in new ways. Consistent with the conceptual argument developed in subsection 2.3.1 and discussed in subsection 5.1.1, business ecosystems and related ideas were the means of escaping perceived constraints. 


\subsubsection{Declaring ecosystems}

One making declarations event was coded to the business ecosystem organizational form (subsection 4.7.4, Table 35).

The event "future of abundance" (Diamandis-MD-02) conveyed the Diamandis vision of the future in discursive and rhetorical forms intended to manage interpretations, mobilize support, and motivate action. Contestations that linear technologies progress slowly and incrementally are overcome by assertions of exponential growth: "Exponential technology is not just putting linear companies out of business, it's also putting linear industries out of business" (Diamandis \& Kotler, 2015, p. 17).

Diamandis sought to channel the energy of a community towards useful endeavours (von Hippel, 2005; Baldwin \& von Hippel, 2011; Muegge, 2013), position his organizations in places of leadership and influence, demonstrate thought leadership, establish expectations around a problem field utilizing bold thinking, and convince others to step up to leadership roles in niches. Consistent with the conceptual argument developed in subsection 2.3.3 and discussed in subsection 5.1.1, the discursive and rhetorical work of business ecosystems can be emancipating.

\subsubsection{Selection of the business ecosystems organizational form}

Subsection 4.7.5 proposed two tentative explanations, induced from the case results, for why an entrepreneur may favour the business ecosystem organizational form for their emancipatory actions. First, it proposed that ecosystems are more appealing for entrepreneurs willing to collaborate and share control, and less appealing for entrepreneurs craving absolute control. Second, it proposed that ecosystems are more 
appealing for entrepreneurs facing resource constraints for whom vertically-integrated hierarchies and contracting the required goods and services in the market are unattainable, and less appealing for entrepreneurs with abundant wealth for whom traditional forms are viable.

In the case results reported in subsection 4.7.4 and discussed in subsection 5.1.2, Diamandis favoured business ecosystems for emancipatory actions. Facing the problems of limited resources and limited access to partners typical of early-stage technology entrepreneurs (Muegge, 2013), Diamandis founded new keystones organizations (Iansiti \& Levien, 2004), nurtured ecosystems anchored around shared purpose (Moore, 2013), enabled collaborative innovation (Baldwin \& von Hippel, 2011), and launched privatelyfunded space startups addressing specialized niches.

Branson, with control of the Virgin Group of Companies and declarations to maintain the full control of Virgin Galactic, favoured the market form.

Musk, with a personal fortune from the acquisition of PayPal and a high need for control, favoured the vertically-integrated organizational hierarchy.

These propositions are internally-consistent to explain the case results but have not been validated with other entrepreneurs or other industry sectors.

\subsection{Insights}

There are at least three insights from the results of this thesis: (1) business ecosystems can and do feature in emancipation, most strongly evident in the authoring core element of the emancipation perspective but also evident in the seeking autonomy and making declarations elements, (2) the emancipation potential of business ecosystems 
may depend on circumstances, with ecosystems least emancipating for entrepreneurs with abundant wealth and high need for control, and (3) support for the Rindova et al. (2009) assertion that social entrepreneurship is not distinct from entrepreneurship.

The first insight is that business ecosystems were most strongly evident in authoring events and less evident in seeking autonomy and making declarations events. If ecosystem structure is "alignment of of activities, actors, positions, and links" (Adner, 2017, p. 40), then the work to build, maintain, or change this structure is authoring in the emancipation perspective: taking ownership by defining relationships, arrangements, and rules of engagement, and changing the positions of power (Rindova et al. 2009). The ecosystem authoring events observed in this thesis included forming entirely new ecosystems (Diamandis-A-01), joining and shaping ecosystems to be emancipating for the entrepreneur (Musk-A-01; Diamandis-A-02), and launching and maintaining ecosystems to be emancipating for others (Diamandis-A-03). Business ecosystems also feature in seeking autonomy as a means of escaping constraints (Diamandis-SA-01) and in making declarations to manage expectations, mobilize support, and motivate action (Diamandis-MD-02), but less frequently than in authoring.

The second insight is that the potential for business ecosystems to be emancipating is circumstance-contingent, likely dependent on both the entrepreneur and the environment. More specifically, business ecosystems may be least emancipating for entrepreneurs with high need for control and direct control of abundant wealth. In the technical language of the emancipation perspective, the relevant circumstances are the nature of the perceived constraints and the change-creating intent of the entrepreneur, and 
the resources available for authoring. For Diamandis, markets and hierarchies were not viable - an alternative approach was needed. For Branson and Musk, traditional organizational forms were viable and also better suited to their desires for control. The arguments here about viablility of different organizational forms under different circumstances are similar to those of Baldwin \& von Hippel (2011) about viability of different forms of innovation, but at a much earlier stage of theorizing and formalization.

The third insight is support for the Rindova et al. (2009) assertion that the emancipation perspective "challenges the extant distinction between 'regular' (for profit) and social (not-for-profit) entrepreneurship" (p. 479). Researchers of social entrepreneurship phenomena, who often describe their domain as distinct from mainstream entrepreneurship and thus requiring different theories, have been active consumers and adopters of the emancipation perspective. Social entrepreneurship was a recurring theme in research articles utilizing the emancipation perspective reviewed in section 2.1 (Table 6 and Table 7). However, Rindova et al. (2009) had previously argued that "implied opposition between emancipatory projects to create change and a 'hardnosed business strategy' is a false one" (p. 483). According to Rindova, the common practice of treating social entrepreneurship as somehow different from entrepreneurship is "detrimental" (p. 483) because many profitable ventures were inspired by dreaming up new worlds, and many social change efforts have profit potential. All three of the entrepreneurs examined here in this thesis claimed motivations other than profit. Branson wrote: "If you aren't making a positive difference to other people's lives, then you shouldn't be in business" (Branson, 2015, p. 375). Diamandis wrote: “Autonomy is 
the desire to steer our own ship. Mastery is the desire to steer it well. And purpose is the need for the journey to mean something. These three intrinsic rewards are the very motivators that motivate us most" (Diamandis \& Kotler, 2015, p. 79). Vance (2015, p. 17) wrote: "Musk wants to ... save the human race from self-imposed or accidental annihilation." Diamandis explicitly declared that "World's biggest problems=biggest business opportunities" (Diamandis \& Kotler, 2015, p. xii), and supported his argument with explanations of bold thinking from both Branson and Musk. He made explicit his own massively transformative purpose: "To help entrepreneurs create extraordinary wealth while creating a world of abundance" (p. 274). All three case entrepreneurs in this thesis sought both profits and social outcomes, and the emancipation perspective addressed all of these aspects of entrepreneuring, profit and social, equally well within the same framework.

In addition to rejecting the "special status" of social entrepreneurship, these results may also suggest some new and different questions about the sequencing, prioritization, and interaction of motivations and outcomes, and of ends vs. means. For example, the three entrepreneurs appear to differ in the relative timing of profits and social change. Branson builds profitable businesses that make a positive difference to people's lives (Branson-SA-01; Branson-A-03). Musk, since the acquisition of PayPal in 2002, builds profitable businesses as a way to pursue ambitious goals (Musk-A-02; Musk-A-07) - most remarkably "turning humans into an interplanetary species" (Vance, 2015, p. 331). Diamandis urges bold entrepreneurs to pursue profits and social change together. How these differences impact entrepreneuring is a topic for future research. 


\subsection{Empirical support for connecting ecosystems and emancipation}

Section 2.3 theorized about conceptual connections between business ecosystems and the core elements of the emancipation perspective, and subsection 5.1.1 discussed these connections as a partial answer to the research question. This thesis contributes new empirical evidence about three aspects of these connections: (1) the constraints which can be broken free from or broken up by ecosystems, (2) the new arrangements defined by authoring ecosystems, and (3) making declarations about intended change.

The first aspect of empirical support is about the constraints for which business ecosystems can be a means of escape. Subsections 2.3.1 and 5.1.1 previously identified six types of constraints from the business ecosystem literature, and subsection 5.1.4 reported empirical evidence for ecosystems as means of escape from five of the six types: (1) inflexible architectures, (2) IP arrangements that limit innovation, (3) the resource and process limitations of early-state technology entrepreneurs, (4) the limits imposed by producer innovation, and (5) entrenched value propositions. There was no direct empirical support for escape from poverty - a common theme in both the emancipation and business ecosystems literatures. Six of the seven empirical articles utilizing the emancipation perspective (summarized in Table 7 in subsection 2.1.5) had touched on the constraints imposed by poverty; likewise "serving the world's materially poorest citizens" at "the bottom of the pyramid" had been the motivation for the Prahalad (2005) ecosystem. Although the emancipatory actions of entrepreneurs in the commercial spaceflight industry were not directly related to poverty reduction, Diamandis explicitly situated his spaceflight efforts within the higher level abstractions of abundance - the 
future is better than we think - and bold - going big, creating wealth, and impacting the world, and his authoring actions enabling others to solve big problems (Diamandis-A03), declarations about the future of abundance (Diamandis-MD-02), and declarations about bold entrepreneurs solving problems and creating wealth (Diamandis-MD-03). Diamandis \& Kotler (2015, p. xi) write:

What I witnessed from the helm of [XPRIZE and Singularity University] was a world where the basic necessities of life were becoming cheaper and globally accessible... Emerging forces ... give us the ability to solve many of the world's grandest challenges over the next two to three decades. That is, we will soon have the power to meet and exceed the basic needs of every man, woman, and child on the planet.

Paraphrasing Diamandis in the language of the literature, the bold thinking that underpins emancipatory actions to realize commercial spaceflight is the same thinking needed to realize a world of abundance where everyone's basic needs are met. If so, findings here may be of great relevance also to scholars and practitioners pursing poverty reduction.

The second aspect of empirical support for connections is the new arrangements defined by authoring ecosystems. Subsections 2.3.2 and 5.1.1 previously reported four examples from the prior literature of the structural work of business ecosystems. Subsection 5.1.3 reported direct empirical evidence for all four arrangement types: (1) relationships with other ecosystem members, (2) roles and arrangements to preserve emancipatory potential, (3) the rules of engagement with ecosystem members and ecosystem resources that reflect change-creating intent, and (4) shifts in ecosystem structure that change positions of power. For example, Diamandis launched XPRIZE as the keystone (Iansiti \& Levien, 2004) and leader (Adner, 2017) of a new ecosystem 
which shifted power away from traditional incumbents, defined new relationships with key resources providers including new funders that were external to the status quo system, and preserved emancipatory potential for a future series of innovation prizes that is still ongoing. The contest rules for the various XPRIZE competitions were quite literally new rules of engagement.

The third and final aspect is about making declarations about intended change. Subsections 2.3.3 and 5.1.1 previously reported six examples from the prior literature of the discursive and rhetorical work of business ecosystems. Subsection 5.1.5 reported direct empirical evidence for five of the six: (1) building and maintaining consensus around shared purpose, (2) channelling the creative energy of the community, (3) maintaining or changing the problem field of innovation, (4) positioning leaders and followers, and (5) confronting any misalignment of partners in order to bring about partner alignment. Interestingly, there was no direct empirical support for declarations promoting ecosystem health in the case data.

\subsection{Lessons learned from writing this thesis}

The process of completing this thesis document and the associated research afforded me the opportunity to learn several new skills and recognize lessons. The five most-valued lessons are described in this section.

First, I completed the largest and most thorough literature review in my academic and professional career to date. This afforded me the opportunity to learn how to conduct a thorough literature review and the value of doing so.

Second, I was exposed to NVivo for the first time and learned how it can be used 
compile coded text from a variety of sources in a convenient way. I also confronted the limitations of Nvivo, including the lack of features to assign text-based properties to a "case node", therefore requiring a linked memo. I learned how to code source material for subsequent analysis in a systematic and rigorous way.

Third, the rigorous review of the commercial spaceflight industry from an academic perspective provided me with new insight into the industry that I know very well as an engineer and entrepreneur. The capability to re-examine a familiar setting through a lens of management theory is something I will continue to use in my career.

Fourth, when starting the review of the primary sources, it proved very valuable to have taken detailed notes during the first readings of each of them. In subsequent reviews and during the coding process, this preliminary set of notes became the baseline for the coding pilots and the subsequent incident and event coding. The analysis was streamlined because of this early and reasonably comprehensive set of notes. Thus I learned the value of comprehensive note-taking and maintaining chains of evidence.

Fifth, it was very heartening to observe some of the results related to motivations and approaches for companies in the commercial spaceflight industry. Fun as a motivator for the selection of business opportunities, pursuing impactful and bold objectives, and implementing a start-up approach to space are all things I strive for as I continue to lead and grow the commercial space company that I founded at the outset of this work. 


\subsection{Contribution to research}

This thesis makes two contributions to management research.

First, it contributes a new operational specification for an event study using the emancipation perspective on entrepreneuring. An extensive literature review identified no prior research that operationalized the Rindova et al. (2009) emancipation constructs in a form that was appropriate for an event study. Therefore, this thesis developed a new event study operational specification presented in its complete form in chapter 8 (Appendix: Operational specification ). Other researchers can employ this specification to replicate these results, extend the data set reported here, and to study the emancipatory actions of technology entrepreneurs in other domains. We look forward to validating the specification in new field settings.

Second, it joins two previously distinct domains - emancipation perspective of entrepreneuring and business ecosystems - opening up new research opportunities in both. Theoretically and empirically, business ecosystems feature in all three core elements of emancipation: (1) as a means of seeking autonomy by escaping perceived constraints, (2) in the authoring activities to realize change (the structural work to create a new business ecosystem or to join, maintain, grow, or change an established ecosystem), and (3) in the making declarations activities to mobilize support, manage interpretations by stakeholders, and generate change effects in others (the discursive and rhetorical work of business ecosystems). Business ecosystems can be emancipating, particularly for entrepreneurs facing resource constraints for whom traditional hierarchies and market structures are infeasible, and who are willing to collaborate and share control. 
Conversely, entrepreneurs endowed with significant wealth and demanding absolute control may find ecosystems constraining.

\subsection{Contribution to practice}

This thesis also contributes to management practice. The formal specification of emancipatory actions by Sir Richard Branson, Peter Diamandis, and Elon Musk will be of interest to ambitious technology entrepreneurs seeking ideas, inspiration, and insights for their own emancipatory endeavours. All three case entrepreneurs successfully sought autonomy by escaping perceived constraints, authored new rules of engagement and organizational arrangements to bring about change, and made declarations to mobilize support. Peter Diamandis made extensive use of business ecosystem structures and collaborative innovation to enact change; like many early-stage technology entrepreneurs with ambitious dreams, neither vertical integration nor paying others for services in the marketplace were feasible approaches. Diamandis was willing to motivate and enable others. Richard Branson and Elon Musk had both amassed significant wealth from prior successes, and demanded direct personal control of their companies. Both choose more traditional organizational structures for their space ventures: Branson licensed the core technologies, contracted with suppliers for development and prototyping, and entered into joint ventures manufacturing and operations, and Musk invested his own personal wealth to innovate in-house through vertical integration, relentlessly in-source work by suppliers, and reduce dependence on others. Despite different approaches to organization, all three entrepreneurs sought for and achieved both profits and social outcomes. 


\subsection{Limitations}

All research has limitations; this section describes four limitations of this study.

First, this thesis examined a subset of entrepreneurs in commercial spaceflight and their associated space companies. Other entrepreneurs and ventures were excluded. For example, there are NewSpace ventures attempting to leverage increases in computing power and other technological advancements to design, build, and launch constellations of small satellites to perform various Earth observation and telecommunications functions. These ventures, along with many other ventures pursuing novel business opportunities in space, were outside the scope of this thesis. It may be that business ecosystems feature differently in the emancipatory actions of other entrepreneurs leading other NewSpace ventures.

Second, this thesis did not study the differentiating characteristics of the NewSpace sector. NewSpace may differ in significant ways from more conventional industry sectors, and if so, those differences were outside the scope of this study. The extent to which these results generalize to other sectors is an empirical question requiring further research.

Third, this thesis did not include any quantitative assessment of the entrepreneurs or their companies, nor did it collect primary data (for example, there were no interviews). The sources were published books which did differ from one another in style and scope. Two of these books were autobiographical works authored or coauthored by the entrepreneur, and one was a biographical work authored by a business columnist with access to the entrepreneur. The event study operational specification 
makes full use of these sources, but it cannot assess the impact (if any) of these differences. Other research employing the emancipation perspective, including the seminal article (Rindova et al. 2009), often shares this limitation.

Fourth, the operational specification for an event study using the emancipation perspective on entrepreneuring is a new contribution employed here for the first time. It has not yet been validated in other studies.

\subsection{Future research}

There are at least four opportunities for new research following from this thesis.

First, future research should extend the data set to include more entrepreneurs and greater diversity of commercial space opportunities - for example, asteroid and lunar mining, earth observation with small satellites, and communications with small satellites.

Second, researcher should revisit these entrepreneurs and their commercial space ventures periodically in the future to extend the event timelines and to re-examine the events of this study. New sources (in addition to the three books employed here) could enrich the data set with additional perspectives and enable triangulation.

Third, future research should apply the event study approach to entrepreneuring as emancipation in other industry sectors. Replication of the method is needed to assess external validity of these results and to validate the operational specification.

Fourth, future research could examine the sequencing, prioritization, and interaction of motivations and outcomes suggested in section 5.2.

This chapter has discussed the results reported in the previous chapter. The next and final chapter concludes the thesis.

\section{Copyright (C) 2018 Ewan Reid}


Emancipated entrepreneuring in the nascent commercial spaceflight industry:

Authoring ecosystems by Branson, Diamandis, and Musk. Copyright (C) 2018 Ewan Reid

\section{Conclusion}

This thesis examined how business ecosystems feature in the emancipation actions of entrepreneurs in the nascent commercial spaceflight industry. The research method was an event study of three entrepreneurs and their commercial spaceflight ventures: Sir Richard Branson and Virgin Galactic, Peter Diamandis and XPRIZE, and Elon Musk and SpaceX. Results demonstrated that all three of the Moore (2006) organizational forms - markets, hierarchies, and business ecosystems - can and do feature in emancipatory actions. Business ecosystems can be a means of seeking autonomy to escape constraints. Authoring activities can grow new ecosystems or join, maintain, grow, or change existing ecosystems. Making declarations activities can mobilize support, manage interpretations, and generate change effects in others. Contributions to theory and practice include an operational specification for an event study using the emancipation perspective on entrepreneuring, the joining of two literatures that were previously distinct, and formal specification of the emancipatory actions by Branson, Diamandis, and Musk. Future researchers can replicate the event study research design in other industry sectors, and extend the data set to more entrepreneurs and more ventures within the NewSpace industry segment.

The entrepreneurs examined here espoused diverse motivations for change and enacted change through a broad range of tactics and organizational forms. The emancipation perspective effectively accommodated all these aspects of entrepreneuring in one framework - an appealing feature for future technology entrepreneurship research. 
Emancipated entrepreneuring in the nascent commercial spaceflight industry:

Authoring ecosystems by Branson, Diamandis, and Musk. Copyright (C) 2018 Ewan Reid

\section{References}

Abbott, A. 1984. Event sequence and event duration: colligation and measurement. Historical Methods, 17: 192-204.

Adams, M., \& Makramalla, M. 2015. Cybersecurity skills training: An attacker-centric gamified approach. Technology Innovation Management Review, 5(1): 5-14. http://timreview.ca/article/861

Adner, R. 2017. Ecosystem as structure: An actionable construct for strategy. Journal of Management, 43(1): 39-58.

Ahl, H., \& Nelson, T. 2015. How policy positions women entrepreneurs: A comparative analysis of state discourse in Sweden and the United States. Journal Of Business Venturing, 30(2): 273-291.

Bailetti, T. 2012. What technology startups must get right to globalize early and rapidly. Technology Innovation Management Review, 2(10): 5-16. http://timreview.ca/article/614

Bailetti, T., \& Bot, S. D. 2013. An ecosystem-based job-creation engine fuelled by technology entrepreneurs. Technology Innovation Management Review, 3(2): 31-40. http://timreview.ca/article/658

Baker, T., \& Nelson, R. E. 2005. Creating something from nothing: Resource construction through entrepreneurial bricolage. Administrative Science Quarterly, 50: 329- 366.

Baldacchino, L., Ucbasaran, D., Cabantous, L., \& Lockett, A. 2015. Entrepreneurship research on intuition: A critical analysis and research agenda. International Journal Of Management Reviews, 17(2): 212-231.

Baldwin, C. Y. \& Clark, K. B. 2000. Design Rules: Volume 1: The Power of Modularity. MIT Press, Cambridge.

Baldwin, C. Y. and Clark, K. B. 2006. The architecture of participation: does code architecture mitigate free riding in the open source development mode? Management Science. 52(7): 1116-1127.

Baldwin, C. Y., \& von Hippel, E. 2011. Modeling a paradigm shift: From producer innovation to user and open collaborative innovation. Organization Science, 22(6): 1399-1417.

Baron, R. A., Franklin, R. J., \& Hmieleski, K. M. 2016. Why entrepreneurs often experience low, not high, levels of stress. Journal Of Management, 42(3): 742768 . 
Baron, R., Zhao, H., \& Miao, Q. 2015. Personal motives, moral disengagement, and unethical decisions by entrepreneurs: Cognitive mechanisms on the 'slippery slope'. Journal Of Business Ethics, 128(1): 107-118.

Bazeley, P., \& Jackson, K. 2013. Qualitative data analysis with NVivo, 2nd edition. Sage.

Belfiore, M. 2007. Chapter 7: Orbit on a Shoestring. Rocketeers. Harper Collins. pp. 166-95.

Benkler, Y. 2002. Coase's penguin, or, Linux and The Nature of the Firm. Yale Law Journal, 112(3): 369-446.

Bissola, R., Imperatori, B., \& Colonel, R. T. 2014. Enhancing the creative performance of new product teams: An organizational configurational approach. Journal Of Product Innovation Management, 31(2): 375-391.

Blatt, R. 2009. Tough love: How communal schemas and contracting practices build relational capital in entrepreneurial teams. Academy Of Management Review, 34(3): 533-551.

Brandenburger, A. M. \& Nalebuff, B. J. 1996. Co-opetition, HarperCollins Business, New York.

Brandt, R. L. One click: Jeff Bezos and the rise of Amazon.com. New York, NY: Portfolio/Penguin.

Branson, R. 2015. The Virgin Way: If it's not fun, it's not worth doing, Reprint Edition. New York, NY: Portfolio/Penguin.

Branzei, O., \& Abdelnour, S. 2010. Another day, another dollar: Enterprise resilience under terrorism in developing countries. Journal Of International Business Studies, 41(5): 804-825.

Bruton, G. D., Ketchen, D. J., \& Ireland, R. D. 2013. Entrepreneurship as a solution to poverty. Journal Of Business Venturing, 28(6): 683-689.

Bullough, A. 2013. Perceptions of women entrepreneurs in male-dominated leadership cultures: More positive support for women than many thought. Journal of Enterprising Culture, 21(3): 359-374.

Burg, E., \& Romme, A. L. 2014. Creating the future together: Toward a framework for research synthesis in entrepreneurship. Entrepreneurship: Theory \& Practice, 38(2): 369-397.

Busenitz, L. W., Plummer, L. A., Klotz, A. C., Shahzad, A., \& Rhoads, K. 2014. Entrepreneurship research (1985-2009) and the emergence of opportunities. Entrepreneurship: Theory \& Practice: 981-1000. 
Calás, M. B., Smircich, L., \& Bourne, K. A. 2009. Extending the boundaries: Reframing "Entrepreneurship as social change" through feminist perspectives. Academy $\boldsymbol{O} \boldsymbol{f}$ Management Review, 34(3), 552-569.

Cardon, M. S., Wincent, J., Singh, J., \& Dronvsek, M. 2009. The nature and experience of entrepreneurial passion. Academy Of Management Review, 34(3): 511-532.

Caulfield, B. 2012. Peter Diamandis: Rocket Man. Forbes. Archived from the original on July 16, 2012. Retrieved September 2, 2017.

Chandler, A. D. 1977. The visible hand: The managerial revolution in American business. Cambridge, MA: Harvard University Press.

Chang, K. 2012. First private craft docks with space station. New York Times, May 26. http://www.nytimes.com/2012/05/26/science/space/space-X-capsule-docks-atspace-station.html

Chesbrough, H. W. 2003. Open innovation: The new imperative for creating and profiting from technology. Harvard Business School Press, Boston.

Coase, R. 1937. The nature of the firm. Economica. 4:386-405.

Collins, R. 2004. Interaction ritual chains. Princeton: Princeton University Press.

Courpasson, D., Dany, F., \& Martí, I. 2016. Organizational entrepreneurship as active resistance: A struggle against outsourcing. Entrepreneurship: Theory \& Practice, 40(1): 131-160.

Dey, P., \& Steyaert, C. 2016. Rethinking the space of ethics in social entrepreneurship: Power, subjectivity, and practices of freedom. Journal Of Business Ethics, 133(4): 627-641.

Diamandis, P. H. 2017. http://www.diamandis.com/about. Retrieved September 3, 2017

Diamandis, P. H. 2012. Abundance is our future. TED2012 (February). Available online: https://www.ted.com/talks/peter_diamandis_abundance_is_our_future

Diamandis, P. H., \& Kotler, S. 2012. Abundance: The future is better than you think. New York: Simon \& Schuster.

Diamandis, P. H., \& Kotler, S. 2015. Bold: How to go big, create wealth, and impact the world. New York: Simon \& Schuster.

Doern, R., \& Goss, D. 2013. From barriers to barring: Why emotion matters for entrepreneurial development. International Small Business Journal, 31(5): 496519.

Eisenhardt, K. M. 1989. Building theories from case study research. Academy of Management Review, 14(4): 532-550. 
Eisenhardt, K. M., \& Graebner, M. E. 2007. Theory building from case studies: opportunities and challenges. Academy of Management Journal, 50(1): 25-32.

Eisenhardt, K. M., Graebner, M. E., \& Sonenshein, S. 2016. Grand challenges and inductive methods: Rigor without rigor mortis. Academy of Management Journal, 59(4): 1113-1123.

Forbes. 2017. Richard Branson. Forbes.com. Retrieved September 3, 2017

Gawer, A. 2014. Bridging differing perspectives on technological platforms: Toward an integrative framework. Research Policy, 43(7): 1239-1249.

Gawer, A., \& Cusumano, M. A. 2014. Industry platforms and ecosystem innovation. Journal Of Product Innovation Management, 31(3): 417-433.

Goss, D., Jones, R., Betta, M., \& Latham, J. 2011. Power as practice: A microsociological analysis of the dynamics of emancipatory entrepreneurship. Organization Studies, 32(2): 211-229.

Gupta, V. K., Goktan, A. B., \& Gunay, G. 2014. Gender differences in evaluation of new business opportunity: A stereotype threat perspective. Journal Of Business Venturing, 29(2): 273-288.

Haugh, H., \& Talwar, A. 2016. Linking social entrepreneurship and social change: The mediating role of empowerment. Journal Of Business Ethics, 133(4): 643-658.

Hermes, J. S., \& Mainela, T. 2014. Mobilizing crisis management networks Entrepreneurial behavior in turbulent contexts. Industrial Marketing Management, 43(6): 967-976.

Huault, I., Perret, V., \& Spicer, A. 2014. Beyond macro- and micro- emancipation: Rethinking emancipation in organization studies. Organization, 21(1): 22-49.

Hudson, D. 2012. Entrepreneurial effort in the theory of the firm. Technology Innovation Management Review, 2(2): 13-16. http://timreview.ca/article/521

Hughes, K. D., Jennings, J. E., Brush, C., Carter, S., \& Welter, F. 2012. Extending women's entrepreneurship research in new directions. Entrepreneurship: Theory \& Practice, 36(3): 429-442.

Iansiti, M. \& Levien, R. 2004. Strategy as ecology. Harvard Business Review, 82(3): 6878.

Jennings, J. E., Jennings, P. D., \& Sharifian, M. 2016. Living the dream? Assessing the "Entrepreneurship as Emancipation" perspective in a developed region.

Entrepreneurship Theory and Practice., 40(1): 81-110. 
King, B. G., \& Pearce, N. A. 2010. The contentiousness of markets: Politics, social movements, and institutional change in markets. Annual Review Of Sociology, 36249-267.

Kisfalvi, V., \& Maguire, S. 2011. On the nature of institutional entrepreneurs: Insights from the life of Rachel Carson. Journal Of Management Inquiry, 20(2: 152-177.

Klotz, I. 2013. Profile: Sir Richard Branson, Founder, Virgin Galactic. Space News. Retrieved September 4, 2017.

Koçak, A., Morris, M. H., Buttar, H. M., \& Cifci, S. 2010. Entrepreneurial exit and reentry: An exploratory study of Turkish entrepreneurs. Journal $\boldsymbol{O} \boldsymbol{f}$

Developmental Entrepreneurship, 15(4): 439-459.

Lessig, L. 2000. Code and other laws of cyberspace. New York, NY: Basic Books.

Levie, J., \& Lichtenstein, B. B. 2010. A Terminal Assessment of Stages Theory: Introducing a Dynamic States Approach to Entrepreneurship. Entrepreneurship: Theory \& Practice, 34(2): 317-350.

Mainela, T., Puhakka, V., \& Servais, P. 2014. The concept of international opportunity in international entrepreneurship: A review and a research Agenda. International Journal Of Management Reviews, 16(1): 105-129.

Mair, J., Battilana, J., \& Cardenas, J. 2012. Organizing for society: A typology of social entrepreneuring models. Journal Of Business Ethics, 111(3): 353-373.

Marlow, S., \& Swail, J. 2014. Gender, risk and finance: why can't a woman be more like a man?. Entrepreneurship \& Regional Development, 26(1/2): 80-96.

Marti, I., Courpasson, D., \& Dubard Barbosa, S. 2013. "Living in the fishbowl". Generating an entrepreneurial culture in a local community in Argentina. Journal Of Business Venturing, 28(1): 10-29.

Marti, I., Courpasson, D., \& Dubard Barbosa, S. 2013. "Living in the fishbowl". Generating an entrepreneurial culture in a local community in Argentina. Journal Of Business Venturing, 28(1): 10-29.

Martí, I., \& Fernández, P. 2015. Entrepreneurship, togetherness, and emotions: A look at (postcrisis?) Spain. Journal Of Management Inquiry, 24(4): 424-428.

Martin, G. 2014. NewSpace: The "emerging" commercial space industry. https://ntrs.nasa.gov/archive/nasa/casi.ntrs.nasa.gov/20140011156.pdf, retrieved 2017-09-04.

McMullen, J. S., \& Warnick, B. J. 2016. Should we require every new venture to be a hybrid organization? Journal Of Management Studies, 53(4): 630-662. 
Miles, M. B. \& Huberman, A. M. 1994. Qualitative data analysis: An expanded sourcebook. London: Sage Publications.

Miron, W., \& Hudson, D. 2014. Enabling employee entrepreneurship in large technology firms. Technology Innovation Management Review, 4(2): 23-32. http://timreview.ca/article/766

Mitchell, R. K. 2011. Increasing returns and the domain of entrepreneurship research. Entrepreneurship: Theory \& Practice, 35(4): 615-629.

Moore, G. A. 1999. Crossing the chasm: Marketing and selling high-tech products to mainstream customers, Revised Edition. New York, NY: Harper Business.

Moore, J. F. 1993. Predators and prey: a new ecology of competition. Harvard Business Review, May/June: 75-86.

Moore, J. F. 1996. The death of competition. New York, NY: HarperBusiness.

Moore, J. F. 1998. The rise of a new corporate form. Washington Quarterly. 21(1): 167181.

Moore, J. F. 2006. Business ecosystems and the view from the firm. The Antitrust Bulletin, 51(1): $31-75$.

Moore, J. F. 2013. Shared purpose: A thousand business ecosystems, a connected community, and the future. CreateSpace Independent Publishing Platform.

Muegge, S. M. 2011a. Institutions of participation: A nested case study of company participation in the Eclipse Foundation, community, and business ecosystem. Doctoral thesis, Sprott School of Business, Carleton University. https://curve.carleton.ca/theses/31185

Muegge, S. M. 2011b. Business ecosystems as institutions of participation: A systems perspective on community-developed platforms. Technology Innovation Management Review, 1(2): 4-13. https://timreview.ca/article/495

Muegge, S. M. 2013. Platforms, communities, and business ecosystems: Lessons learned about technology entrepreneurship in an interconnected world. Technology Innovation Management Review, 3(2): 5-15. https://timreview.ca/article/655

Muegge, S. M., \& Mezen, M. 2017. Business ecosystems and new venture business models: An exploratory study of participation in the Lead to Win job-creation engine. International Journal of Technology Management, 75(1/2/3/4): 157192. 
Pattie, M., Parks, L., \& Wales, W. 2012. Who needs security? Entrepreneurial minorities, security values, and firm performance. Journal Of Management Inquiry, 21(3): 319-328.

Payette, J. 2014. Resolving legitimacy deficits in technology startups through professional services practices. Technology Innovation Management Review, 4(6): 22-17. http://timreview.ca/article/801

Pless, N., \& Appel, J. 2012. In pursuit of dignity and social justice: Changing lives through 100\% inclusion-How Gram Vikas Fosters Sustainable Rural Development. Journal Of Business Ethics, 111(3): 389-411.

Poole, M. S., Van de Ven, A. H., Dooley, K. J., \& Holmes, M. 2000. Organizational change and innovation processes: Theory and methods for research. New York, NY: Oxford University Press.

Prahalad, C. K. 2005. The fortune at the bottom of the pyramid: Eradicating poverty through profits. Wharton School Publishing: Upper Saddle River, NJ.

Raymond, E. S. 2001. The cathedral \& the bazaar: musings on Linux and open source by an accidental revolutionary. Sebastopol, CA: O'Reilly Media.

Reid, E., \& Muegge, S. M. 2014. Lean product development in the commercial space era. Poster presentation at the 65th International Astronautical Congress (IAC, September 29-October 3, Toronto, Canada).

Rindova, V., Barry, D., \& Ketchen, J. J. 2009. Entrepreneuring as emancipation. Academy Of Management Review, 34(3): 477-491.

Ritala, P., Heiman, B., \& Hurmelinna-Laukkanen, P. 2016. The need for speed-unfamiliar problems, capability rigidity, and ad hoc processes in organizations. Industrial \& Corporate Change, 25(5): 757-777.

Scott, L., Dolan, C., Johnstone-Louis, M., Sugden, K., \& Wu, M. 2012. Enterprise and inequality: A study of Avon in South Africa. Entrepreneurship: Theory \& Practice, 36(3): 543-568.

Scott, W.R. \& Davis, G.F. 2007. Organizations and organizing: Rational, natural, and open system perspectives. Upper Saddle River, NJ: Pearson Prentice Hall.

Short, J. C., Ketchen, J. J., Shook, C. L., \& Ireland, R. D. 2010. The concept of "opportunity" in entrepreneurship research: Past accomplishments and future challenges. Journal Of Management, 36(1): 40-65.

Smith, A. 1776/2003. The wealth of nations (new title edition). New York, NY: Bantham Classics.

SpaceX, 2015. http://www.spacex.com/about, accessed July 242015. 
SpaceX. 2017. SpaceX to send privately crewed Dragon Spacecraft beyond moon next year. February 27. http://www.spacex.com/news/2017/02/27/spacex-sendprivately-crewed-dragon-spacecraft-beyond-moon-next-year

Stone, R. L. 2011. The everything store: Jeff Bezos and the age of Amazon. New York, NY: Little, Brown and Company.

Summers-Effler, E. 2002. The micro potential for social change: Emotion, consciousness and social movement formation. Sociological Theory, 20: 41-60.

Tedmanson, D., Essers, C., Dey, P., \& Verduyn, K. 2015. An uncommon wealth . . .Transforming the commons with purpose, for people and not for profit!. Journal Of Management Inquiry, 24(4): 439-444.

Thomas, L. D. W., Autio, E., \& Gann, D. M. 2014. Architectural leverage: Putting platforms in context. Academy of Management Perspectives, 28(2): 198-219

Tobias, J. M., Mair, J., \& Barbosa-Leiker, C. 2013. Toward a theory of transformative entrepreneuring: Poverty reduction and conflict resolution in Rwanda's entrepreneurial coffee sector. Journal Of Business Venturing, 28(6): 728-742.

Van de Ven, A. H. 2007. Engaged scholarship: A guide for organizational and social research. New York, NY: Oxford University Press.

Van de Ven, A. H., Polley, D. E., Garud, R. \& Venkataraman, S. 1999. The innovation journey. New York, NY: Oxford University Press.

van Werven, R., Bouwmeester, O., \& Cornelissen, J. P. 2015. The power of arguments: How entrepreneurs convince stakeholders of the legitimate distinctiveness of their ventures. Journal Of Business Venturing, 30(4): 616-631.

Vance, A. 2015. Elon Musk: Tesla, SpaceX, and the quest for a fantastic future. New York, Harper Collins.

Verduijn, K., \& Essers, C. 2013. Questioning dominant entrepreneurship assumptions: the case of female ethnic minority entrepreneurs. Entrepreneurship \& Regional Development, 25(7/8), 612-630..

Virgin Galactic, 2015. http://www.virgingalactic.com/our-vision-of-the-future/, accessed July 24, 2015.

von Hippel, E. 2005. Democratizing innovation. Boston, MA: MIT Press.

von Krogh, G., Haefliger, S., Spaeth, S., \& Wallin, M. W. 2012. Carrots and rainbows: Motivation and social practice in open source software development. MIS Quarterly, 36(2): 649-676. 
Webb, J., Ireland, R., Hitt, M., Kistruck, G., \& Tihanyi, L. 2011. Where is the opportunity without the customer? An integration of marketing activities, the entrepreneurship process, and institutional theory. Journal Of The Academy Of Marketing Science, 39(4): 537-554.

Webb, J. W., Tihanyi, L, Ireland, R. D., \& Sirmon, D. G. 2009. You say illegal, I say legitimate: Entrepreneurship in the informal economy. Academy Of Management Review, 34(3): 492-510.

Weber, S. 2004. The success of open source. Boston, MA: Harvard University Press.

Williamson, O. E. 1975. Markets and hierarchies: Analysis and antitrust implications. New York, NY: Free Press.

Williamson, O. E. 1981. The economics of organization: The transaction cost approach. The American Journal of Sociology, 87(3): 548-577.

Yin, R. K. 2011. Qualitative research from start to finish. New York, NY: Guilford Press.

Yin, R. K. 2014. Case study research: Design and methods ( $5^{\text {th }}$ edition). Thousand Oaks, CA: Sage Publications.

\subsection{Websites}

Bigelow Aerospace

Blue Origin

International Space University

Peter Diamandis

Planetary Resources

QSR International

Scaled Composites

Singularity University

Space Adventures Limited

SpaceX

The Spaceship Company

Virgin Galactic

XPRIZE

Zero Gravity Corporation https://bigelowaerospace.com

https://blueorigin.com

http://www.isunet.edu

http://www.diamandis.com/

http://www.planetaryresources.com

https://qsrinternational.com

http://www.scaled.com

https://su.org

http://www.spaceadventures.com

http://www.spacex.com

http://thespaceshipcompany.com

http://www.virgingalactic.com

https://www.xprize.org

https://www.gozerog.com 
Emancipated entrepreneuring in the nascent commercial spaceflight industry:

Authoring ecosystems by Branson, Diamandis, and Musk. Copyright (C) 2018 Ewan Reid

\section{Appendix: Operational specification}

This appendix presents version 3 of the operational specification for an event study using the emancipation perspective on entrepreneuring (Rindova et al. 2009).

The specification developed here returns to the original definitions of Rindova et al. (2009), draws on additional conceptual and empirical work from other sources, and benefits from the insights of two coding pilots, each comprised of multiple activities.

\subsection{Background}

We begin by borrowing several ideas and definitions of terms from the methodology literature of process theory event studies (Van de Ven et al. 1999; Poole et al. 2000; Van de Ven, 2007):

1. Abbot (1984) distinguishes between an incident (a raw datum) and an event (a theoretical construct).

2. Poole et al. (2000) defines a qualitative datum for an incident as "(1) a bracketed string of words capturing the basic elements of information (2) about a discrete incident or occurrence (the unit of analysis) (3) that happened on a specific date, which is (4) entered as a unique record (or case) in a qualitative data file, and (5) is subsequently coded and classified as an indicator of a theoretical event." (p. 133).

3. Poole et al. (2000) argues for a common framework to describe events (p. 49) with systematic coding rules that specify the operational steps for classifying incidents into event constructs (p. 163). 
4. Poole et al. (2000) argues for construction of a data file that systematically presents the events that were observed to occur in the organizational entities being investigated (p. 113).

\subsection{Events}

Emancipation events are of three types, corresponding to the three core elements of the Rindova et al. (2007) emancipatory perspective on entrepreneuring: (1) seeking autonomy, (2) authoring, and (3), making declarations.

Seeking autonomy refers to both breaking free of perceived constraints and also breaking up the perceived constraints, which can be intellectual, psychological, economic, institutional, or cultural. Seeking autonomy can be an impetus of entrepreneuring.

Authoring refers to taking ownership by defining relationships, arrangements, and rules of engagement, and changing the positions of power. Authoring reorganizes resource exchanges by positioning the entrepreneurial project in a system of exchange relationships with resource holders.

Making declarations refers to unambiguous discursive and rhetorical acts regarding the actor's intentions to create change. Making declarations manages stakeholder interpretations by positioning the entrepreneurial project in the webs of meaning within which stakeholders interpret the value of products and activities.

\subsection{Common framework}

The common framework for describing an event of each type is as follows:

- Seeking autonomy (SA) has three event attributes: (1) the perceived constraint, 
(2) breaking free of the perceived constraint (including dreams, desire, passion, intent, and actions), (3) breaking up the perceived constraint. The first attribute, and at least one of the second and third attributes, are required.

- Authoring (A) has two event attributes: (1) the old status quo to be changed (including relationships, arrangements, norms, rules of engagement, positions of power, and forms of authority), (2) the new arrangement supporting the changecreating intent of the entrepreneuring individual. Both attributes are required.

- Making declarations (MD) has four event attributes: (1) statement of intent to create change, (2) forms of discursive or rhetorical acts, (3) contestations from others, (4) overcoming contestations from others. The first attributes are required.

- Each event of all three event types also references the incidents that indicate the event. This maintains the traceable chain of evidence back to the original source material

- An event can be related to other events; the description of events of each event type may also include relationships to other events

- Each event is identified by a unique name, beginning with the entrepreneur, then the event type, then a number, and sequenced chronologically.

- E.g., Musk-SA-01 for the first seeking autonomy event of Elon Musk, or Diamandis-A-02 for the second authoring event of Peter Diamandis.

- Event numbers are normally sequenced chronologically in time within each category, beginning with the earliest event to occur. 
Chapter 8: Appendix: Operational specification

\subsection{Incidents and the qualitative datum}

Events are indicated by incidents - coded passages of text from primary sources. The qualitative datum for an incident is a referenced passage of text, formally specified as a bracketed string of words about an occurrence of emancipation, excerpted from a source, with a reference to the source and the location of the words within the source. Incidents are subsequently re-coded and classified into emancipation events

\subsection{Data file}

The data file is an NVivo project that includes the primary sources, additional supporting sources, incident codes assigned to passages of text, case codes for each entrepreneur, event cases with attributes, and memos.

\subsection{Coding}

There are three rounds of coding:

- An initial round of incident coding assigns incident codes to passages of text in the primary sources (i.e., the qualitative data for incidents). Each incident code is an Nvivo node organized in a hierarchical coding structure.

- A second round of event coding assigns incidents to events. Each event is an NVivo case node. Incidents are re-coded to one or more event case nodes. Each event is specified in a linked case node memo following the common framework for describing an event.

- A third round of organizational form coding assigns organizational form attributes to each event. An event case node can be assigned one or more of the following organizational forms: (1) hierarchy, (2) market, or (3) ecosystem. 
There are two possible codes for each organizational form, indicating the strength of association - (a) evident, or (b) strongly evident - for a total of six possible organizational form codes.

\subsection{Incident codes}

Normally assign codes at the lowest level appropriate for an incident.

Add to ad hoc codes as required.

- Emancipation

- Seeking autonomy

- Perceived constraint

- Break free or break up

- Authoring

- Old status quo

- New arrangement

- Making declarations

- Statement of intent to create change

- Forms

- Contestations

- Overcoming contestations

- Actors

- Companies

- Blue Origin

- Google

- Virgin Group companies

- People

- Bezos

- Russians

- Space agencies

- ESA

- NASA

- Funding

- Contracts from NASA

- Crowdfunding

- Private funding

- Systems

- ISS

- NASA systems

- Apollo 
- Russian systems

- ICBMs

- Soyuz capsule

- Soyuz rocket

- SpaceX systems

- Rockets

- Falcon 1

- Falcon 5

- Falcon 9

- Falcon Heavy

- Spacecraft

- Dragon

- Dragon 2 (crewed)

- XPRIZE systems

- GLXP

- Ad hoc codes (add as needed)

- Dyslecia

- Exponential entrepreneur

○ Fun

- Mars

- Moon

- Praise by others

- The Virgin Way 